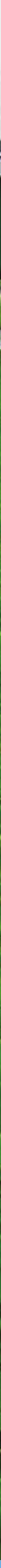

\title{
Nitrous oxide emission from agricultural soils
}

G.L. Velthof and R.P.J.J. Rietra 



\section{Nitrous oxide emission from agricultural soils}

G.L. Velthof and R.P.J.J. Rietra 
G.L. Velthof and R.P.J.J. Rietra, 2018. Nitrous oxide emission from agricultural soils. Wageningen, Wageningen Environmental Research, Report 2921. 58 pp.; 23 fig.; 19 tab.; 166 ref.

Lachgas $\left(\mathrm{N}_{2} \mathrm{O}\right)$ is een broeikasgas met op mondiaal niveau een aandeel van $6 \%$ in de emissies van broeikasgassen. Bemeste landbouwgronden zijn een belangrijke bron van $\mathrm{N}_{2} \mathrm{O}$. Er is een literatuurstudie uitgevoerd naar $\mathrm{N}_{2} \mathrm{O}$-emissie uit landbouwgronden met focus op de emissie uit verschillende typen kunstmest en de mogelijkheden om de emissie uit kunstmest te beperken. De $\mathrm{N}_{2} \mathrm{O}$-emissie uit kunstmest draagt voor $0,8 \%$ bij aan de totale broeikasgasemissie in Nederland. Uit de literatuur volgt dat toediening van kunstmest onder gemiddelde en relatief droge omstandigheden in de bodem leidt tot een beperkt risico op $\mathrm{N}_{2} \mathrm{O}$-emissie voor zowel grasland als bouwland. Het risico op $\mathrm{N}_{2} \mathrm{O}$-emissie neemt toe als nitraathoudende kunstmeststoffen, zoals kalkammonsalpeter en urean, onder natte omstandigheden aan grasland (alle grondsoorten) en bouwland (met name klei- en veengrond) worden toegediend. Het toedienen van een ammoniummeststof (eventueel met nitrificatieremmer) of ureum onder natte omstandigheden of het uitstellen van bemesting van de nitraathoudende kunstmest tot drogere omstandigheden zijn mogelijkheden om $\mathrm{N}_{2} \mathrm{O}$-emissie te beperken. De zogenaamde 4R-strategie om de benutting van nutriënten uit meststoffen te verhogen, kan ook leiden tot een lagere $\mathrm{N}_{2} \mathrm{O}$-emissie, namelijk $\mathrm{N}$-toediening met het juiste type, juiste hoeveelheid, juiste tijdstip en juiste plaats.

Nitrous oxide $\left(\mathrm{N}_{2} \mathrm{O}\right)$ is a greenhouse gas contributing to $6 \%$ of the global greenhouse effect. Fertilized agricultural soils are a major source of $\mathrm{N}_{2} \mathrm{O}$. A literature study on $\mathrm{N}_{2} \mathrm{O}$ emission from agricultural soils was carried out focussing on the effect of different types of mineral nitrogen $(\mathrm{N})$ fertilizers and strategies to mitigate $\mathrm{N}_{2} \mathrm{O}$ emission from fertilizers. The $\mathrm{N}_{2} \mathrm{O}$ emission from mineral $\mathrm{N}$ fertilizer application contributes to $0.8 \%$ of the total greenhouse gas emission in the Netherlands. The study shows that application of mineral $\mathrm{N}$ fertilizer under moderate and relatively dry conditions results in a relatively low risk of $\mathrm{N}_{2} \mathrm{O}$ emission from both grassland and arable land. However, during wet conditions, application of nitrate containing mineral fertilizers such as (calcium) ammonium nitrate and urean to grasslands (all soil types) and arable crops on clay and peat soils increases the risk of $\mathrm{N}_{2} \mathrm{O}$ emission. To decrease the risk of $\mathrm{N}_{2} \mathrm{O}$ emission during wet conditions, an ammonium based fertilizer (possibly with a nitrification inhibitor) or urea can be used. Alternatively, the application of nitrate based fertilizer should be postponed until drier periods. The $4 \mathrm{R}$ strategy to increase nutrient use efficiency of fertilizers will also reduce $\mathrm{N}_{2} \mathrm{O}$ emission, i.e., $\mathrm{N}$ application with the Right type, at the Right rate, at the Right time, and in the Right place.

Keywords: agriculture, emission, mineral fertilizer, manure, nitrous oxide, soils

The pdf file is free of charge and can be downloaded at https://doi.org/10.18174/466362 or via the website www.wur.nl/environmental-research (scroll down to Publications - Wageningen Environmental Research reports). Wageningen Environmental Research does not deliver printed versions of the Wageningen Environmental Research reports.

2018 Wageningen Environmental Research (an institute under the auspices of the Stichting Wageningen Research), P.O. Box 47, 6700 AA Wageningen, The Netherlands, $\mathrm{T}+31$ (0)317 4807 00, www.wur.nl/environmental-research. Wageningen Environmental Research is part of Wageningen University \& Research.

- Acquisition, duplication and transmission of this publication is permitted with clear acknowledgement of the source.

- Acquisition, duplication and transmission is not permitted for commercial purposes and/or monetary gain.

- Acquisition, duplication and transmission is not permitted of any parts of this publication for which the copyrights clearly rest with other parties and/or are reserved.

Wageningen Environmental Research assumes no liability for any losses resulting from the use of the research results or recommendations in this report.

Wageningen Environmental Research Report 2921 | ISSN 1566-7197

Photo cover: Eduard Hummelink 


\section{Contents}

Summary $\quad 5$

$\begin{array}{llr}1 & \text { Introduction } & 9\end{array}$

$2 \quad$ Nitrous oxide $r$

$\begin{array}{lll}2.1 & \text { Nitrous oxide } & 10\end{array}$

2.2 Sources of nitrous oxide $\quad 11$

2.2.1 Global 11

2.2.2 The Netherlands 13

2.3 Monitoring 16

2.3.1 Intergovernmental Panel on Climate Change (IPCC) 16

2.3.2 The Netherlands 16

Processes and controlling factors $\quad 19$

3.1 Processes 19

3.1 .1 Nitrification 19

3.1 .2 Denitrification 19

3.1.3 Nitrifier denitrification $\quad 21$

$\begin{array}{lll}3.2 & \text { Controlling factors } & 21\end{array}$

3.2.1 Nitrogen type and concentration $\quad 22$

3.2.2 Carbon/organic matter $\quad 23$

3.2.3 Moisture content and aeration $\quad 24$

$\begin{array}{ll}3.2 .4 \text { Temperature } & 25\end{array}$

$\begin{array}{ll}3.2 .5 \mathrm{pH} & 25\end{array}$

$\begin{array}{ll}3.2 .6 & \text { Soil type and structure }\end{array}$

$\begin{array}{ll}3.2 .7 & \text { Interactions between factors } \\ & 25\end{array}$

4 Agricultural value of nitrogen fertilizers and manures $\quad 26$

4.1 Nitrogen use efficiency of mineral fertilizer types 26

$\begin{array}{lll}4.2 & \text { Nitrogen use efficiency of manures } & 28\end{array}$

$\begin{array}{lll}4.3 & \text { Acidification } & 28\end{array}$

$\begin{array}{lll}4.4 & \text { Conclusions } & 30\end{array}$

$5 \quad$ Effects of mineral fertilizers and manures on nitrous oxide emission 31

5.1 Studies with different fertilizer types in the Netherlands 31

5.1.1 Field experiments 31

$\begin{array}{ll}5.1 .2 \text { Laboratory experiments } & 34\end{array}$

$\begin{array}{lll}5.2 & \text { Studies outside the Netherlands } & 36\end{array}$

$\begin{array}{lll}5.3 & \text { Synthesis } & 38\end{array}$

6 Mitigation of nitrous oxide emission from fertilizers and manures 40

$\begin{array}{lll}6.1 & \text { Nitrification inhibitors } & 40\end{array}$

6.1.1 Types of nitrification inhibitor $\quad 40$

6.1.2 Effect on $\mathrm{N}_{2} \mathrm{O}$ emission $\quad 42$

$\begin{array}{lll}6.2 & \text { Denitrification inhibitors } & 44\end{array}$

$\begin{array}{lll}6.3 & \text { Slow release fertilizers } & 45\end{array}$

$\begin{array}{lll}6.4 & \text { Nutrient management } & 45\end{array}$

$\begin{array}{ll}6.4 .1 & \text { Right type } \\ 6.4 .2 & 45\end{array}$

6.4.2 Right rate $\quad 46$

6.4.3 Right time $\quad 46$

6.4.4 Right Place $\quad 47$

$\begin{array}{ll}\text { References } & \mathbf{4 8}\end{array}$ 



\section{Summary}

OCI Nitrogen BV has requested that Wageningen Environmental Research carry out a literature study on nitrous oxide $\left(\mathrm{N}_{2} \mathrm{O}\right)$ emission from agricultural soils that focusses on the effect of different types of mineral $\mathrm{N}$ fertilizers and strategies to mitigate $\mathrm{N}_{2} \mathrm{O}$ emission from fertilizers.

Concentrations of atmospheric $\mathrm{N}_{2} \mathrm{O}$ have risen from $270 \pm 7$ ppb in 1750 to $324.2 \pm 0.1$ ppb in 2011 . It is estimated that $30 \%$ of the $\mathrm{N}_{2} \mathrm{O}$ in the atmosphere is the result of human activity mainly originating from agricultural sources. Nitrous oxide is a greenhouse gas that currently contributes to $6 \%$ of total radiative forcing. $\mathrm{CO}_{2}$ contributes to $75 \%$ and methane $\left(\mathrm{CH}_{4}\right)$ to $17 \%$ of this total figure. Agriculture accounts for approximately $75 \%$ of total $\mathrm{N}_{2} \mathrm{O}$ emissions. The dominant global sources of $\mathrm{N}_{2} \mathrm{O}$ emissions are manure application to grasslands (22\%) and synthetic fertilizers (18\%). Nitrous oxide also depletes stratospheric ozone and $\mathrm{N}_{2} \mathrm{O}$ emission is currently the single most important ozone depleting emission. It is expected that $\mathrm{N}_{2} \mathrm{O}$ will remain the largest ozone depleting emission throughout the 21 st century.

In the Netherlands, $\mathrm{N}_{2} \mathrm{O}$ emission from agriculture contributes 6.1 Mton $\mathrm{CO}_{2}$ equivalents or $3.1 \%$ of the total greenhouse gas emissions. The emission of $\mathrm{N}_{2} \mathrm{O}$ from agriculture amounts to $74 \%$ of the total $\mathrm{N}_{2} \mathrm{O}$ emission in the Netherlands. The $\mathrm{N}_{2} \mathrm{O}$ emission from mineral fertilizer applied to agricultural soils amounts to 1.6 Mton $\mathrm{CO}_{2}$-equivalents or $0.8 \%$ of the total greenhouse gas emission and $19.7 \%$ of the total $\mathrm{N}_{2} \mathrm{O}$ emission in the Netherlands. Since 1990, a sharp reduction of $\mathrm{N}_{2} \mathrm{O}$ emission from agriculture and industrial processes (i.e. nitrate fertilizer production) has resulted in a strong decrease in nitrous oxide emission in the Netherlands. The decrease of $\mathrm{N}_{2} \mathrm{O}$ emission from agricultural soils in the Netherlands since 1990 can be attributed to the manure policy which has led to a decrease in the amount nitrogen ( $\mathrm{N}$ ) applied to soils, nitrate leaching, and ammonia emission. The $\mathrm{N}_{2} \mathrm{O}$ emission from mineral $\mathrm{N}$ fertilizer decreased by 0.9 Mton (more than 30\%) between 1990 and 2015. In the early nineties, the introduction of rules to abate ammonia emission required the injection of slurry into agricultural soil resulting in an increase of $\mathrm{N}_{2} \mathrm{O}$ emission from livestock manure.

The main sources of $\mathrm{N}_{2} \mathrm{O}$ production in soils are nitrification, denitrification, nitrifier denitrification and chemical denitrification. Soil type and conditions, weather conditions, and $\mathrm{N}$ management have a large effect on the $\mathrm{N}_{2} \mathrm{O}$ producing soil processes. Rapid changes in soil mineral $\mathrm{N}$ contents (e.g. through application of fertilizers and manure), available carbon contents in soil (e.g. through application of crop residues and manure), oxygen concentrations (e.g. through rainfall, groundwater fluctuations, and biological oxygen consumption in the soil) and temperature induce strong fluctuations in $\mathrm{N}_{2} \mathrm{O}$ emission. Highest $\mathrm{N}_{2} \mathrm{O}$ production is found in fertilized soils during relatively wet soil conditions, especially in soils rich in organic matter (e.g. grassland soils, peat soils or soils to which organic matter is applied). There are also many interactions between controlling variables that affect $\mathrm{N}_{2} \mathrm{O}$ emission. The many variables and interactions between these make the overall effect on $\mathrm{N}_{2} \mathrm{O}$ emission difficult to predict. Analysis of the dataset of emission factors in the Netherlands led to the use of country specific emission factors for mineral fertilizers, i.e., $0.8 \%$ of the fertilizer $\mathrm{N}$ applied for mineral soils and $3.0 \%$ of the fertilizer $\mathrm{N}$ applied for peat soils.

Statistical analyses of data contained within the global database with measurements of $\mathrm{N}_{2} \mathrm{O}$ emissions showed no significant effect of fertilizer type on $\mathrm{N}_{2} \mathrm{O}$ emission. However, several studies in which different mineral fertilizers are compared often show differences. Studies on grassland soils point to higher $\mathrm{N}_{2} \mathrm{O}$ emissions from nitrate based fertilizers than from fertilizers only containing ammonium, especially during wet conditions. The denitrification capacity of grassland is high because of the high organic matter contents. Adding nitrate to grassland during wet conditions or before rainfall events increases the risk of high $\mathrm{N}_{2} \mathrm{O}$ emission. Studies on arable soils point to similar or lower $\mathrm{N}_{2} \mathrm{O}$ emissions from nitrate based fertilizers than urea and ammonium based fertilizers, especially under relatively dry conditions. Urea may increase $\mathrm{N}_{2} \mathrm{O}$ emission during relatively dry conditions because of ammonia toxicity in nitrifying bacteria resulting in accumulation of nitrite $\left(\mathrm{NO}_{2}^{-}\right)$and increased $\mathrm{N}_{2} \mathrm{O}$ production. 
The denitrification capacity of arable land is low and lower than that of grasslands because of the low organic matter content. Application of livestock slurry increases the denitrification capacity of arable land. The emission of $\mathrm{N}_{2} \mathrm{O}$ from arable land is higher for livestock slurry than for calcium ammonium nitrate application. The differences between different fertilizer types on $\mathrm{N}_{2} \mathrm{O}$ emission are not included in the Dutch monitoring protocol (all fertilizers have the same emission factor). However, it may be expected that the strict targets for reducing greenhouse gas emissions will result in the inclusion of the effect of different nutrient management strategies in protocols. The 4R strategy to increase nutrient use efficiency of fertilizers will also reduce $\mathrm{N}_{2} \mathrm{O}$ emission, i.e., $\mathrm{N}$ application with the Right type, at the Right rate, at the Right time, and in the Right place.

\section{Right type}

Results from literature show that the $\mathrm{N}$ use efficiency of (calcium) ammonium nitrate is on average higher than that of regular urea and ammonium based fertilizers. This is mainly due to higher ammonia losses from urea and ammonium based fertilizers compared to nitrate containing fertilizers. Adding a urease inhibitor to urea decreases the risk of ammonia emission. Ammonium nitrate fertilizer application results in less acidification of the soil than ammonium and urea fertilizer application which is beneficial for crop quality and the species composition of grassland, and results in less demand for lime. Soil acidification may also increase the risk of $\mathrm{N}_{2} \mathrm{O}$ emission when using ammonium and urea based fertilizers relative to (calcium) ammonium nitrate application.

Emission of $\mathrm{N}_{2} \mathrm{O}$ from urea and ammonium fertilizers on arable soils is similar to or higher than that of nitrate fertilizers. Nitrous oxide emission from manure on arable sandy soils is much higher than that of mineral $\mathrm{N}$ fertilizers probably due to an increase in the denitrification capacity of the soil resulting from the organic matter content of manure. Nitrate fertilizer should not be applied just after manure application because the fresh organic matter of the manure can increase $\mathrm{N}_{2} \mathrm{O}$ emission from the applied nitrate.

Application of nitrate fertilizer should be avoided on soils with a high denitrification capacity (high amounts of easily available organic matter) during wet conditions or just before expected heavy rainfall. These include grasslands, peat soils and arable land on clay soils. Options to decrease $\mathrm{N}_{2} \mathrm{O}$ emission during these conditions include postponing the application of nitrate fertilizer or applying an ammonium fertilizer or livestock slurry during wet conditions. Grassland can rapidly absorb N, especially in late spring, summer and early autumn, and mineral $\mathrm{N}$ contents will decrease over a number of days following $\mathrm{N}$ application. Thus, the longer the period without rainfall following nitrate application, the lower the risk of $\mathrm{N}_{2} \mathrm{O}$ emission.

The use of ammonium based fertilizers with a nitrification inhibitor can further reduce $\mathrm{N}_{2} \mathrm{O}$ emission. The most well-known inhibitors, DCD, and DMPP can reduce $\mathrm{N}_{2} \mathrm{O}$ emission by approximately 30 to $50 \%$, with the highest effects seen in grassland. Addition of a nitrification inhibitor may also decrease $\mathrm{N}_{2} \mathrm{O}$ emission from ammonium nitrate fertilizer, but it is doubtful whether $\mathrm{N}_{2} \mathrm{O}$ emission can be heavily reduced during wet conditions when denitrification activity is high. Although several compounds may have inhibitory effects on denitrification, there are, unlike nitrification inhibitors, no commercial denitrification inhibitors available. Compounds that may have some inhibitory denitrification effects include heavy metals, salts and organic compounds. However, it is not known whether these compounds maybe used as denitrification inhibitors as their mode of action and specificity are currently unclear.

\section{Right rate}

The fertilizer application rate should be balanced with the $\mathrm{N}$ requirement of the crop as over fertilization increases the risk of $\mathrm{N}_{2} \mathrm{O}$ emission. If manure or other organic fertilizers are used, the amount of available $\mathrm{N}$ should be accounted for in the application of mineral $\mathrm{N}$ fertilizer. Separating $\mathrm{N}$ fertilization into several applications limits overall mineral $\mathrm{N}$ content in the soil and reduces periods of elevated mineral $\mathrm{N}$ content, decreasing the risk of $\mathrm{N}_{2} \mathrm{O}$ emission. In wet periods on grasslands, separating the recommended $\mathrm{N}$ fertilization into smaller applications may decrease $\mathrm{N}_{2} \mathrm{O}$ emission. 


\section{Right time}

The risk of $\mathrm{N}_{2} \mathrm{O}$ emission is highest when the mineral $\mathrm{N}$ content of the soil is elevated. Therefore, shortening the period of elevated soil mineral $\mathrm{N}$ contents after fertilizer or manure application decreases the risk of $\mathrm{N}_{2} \mathrm{O}$ emission. Therefore, $\mathrm{N}$ should be applied during or just before the crop growing period. The risk of $\mathrm{N}_{2} \mathrm{O}$ emission increases when the moisture content of the soil increases for both ammonium, urea, and nitrate based fertilizers. Grasslands and peat soils have a high denitrification capacity, i.e., they contain easily available organic matter. Application of a nitrate fertilizer to these soil types during wet conditions should be avoided because of the high risk of $\mathrm{N}_{2} \mathrm{O}$ emission. An ammonium based fertilizer (possibly with a nitrification inhibitor) can be used to decrease the risk of $\mathrm{N}_{2} \mathrm{O}$ emission during wet conditions or the application of the nitrate based fertilizer can be postponed to drier periods.

Application of manures, regular urea and urean (a solution of urea and ammonium nitrate) and the application of ammonium fertilizer to calcareous soils result in a risk of ammonia emission which decreases the $\mathrm{N}$ use efficiency of these fertilizers. Application during rainy conditions decrease the risk of ammonia emission. However, application of fertilizers and manures during rainy conditions will increase the risk of $\mathrm{N}_{2} \mathrm{O}$ emission. Large losses of ammonia decrease the $\mathrm{N}$ use efficiency and, depending on the $\mathrm{N}$ application rate, increase the need for additional $\mathrm{N}$ fertilizers which heightens the risk of nitrate leaching. Ammonia is also a source of indirect $\mathrm{N}_{2} \mathrm{O}$ emission meaning that a reduction in ammonia emission will also reduce $\mathrm{N}_{2} \mathrm{O}$ emission.

\section{Right Place}

Surface application of fertilizers and manures decreases $\mathrm{N}_{2} \mathrm{O}$ emission relative to incorporation or injection methods. Surface application increases the risk of ammonia emission, however, the risk of ammonia emission for calcium ammonium nitrate is much smaller than for regular urea, urean, livestock manure and ammonium fertilizers (when applied to calcareous soils). Ammonia is also a source of indirect $\mathrm{N}_{2} \mathrm{O}$ emission meaning that ammonia emission reduction will also reduce $\mathrm{N}_{2} \mathrm{O}$ emission. 


\section{Introduction}

Nitrous oxide $\left(\mathrm{N}_{2} \mathrm{O}\right)$ is a greenhouse gas that is also harmful to stratospheric ozone (depletion of the ozone layer). Fertilized soils are a major source of $\mathrm{N}_{2} \mathrm{O}$.

OCI Nitrogen BV has requested that Wageningen Environmental Research carry out a literature study on $\mathrm{N}_{2} \mathrm{O}$ emission from agricultural soils. Topics to be included in this study are:

- A description of the mechanisms of $\mathrm{N}_{2} \mathrm{O}$ production in soils;

- A description of the factors controlling $\mathrm{N}_{2} \mathrm{O}$ emission from soils, including the effect of nitrogen $(\mathrm{N})$;

- An overview of the $\mathrm{N}_{2} \mathrm{O}$ emission from different types of mineral $\mathrm{N}$ fertilizers and animal manure;

- Options to mitigate $\mathrm{N}_{2} \mathrm{O}$ emission from agricultural soils; and

- An overview of nitrification and denitrification inhibitors and their effectiveness in decreasing $\mathrm{N}_{2} \mathrm{O}$ emission.

Chapter 2 gives an overview of the Global Warming Potential of $\mathrm{N}_{2} \mathrm{O}$, the main $\mathrm{N}_{2} \mathrm{O}$ sources, and monitoring of $\mathrm{N}_{2} \mathrm{O}$ emission. Chapter 3 describes the processes of the variables influencing $\mathrm{N}_{2} \mathrm{O}$ emission from agricultural soils, Chapter 4 deals with the agricultural value of $\mathrm{N}$ fertilizers and manures, Chapter 5 provides an overview of the effects of mineral fertilizers and manures on $\mathrm{N}_{2} \mathrm{O}$ emission, and Chapter 6 includes options for mitigation of $\mathrm{N}_{2} \mathrm{O}$ emission from fertilizers and manures, including the use of inhibitors. 


\section{Nitrous oxide}

\section{$2.1 \quad$ Nitrous oxide}

Nitrous oxide ( $\mathrm{N}_{2} \mathrm{O}$; popular name laughing gas) is a colourless non-flammable gas. It is a natural gas that occurs in small amounts ( $\pm 300 \mu \mathrm{g}$ per $\mathrm{L}$ or $\mathrm{ppb}$ ) in the atmosphere. Nitrous oxide is also used in surgery because it has anaesthetic and pain reducing effects. It is also used as an oxidizer to increase the power of engines.

Atmospheric concentrations of nitrous oxide have risen from $270 \pm 7 \mathrm{ppb}$ in 1750 to $324.2 \pm 0.1 \mathrm{ppb}$ in 2011 (IPCC, 2013. See Figure 1 for the trend in concentration from 1978 to 2011). It is estimated that $30 \%$ of the $\mathrm{N}_{2} \mathrm{O}$ in the atmosphere is the result of human activity which is mainly attributed to agriculture (IPCC, 2013).

Nitrous oxide is a greenhouse gas. The Global Warming Potential (GWP) is used to compare the global warming impacts of different gases. The GWP indicates how much energy the emissions of 1 ton of a gas will absorb over a given period of time, relative to the emissions of 1 ton of carbon dioxide $\left(\mathrm{CO}_{2}\right)$. The GWP depends on the absorption of infrared radiation by a given species, the spectral location of its absorbing wavelengths, and the atmospheric lifetime of the species. Nitrous oxide has a GWP 265 times that of $\mathrm{CO}_{2}$ over a 100 year timescale (IPCC, 2013 ${ }^{1}$ ) because of its long residence time (121 years) and strong absorption capacity (for comparison, methane has a GWP of 28).

The concentration of $\mathrm{N}_{2} \mathrm{O}$ is much smaller (measured in $\mathrm{ppb}$ ) than $\mathrm{CO}_{2}$ (measured in ppm) and therefore the total greenhouse effect of $\mathrm{N}_{2} \mathrm{O}$ is much smaller than that of $\mathrm{CO}_{2}$. The radiative forcing ${ }^{2}$ of $\mathrm{N}_{2} \mathrm{O}$ is currently $0.17 \pm 0.03 \mathrm{~W} \mathrm{~m}^{-2}$ ( $6 \%$ of total radiative forcing; IPCC, 2013). The radiative forcing of $\mathrm{CO}_{2}$ is $1.82 \pm 0.19(64 \%)$ and that of $\mathrm{CH}_{4} 0.48 \pm 0.05 \mathrm{~W} \mathrm{~m}^{-2}(17 \%)$.

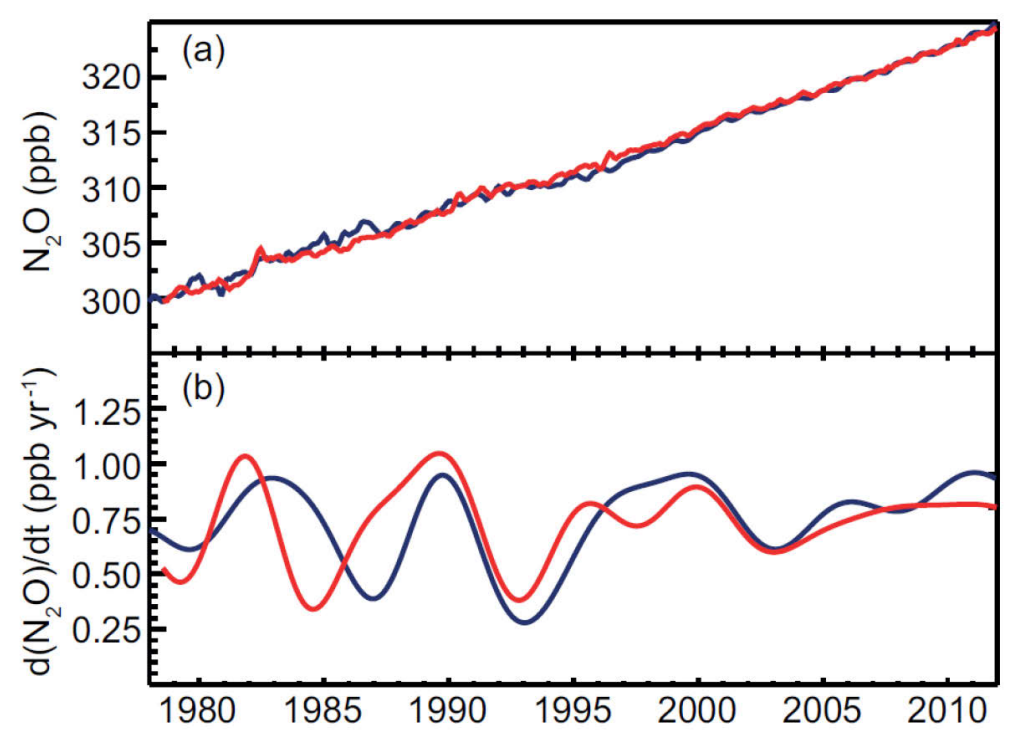

Figure 1 a) Globally averaged $\mathrm{N}_{2} \mathrm{O}$ dry-air mole fractions from AGAGE (red) and NOAA/ESRL/GMD (blue) stations at monthly resolution. (b) Instantaneous growth rates for globally averaged atmospheric $\mathrm{N}_{2} \mathrm{O}$ (IPCC, 2013).

\footnotetext{
1 The GWP of $\mathrm{N}_{2} \mathrm{O}$ was 298 for a 100 year timescale according to the IPCC (2007).

2 IPCC: 'Radiative forcing is a measure of the influence a factor has in altering the balance of incoming and outgoing energy in the Earth-atmosphere system and is an index of the importance of the factor as a potential climate change mechanism. In this report radiative forcing values are for changes relative to preindustrial conditions defined at 1750 and are expressed in Watts per square meter $\left(\mathrm{W} / \mathrm{m}^{2}\right)$.'
} 
$\mathrm{N}_{2} \mathrm{O}$ is also a stratospheric ozone depleting gas (Figure 2). Emissions of chlorofluorocarbons (CFCs) have strongly decreased because of the Montreal Protocol and signs of ozone stabilization have been observed. Currently, $\mathrm{N}_{2} \mathrm{O}$ emission is the single most important ozone depleting emission and is expected to remain the most important throughout the 21st century (Ravishankara et al., 2009; Wuebbles, 2009).

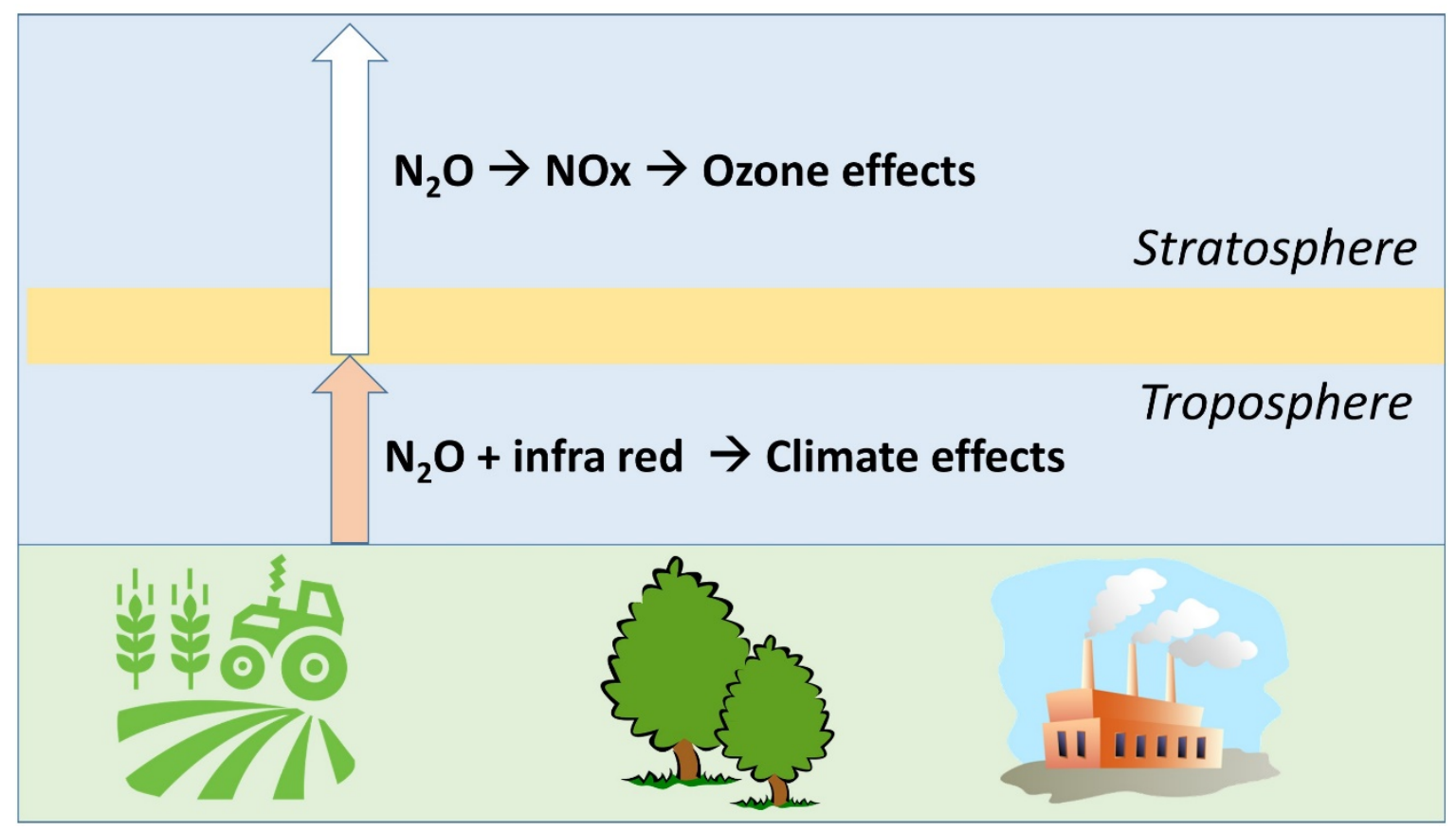

Figure 2 Nitrous oxide is a greenhouse gas (troposphere) and ozone depleting gas (stratosphere) (After Wuebbles, 2009).

\subsection{Sources of nitrous oxide}

\subsubsection{Global}

Nitrous oxide emissions account for about $6 \%$ of total greenhouse gas emissions on a global scale (Figure 3). Agriculture, including indirect $\mathrm{N}_{2} \mathrm{O}$ emissions ${ }^{3}$, accounts for about $75 \%$ of total $\mathrm{N}_{2} \mathrm{O}$ emissions (Figure 3).

The main global sources of $\mathrm{N}_{2} \mathrm{O}$ emissions are manure application to grasslands (pastures, rangeland and paddocks) and synthetic fertilizers (22\% and $18 \%$, respectively in 2016; Figure 4).

\footnotetext{
3 Indirect $\mathrm{N}_{2} \mathrm{O}$ emissions are emissions of $\mathrm{N}_{2} \mathrm{O}$ from volatilized ammonia $\left(\mathrm{NH}_{3}\right)$ and leached nitrate $\left(\mathrm{NO}_{3}{ }^{-}\right)$.
} 


\section{Contribution to 2016 greenhouse gas emissions per emission category}

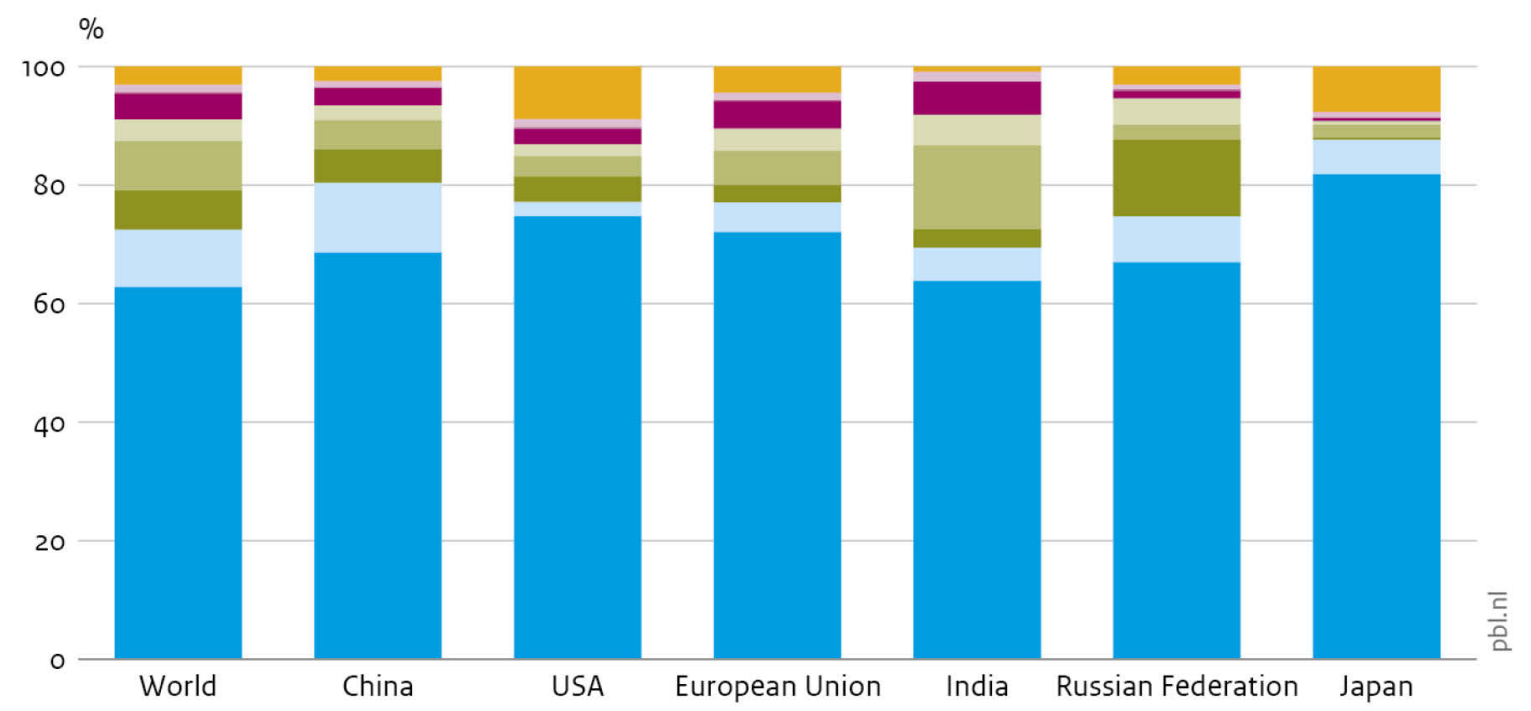

F-gases total

$\mathrm{N}_{2} \mathrm{O}$ Energy indirect and waste

$\mathrm{N}_{2} \mathrm{O}$ Industrial processes

$\mathrm{N}_{2} \mathrm{O}$ Agriculture

$$
\begin{aligned}
& \mathrm{CH}_{4} \text { Waste and other } \\
& \mathrm{CH}_{4} \text { Agriculture } \\
& \mathrm{CH}_{4} \text { Energy } \\
& \mathrm{CO}_{2} \text { Other (non-energy) } \\
& \mathrm{CO}_{2} \text { Energy }
\end{aligned}
$$

Source: EDGAR v4.3.2. (EC-JRC/PBL 2017); IEA (2017); BP (2017)

Figure 3 Greenhouse gas emissions per category in the world and for several regions/countries (Olivier et al., 2017).

Global $\mathrm{N} \mathrm{O}$ emissions per source category

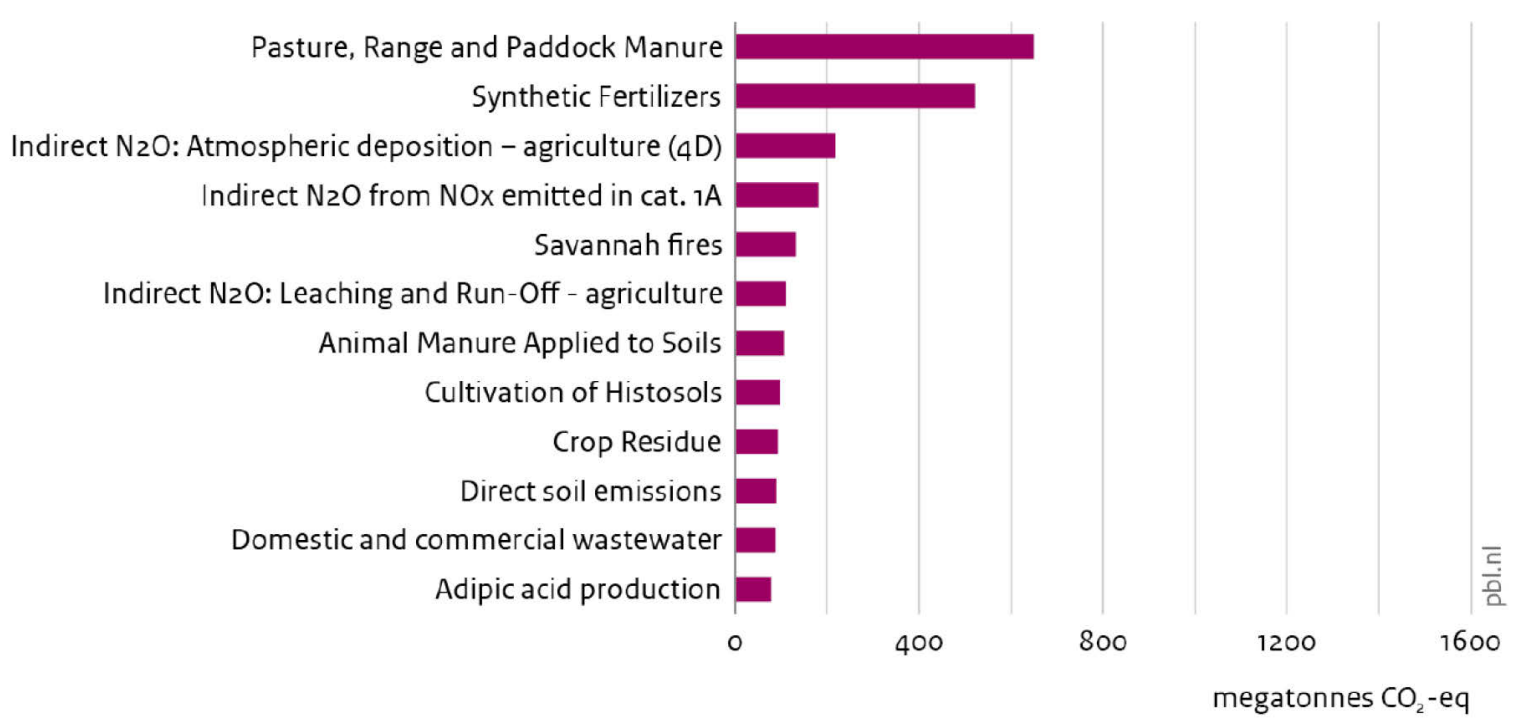

Figure 4 Top 12 sources of nitrous oxide. Nitrous oxide emission are expressed in megatonnes $\mathrm{CO}_{2}$ equivalents (Olivier et al., 2017). 


\subsubsection{The Netherlands}

In the Netherlands, $\mathrm{N}_{2} \mathrm{O}$ emission from agriculture contributes to $3.1 \%$ of the total greenhouse gas emissions (Table 1 ). The emission of $\mathrm{N}_{2} \mathrm{O}$ from Dutch agriculture amounts to $74 \%$ of the total $\mathrm{N}_{2} \mathrm{O}$ emission (Table 1 ).

The $\mathrm{N}_{2} \mathrm{O}$ emission from mineral fertilizers applied to agricultural soils amounts to $1.6 \mathrm{Mton} \mathrm{CO}_{2}$ equivalents, that is $0.8 \%$ of the total greenhouse gas emission in the Netherlands and $19.7 \%$ of the total Dutch $\mathrm{N}_{2} \mathrm{O}$ emission (Table 1 ). The direct $\mathrm{N}_{2} \mathrm{O}$ emission from organic $\mathrm{N}$ fertilizer which excludes excretion during grazing is $0.6 \%$ of the total greenhouse gas emission and $15.1 \%$ of the total $\mathrm{N}_{2} \mathrm{O}$ emission in the Netherlands.

The $\mathrm{N}_{2} \mathrm{O}$ emission in the Netherlands has strongly decreased since 1990 (Figure 5) due to a strong reduction in $\mathrm{N}_{2} \mathrm{O}$ emission from agriculture and industrial processes (i.e. nitrate fertilizer production; Figure 6). The decrease in $\mathrm{N}_{2} \mathrm{O}$ emission from agricultural soils seen since 1990 resulted from a reduction in direct $\mathrm{N}_{2} \mathrm{O}$ emission from mineral fertilizer and grazing, and reduced indirect emission from ammonia and nitrate leaching (Figure 7). These decreasing trends have mainly resulted from the manure policy in the Netherlands which led to a reduction in the amount $\mathrm{N}$ applied to soils, nitrate leaching, and ammonia emission. However, the obligatory injection of slurry in the early nineties to abate ammonia emission has resulted in an increase in $\mathrm{N}_{2} \mathrm{O}$ emission from the category organic $\mathrm{N}$ fertilizers (Figure 7). The influence of application technique on $\mathrm{N}_{2} \mathrm{O}$ emission is described in the following Chapter. The $\mathrm{N}_{2} \mathrm{O}$ emission from mineral $\mathrm{N}$ fertilizer has decreased with 0.9 Mton (more than 30\%) between 1990 and 2015 (Table 1).

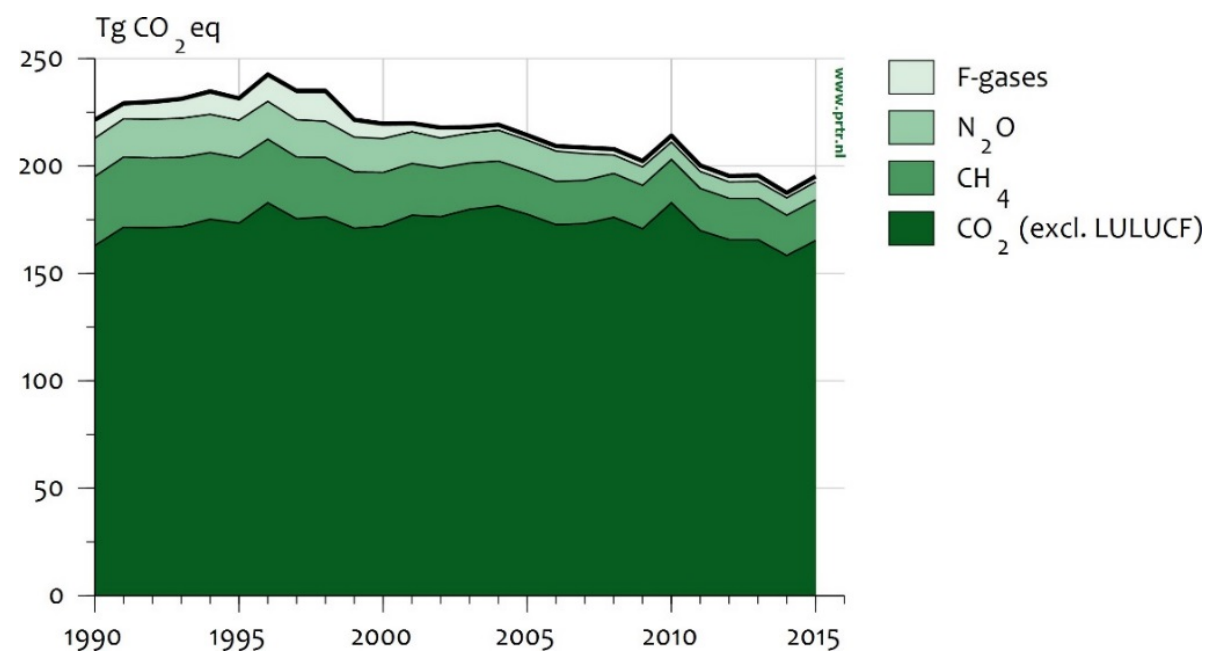

Figure 5 Greenhouse gases in the Netherlands: trend and emission levels (excl. Land Use, Land Use Change, and Forestry; LULUCF), 1990- 2015 (Coenen et al., 2017). 


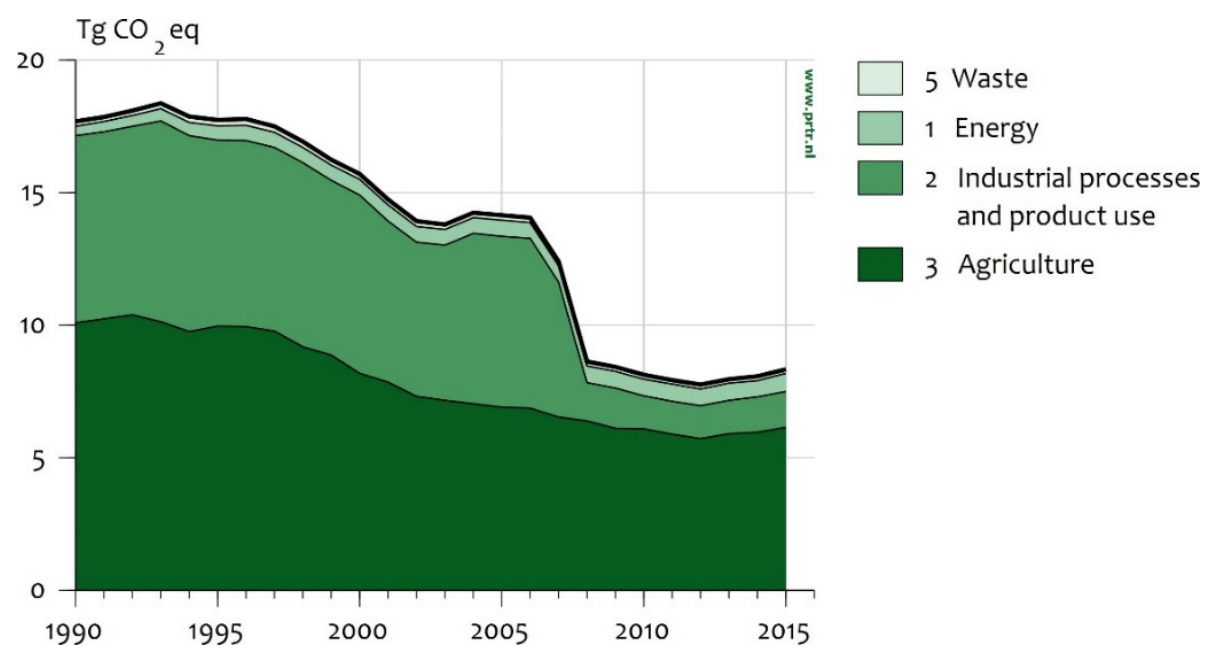

Figure $6 \quad \mathrm{~N}_{2} \mathrm{O}$ emissions in the Netherlands: trend and emission levels per sector, 1990-2015 (Coenen et al., 2017).

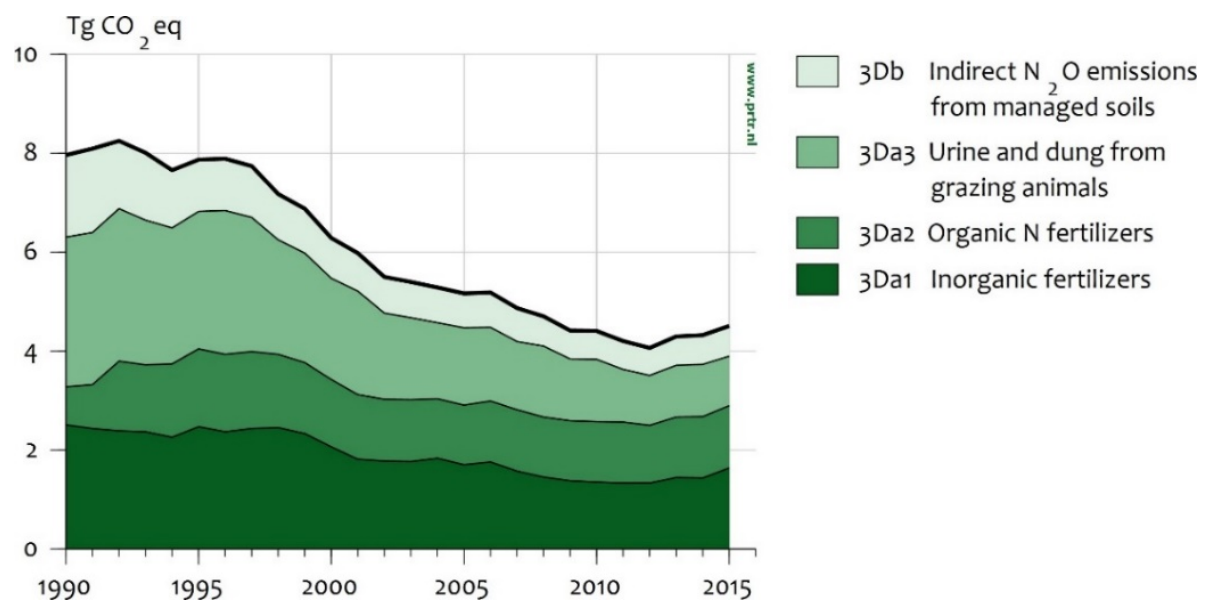

Figure 7 Category 3D Agricultural soils in the Netherlands: trend and emission levels per source category, 1990-2015 (Coenen et al., 2017). 


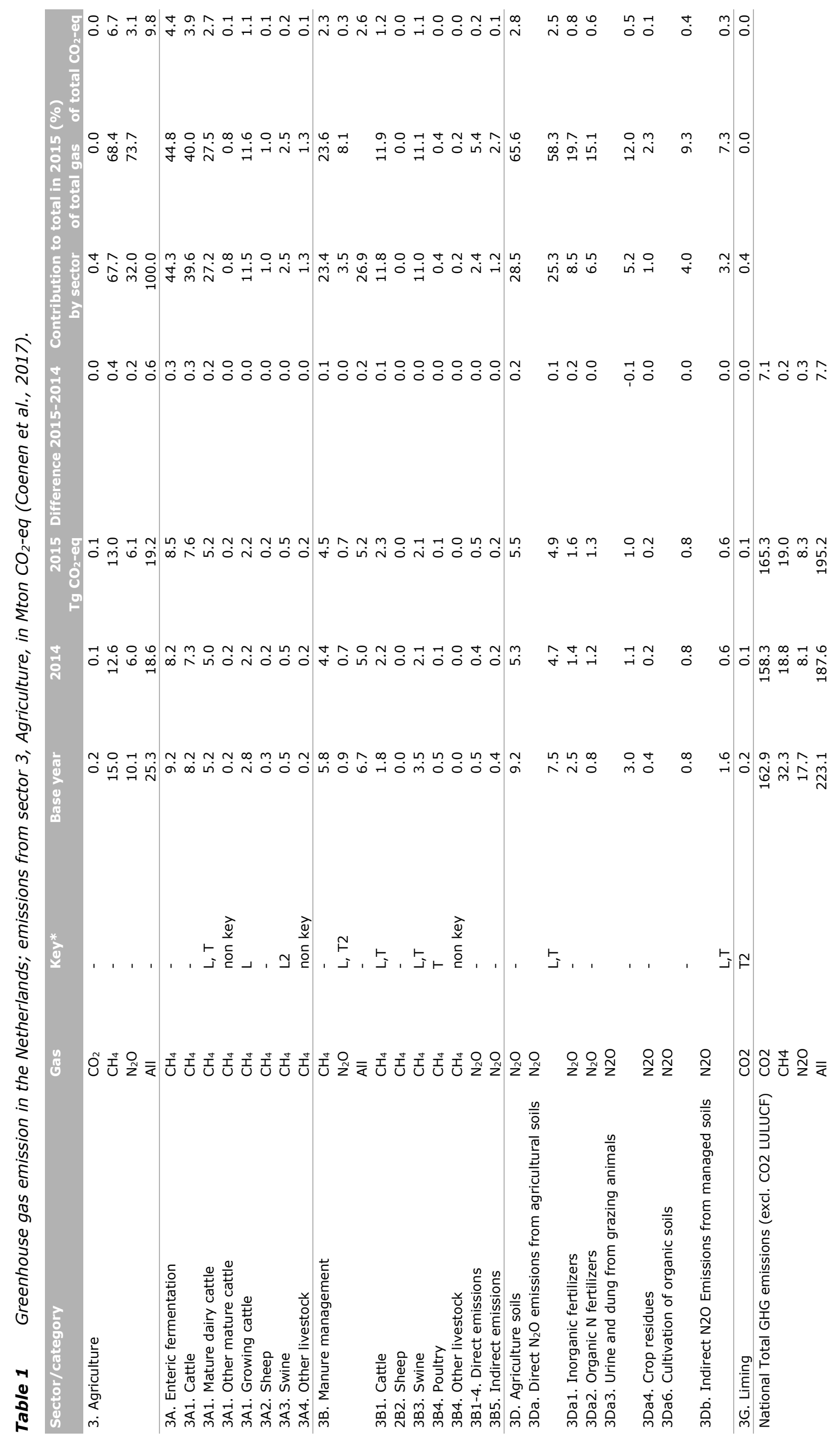




\section{$2.3 \quad$ Monitoring}

\subsubsection{Intergovernmental Panel on Climate Change (IPCC)}

The $\mathrm{N}_{2} \mathrm{O}$ emissions from agricultural soils consist of direct emissions from $\mathrm{N}$ application to soils, and indirect emissions from $\mathrm{N}$ leaching and run-off and from ammonia and nitrogen dioxide $\left(\mathrm{NH}_{3}\right.$ and $\left.\mathrm{NO}_{\mathrm{x}}\right)$ emissions. The Intergovernmental Panel on Climate Change (IPCC) has provided a general framework for the calculation of the emission of greenhouse gases (including $\mathrm{N}_{2} \mathrm{O}$ ) at the national level (2006 IPCC Guidelines for National Greenhouse Gas Inventories. https://www.ipccnggip.iges.or.jp/public/2006gl/ Volume 4 Agriculture).

The method for mineral fertilizers is described in Chapter 11: https://www.ipccnggip.iges.or.jp/public/2006gl/pdf/4_Volume4/V4_11_Ch11_N2O\&CO2.pdf

The method for manure management is described in Chapter 10: https://www.ipccnggip.iges.or.jp/public/2006gl/pdf/4_Volume4/V4_11_Ch11_N2O\&CO2.pdf

The following $\mathrm{N}$ sources are included in the methodology for estimating direct $\mathrm{N}_{2} \mathrm{O}$ emissions from managed soils (IPCC, 2006):

- Mineral (synthetic) N fertilizers;

- Organic $\mathrm{N}$ applied as fertilizer (e.g. animal manure, compost, sewage sludge, rendering waste);

- Urine and dung $\mathrm{N}$ deposited on pasture, range and paddock by grazing animals;

- $\mathrm{N}$ in crop residues (above ground and below ground), including residues from $\mathrm{N}$-fixing crops and from pasture renewal;

- $\mathrm{N}$ mineralisation associated with loss of soil organic matter resulting from changes in land-use or management of mineral soils; and

- Drainage/management of organic soils.

The $\mathrm{N}_{2} \mathrm{O}$ emission of each source is calculated according to the amount of $\mathrm{N}$ in each source (e.g. the amount of $\mathrm{N}$ applied with mineral fertilizers) and the $\mathrm{N}_{2} \mathrm{O}$ emission factor as a percentage of the $\mathrm{N}$ applied. Countries can used default emission factors (Tier 1 and Tier 2 approach) or country specific emission factors (Tier 3 approach). The Netherlands uses country specific emission factors for direct $\mathrm{N}_{2} \mathrm{O}$ emission (see next section) and IPCC defaults for indirect $\mathrm{N}_{2} \mathrm{O}$ emission.

The default IPCC $\mathrm{N}_{2} \mathrm{O}$ emission factor for mineral fertilizer and manure is $1 \%$, for grazing by cattle $2 \%$, for leaching $0.75 \%$ of the $\mathrm{N}$ leached and for ammonia volatilization $1 \%$ of the volatilized ammonia.

\subsubsection{The Netherlands}

The calculation of $\mathrm{N}_{2} \mathrm{O}$ emission from fertilizers and manures in the Netherlands is based on country specific emission factors expressed in \% of the $\mathrm{N}$ applied. Velthof and Mosquera (2011a) created a database with $\mathrm{N}_{2} \mathrm{O}$ emission factors derived from field experiments in the Netherlands. The emission factors are calculated as:

$\mathrm{N}_{2} \mathrm{O}-\mathrm{N}$ emission factor (in \%) $=\left[\left(\mathrm{N}_{2} \mathrm{O}-\mathrm{N}\right.\right.$ emission from fertilized soil) $-\left(\mathrm{N}_{2} \mathrm{O}-\mathrm{N}\right.$ emission from unfertilized soil) $] /(N$ applied $) * 100$,

where $\mathrm{N}_{2} \mathrm{O}-\mathrm{N}$ emission and $\mathrm{N}$ applied are expressed in $\mathrm{kg} \mathrm{N}$ per ha.

Emission factors were only used if they were obtained in field experiments that included replicates and an unfertilized control. This method of calculating emission factors is in agreement with the method proposed by the IPCC. For monitoring studies of more than 1 year duration, separate emission factors for each year were included in the database.

Table 2 shows the number of $\mathrm{N}_{2} \mathrm{O}$ emission factors for each $\mathrm{N}$ source and the mean, standard error, minimum and maximum emission factor. The $\mathrm{N}$ sources include mineral $\mathrm{N}$ fertilizers, livestock manures, urine excreted during grazing and crop residues. In total, there are 153 experimentally 
derived emission factors in the Netherlands resulting in an average emission factor of $1.3 \%$ of $\mathrm{N}$ applied with a standard error of $0.2 \%$. In some experiments, $\mathrm{N}_{2} \mathrm{O}$ emission was only measured for a short period lasting less than a full 6 months growing season. The average emission factor is $1.2 \pm$ $0.1 \%(n=130)$ if these shorter experiments are removed.

The average emission factor of experiments lasting longer than 6 months (Table 2) was higher for peat soils $(4.5 \pm 0.9 \%)$ than for clay soils $(1.3 \pm 0.2 \%)$ and sandy soils $(0.7 \pm 0.1 \%)$. The average emission factor was somewhat higher for grassland $(1.4 \pm 0.2 \%)$ than for arable land $(1.0 \pm 0.2 \%)$. The effect of soil type is discussed in the following Chapter.

Table $2 \quad \mathrm{~N}_{2} \mathrm{O}-\mathrm{N}$ emission factors for $\mathrm{N}$ sources derived from field experiments in the Netherlands (mean, standard error*, minimum and maximum). Emission factors are presented for the entire dataset and for a dataset with experiments that lasted at least a whole growing season (> 6 months) (Velthof and Mosquera, 2011a). ${ }^{4}$

\begin{tabular}{|c|c|c|c|c|c|c|c|c|c|c|}
\hline & \multicolumn{5}{|c|}{ Total data set } & \multicolumn{5}{|c|}{ Experiments $>6$ months } \\
\hline & \multirow[t]{2}{*}{$\mathrm{n}$} & \multicolumn{4}{|c|}{$\mathrm{N}_{2} \mathrm{O}$ emission factor, $\%$ of $\mathrm{N}$} & \multirow[t]{2}{*}{$\mathrm{n}$} & \multicolumn{4}{|c|}{$\mathrm{N}_{2} \mathrm{O}$ emission factor, $\%$ of $\mathrm{N}$} \\
\hline & & mean & st error & $\min$ & $\max$ & & mean & st error & $\min$ & $\max$ \\
\hline \multicolumn{11}{|l|}{$\mathrm{N}$ source } \\
\hline Ammonium sulphate & 6 & 0.3 & 0.1 & 0.1 & 1.0 & 3 & 0.2 & 0.1 & 0.1 & 0.3 \\
\hline Ammonium sulphate + DCD & 2 & 0.1 & 0.0 & 0.1 & 0.1 & & & & & \\
\hline Calcium Ammonium Nitrate (CAN) & 52 & 1.3 & 0.2 & -0.2 & 8.3 & 44 & 1.0 & 0.2 & -0.2 & 4.5 \\
\hline CAN + cattle slurry & 19 & 0.6 & 0.2 & 0.1 & 3.1 & 19 & 0.6 & 0.2 & 0.1 & 3.1 \\
\hline $\mathrm{CAN}+$ grazing & 8 & 3.0 & 0.8 & 0.8 & 6.8 & 8 & 3.0 & 0.8 & 0.8 & 6.8 \\
\hline Cattle slurry & 35 & 0.5 & 0.1 & -0.6 & 2.0 & 31 & 0.6 & 0.1 & -0.6 & 2.0 \\
\hline Calcium Nitrate & 3 & 5.8 & 3.4 & 0.1 & 12.0 & & & & & \\
\hline Pig slurry & 8 & 2.0 & 0.8 & 0.1 & 7.0 & 8 & 2.0 & 0.8 & 0.1 & 7.0 \\
\hline Sugar beet leaves & 2 & 0.2 & 0.1 & 0.1 & 0.3 & 2 & 0.2 & 0.1 & 0.1 & 0.3 \\
\hline Urea & 3 & 0.3 & 0.2 & 0.1 & 0.7 & & & & & \\
\hline Urine patch & 7 & 1.6 & 0.2 & 0.9 & 2.1 & 7 & 1.6 & 0.2 & 0.9 & 2.1 \\
\hline Urine/dung & 8 & 4.2 & 1.3 & 1.0 & 11.4 & 8 & 4.2 & 1.3 & 1.0 & 11.4 \\
\hline Total & 153 & 1.3 & 0.2 & -0.6 & 12.0 & 130 & 1.2 & 0.1 & -0.6 & 11.4 \\
\hline \multicolumn{11}{|l|}{ Soil } \\
\hline Clay & 39 & 1.1 & 0.2 & -0.6 & 4.6 & 35 & 1.3 & 0.2 & -0.6 & 4.6 \\
\hline Peat & 12 & 4.5 & 0.9 & 1.5 & 11.4 & 12 & 4.5 & 0.9 & 1.5 & 11.4 \\
\hline Sand & 102 & 1.0 & 0.2 & -0.2 & 12.0 & 83 & 0.7 & 0.1 & -0.2 & 7.0 \\
\hline Total & 153 & 1.3 & 0.2 & -0.6 & 12.0 & 130 & 1.2 & 0.1 & -0.6 & 11.4 \\
\hline \multicolumn{11}{|l|}{ Land use } \\
\hline Arable land & 49 & 1.0 & 0.2 & -0.6 & 7.0 & 49 & 1.0 & 0.2 & -0.6 & 7.0 \\
\hline Grassland & 104 & 1.5 & 0.2 & 0.0 & 12.0 & 81 & 1.4 & 0.2 & 0.0 & 11.4 \\
\hline Total & 153 & 1.3 & 0.2 & -0.6 & 12.0 & 130 & 1.2 & 0.1 & -0.6 & 11.4 \\
\hline $\mathrm{N}$ application rate, $\mathrm{kg} \mathrm{N}$ per ha & & 264 & 175 & 50 & 880 & & 293 & 173 & 50 & 880 \\
\hline
\end{tabular}

*a measure of uncertainty in the emission factors.

The emission factors for calcium ammonium nitrate (CAN) applied to clay soil are higher than for CAN applied to sandy soils, especially for arable land (Table 3). Emissions for livestock manure were (somewhat) smaller for clay soils than sandy soils (Table 3 ). The emission factors for CAN applied to grassland on peat soil were higher than those for CAN applied to grassland on mineral soils. The average emission factor for CAN on peat soil is $3.0 \pm 0.6 \%(n=4)$.

\footnotetext{
4 Dolfing et al. (unpublished), Schils et al. (2008), Schils et al. (2010), Van Groenigen et al. (2005), Van Groenigen et al. (2004), Velthof et al. (1996), Velthof et al. (1997), Velthof et al. (2003), Velthof et al. (2010a), and Velthof \& Mosquera (2011).
} 
Table 3 Average and standard errors of $\mathrm{N}_{2} \mathrm{O}$ emission factors for CAN and livestock manure (low ammonia emission application technique and broadcast surface application) for arable and grassland in the Netherlands (experiments > 6 months), split in factors for sand, clay, and peat soils (Velthof and Mosquera, 2011a).

\begin{tabular}{|c|c|c|c|c|c|c|c|c|c|c|c|}
\hline \multirow[t]{3}{*}{ Soil } & \multirow[t]{3}{*}{$\mathrm{N}$ source } & \multirow{3}{*}{$\begin{array}{l}\text { Manure } \\
\text { application } \\
\text { technique }\end{array}$} & \multicolumn{9}{|c|}{ Land use } \\
\hline & & & \multicolumn{3}{|c|}{ Arable land } & \multicolumn{3}{|c|}{ Grassland } & \multicolumn{3}{|l|}{ All } \\
\hline & & & Average & se & $\mathrm{n}$ & Average & se & $\mathrm{n}$ & Average & se & $\mathrm{n}$ \\
\hline \multirow[t]{4}{*}{ Clay } & CAN & & $1.7 \pm$ & 0.6 & 5 & $1.1 \pm$ & 0.3 & 9 & $1.3 \pm$ & 0.3 & 14 \\
\hline & Livestock manure & Low emission & $1.1 \pm$ & 0.3 & 7 & $0.3 \pm$ & 0.1 & 2 & $0.9 \pm$ & 0.3 & 9 \\
\hline & & Surface & & & & 0.1 & 0.1 & 2 & 0.1 & 0.1 & 2 \\
\hline & Average & & $1.3 \pm$ & 0.3 & 12 & 0.8 & 0.2 & 13 & 1.1 & 0.2 & 25 \\
\hline \multirow[t]{4}{*}{ Sand } & CAN & & $0.2 \pm$ & 0.1 & & $0.7 \pm$ & 0.2 & 17 & $0.5 \pm$ & 0.1 & 26 \\
\hline & Livestock manure & Low emission & $1.5 \pm$ & 0.5 & 14 & $0.3 \pm$ & 0.1 & 5 & $1.2 \pm$ & 0.4 & 19 \\
\hline & & Surface & $0.6 \pm$ & 0.2 & 6 & 0.1 & 0.0 & 3 & 0.5 & 0.2 & 9 \\
\hline & Average & & $0.9 \pm$ & 0.2 & 29 & 0.5 & 0.1 & 25 & $0.7 \pm$ & 0.1 & 54 \\
\hline \multicolumn{2}{|c|}{ Average mineral soils } & & $1.0 \pm$ & 0.2 & 41 & $0.6 \pm$ & 0.1 & 38 & $0.8 \pm$ & 0.1 & 79 \\
\hline Peat & CAN & & & & & $3.0 \pm$ & 0.6 & 4 & 3.0 & 0.6 & 4 \\
\hline
\end{tabular}

On the basis of the analysis of the dataset of emission factors in the Netherlands, it was recommended that specific emission factors are used for manures applied to grassland and arable land on mineral soils (Table 4). The average emission factors in Table 4 were used to calculate $\mathrm{N}_{2} \mathrm{O}$ emissions in the Netherlands (Vonk et al., 2018). The emission factor that is used in the Netherlands for CAN and other fertilizer types in mineral soils is somewhat smaller than the IPCC default factor of $1 \%$. The $3 \%$ emission factor for peat soil is higher than the IPCC default of $1 \%$.

The emission factor for CAN is used for all fertilizer types. In the previous monitoring protocol (before 2013), an emission factor of $0.97 \%$ for mineral soils and $1.94 \%$ for peat soil was used for nitrate containing fertilizers, and $\mathbf{0 . 4 8 \%}$ for mineral soils and $0.97 \%$ for peat soils for ammonium fertilizers. However, the number of measurements for ammonium fertilizers is small meaning that no fertilizer type specific emission factors are currently used.

Table 4 Average $\mathrm{N}_{2} \mathrm{O}$ emission factors (in \% of $\mathrm{N}$ applied) and standard errors for CAN and livestock manure in the Netherlands based on the dataset with emission factors obtained from experiments in the Netherlands. The emission factors for manure applied to peat soil were calculated from results from an incubation study (Velthof and Mosquera, 2011a).

\begin{tabular}{|c|c|c|c|c|c|}
\hline \multirow[t]{2}{*}{ Soil type } & \multirow[t]{2}{*}{ Source } & \multirow{2}{*}{$\begin{array}{l}\text { Application } \\
\text { technique }\end{array}$} & \multicolumn{3}{|l|}{ Land-use } \\
\hline & & & Arable land & Grassland & All \\
\hline \multirow[t]{3}{*}{ Mineral soils } & CAN & & $\begin{array}{c}0.7 \pm 0.3 \\
(n=14)\end{array}$ & $\begin{array}{c}0.8 \pm 0.1 \\
(n=26)\end{array}$ & $\begin{array}{c}0.8 \pm 0.1 \\
(n=40)\end{array}$ \\
\hline & Livestock manure & Low emission & $\begin{array}{c}1.3 \pm 0.3 \\
(n=21)\end{array}$ & $\begin{array}{c}0.3 \pm 0.1 \\
(n=7)\end{array}$ & $\begin{array}{c}1.1 \pm 0.2 \\
(n=28)\end{array}$ \\
\hline & & Surface & $\begin{array}{c}0.6 \pm 0.2 \\
(n=6)\end{array}$ & $\begin{array}{c}0.1 \pm 0.02 \\
(n=5)\end{array}$ & $\begin{array}{c}0.4 \pm 0.2 \\
(n=11)\end{array}$ \\
\hline \multirow[t]{3}{*}{ Peat soil } & CAN & & & $\begin{array}{c}3.0 \pm 0.6 \\
(n=4)\end{array}$ & \\
\hline & Livestock manure & Low emission & & $1^{*}$ & \\
\hline & & Surface & & $0.5^{*}$ & \\
\hline
\end{tabular}




\section{Processes and controlling factors}

\section{$3.1 \quad$ Processes}

The biological processes nitrification, denitrification, and nitrifier denitrification, and the chemical process chemical denitrification are the main mechanisms through which $\mathrm{N}_{2} \mathrm{O}$ is produced. These processes are discussed in this chapter.

\subsubsection{Nitrification}

Nitrification is the oxidation of ammonium $\left(\mathrm{NH}_{4}{ }^{+}\right)$to nitrite $\left(\mathrm{NO}_{2}^{-}\right)$and nitrate $\left(\mathrm{NO}_{3}{ }^{-}\right)$; Figure 8 . Bacterial species that are involved in the first step (transformation of $\mathrm{NH}_{4}^{+}$to $\mathrm{NO}_{2}^{-}$) generally belong to Nitrosomonas and those involved in the second step (transformation of $\mathrm{NO}_{2}^{-}$to $\mathrm{NO}_{3}^{-}$) to Nitrobacter.

Nitrification occurs under aerobic (oxygen rich) conditions. The majority of bacteria involved are autotrophs and use $\mathrm{CO}_{2}$ as a source of carbon. Hydroxylamine $\left(\mathrm{NH}_{2} \mathrm{OH}\right)$ is an intermediate product of nitrification. Nitrous oxide is a by-product of nitrification that is produced at low $\mathrm{O}_{2}$ concentrations. Some nitrifiers use organic carbon (C) as an energy source in a process called heterotrophic nitrification.

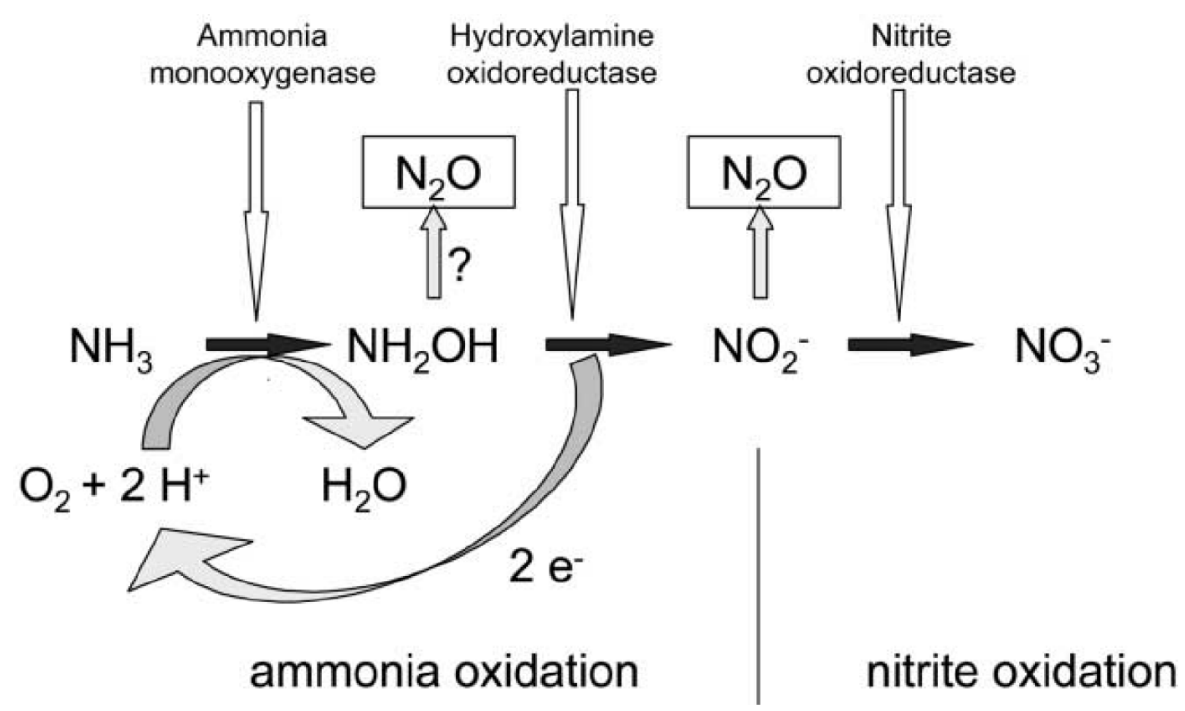

Figure 8 Pathway of nitrification (Wrage et al., 2001).

\subsubsection{Denitrification}

\subsubsection{Biological denitrification}

Using available carbon sources as a source of energy, denitrifying bacteria produce $\mathrm{N}_{2} \mathrm{O}$ under anaerobic conditions during the stepwise reduction of $\mathrm{NO}_{3}{ }^{-}$to dinitrogen $\left(\mathrm{N}_{2}\right)$ (Firestone et al., 1989). Several intermediates are developed during denitrification (Figure 9): $\mathrm{NO}_{2}^{-}$, nitric oxide ( $\mathrm{NO}$ ), $\mathrm{N}_{2} \mathrm{O}$ and $\mathrm{N}_{2}$. All these products may be released during denitrification. Reactions are regulated by the enzymes nitrate reductase and nitrite reductase (Figure 9; Coyotzi et al., 2017). The reactions are carried out by denitrifying bacteria that are widely distributed across the bacterial taxa. Examples of these include Pseudomonas, Bacillus, Thiobacillus, Propionibacterium (Firestone, 1982). These predominantly heterotrophic microorganisms are facultative anaerobes that are able to use $\mathrm{NO}_{3}{ }^{-}$instead of oxygen as an electron acceptor in respiration to cope with low oxygen or anaerobic conditions (Wrage et al., 
2001). Bacteria are mostly responsible for emission of $\mathrm{N}_{2} \mathrm{O}$ in soils (Syakila \& Kroeze, 2011; Reay et al., 2012), however, fungi are also able to denitrify (Matsuoka et al., 2017). Nitrous oxide is a regular intermediate in denitrification which contrasts with nitrification where $\mathrm{N}_{2} \mathrm{O}$ is a by-product.

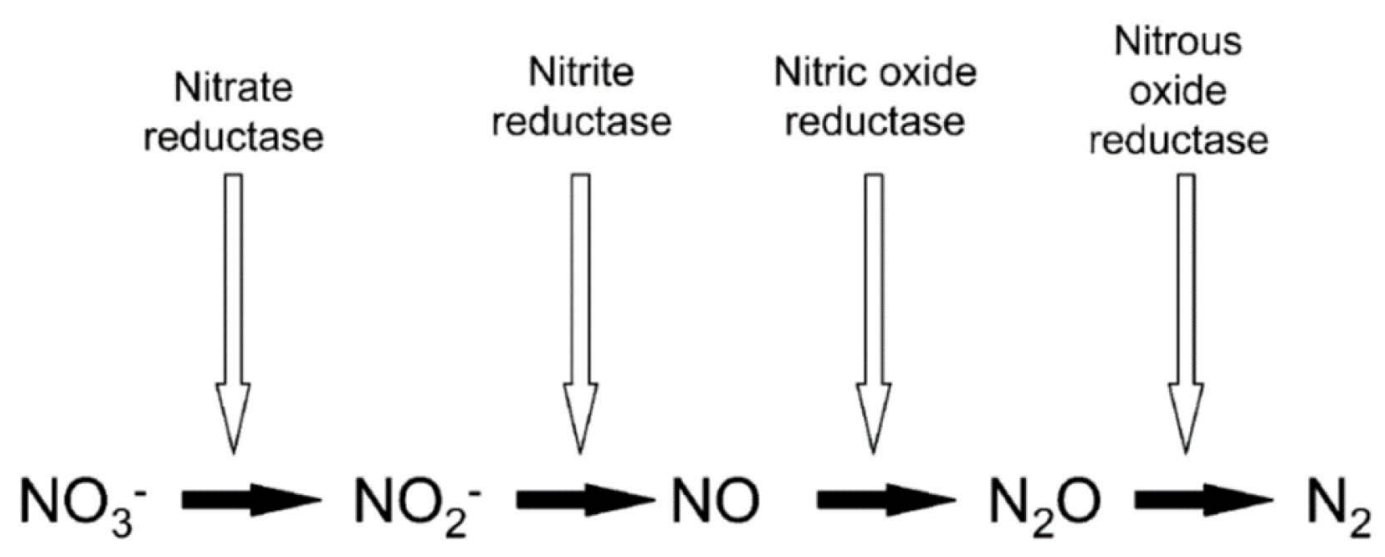

Figure 9 Pathway of denitrification (Wrage et al., 2001).

\subsubsection{Chemical denitrification}

Chemical denitrification is the process by which $\mathrm{NO}_{2}$ and $\mathrm{NH}_{2} \mathrm{OH}$ are chemically reduced to $\mathrm{N}_{2} \mathrm{O}$ (Figure 10; (Chalk and Smith, 1983; Heil et al., 2016). Several reactions are involved, i.e., selfdecomposition of $\mathrm{NO}_{2}{ }^{-}$, reactions of $\mathrm{NO}_{2}{ }^{-}$with reduced metal cations, nitrosation of soil organic matter by $\mathrm{NO}_{2}^{-}$, a reaction between $\mathrm{NO}_{2}^{-}$and $\mathrm{NH}_{2} \mathrm{OH}$, and the oxidation of $\mathrm{NH}_{2} \mathrm{OH}$ by iron $\left(\mathrm{Fe}^{3+}\right.$ ) or manganese $\left(\mathrm{MnO}_{2}\right)$.

In most soils, the oxidation of $\mathrm{NO}_{2}{ }^{-}$to $\mathrm{NO}_{3}{ }^{-}$proceeds faster than the conversion of $\mathrm{NH}_{3}$ to $\mathrm{NO}_{2}{ }^{-}$ meaning that $\mathrm{NO}_{2}-$ does not accumulate. Under alkaline conditions (high $\mathrm{pH}$ ), $\mathrm{NH}_{3}$ is formed from $\mathrm{NH}_{4}{ }^{+}$. $\mathrm{NH}_{3}$ is toxic for the bacteria that transform $\mathrm{NO}_{2}^{-}$into $\mathrm{NO}_{3}^{-}$resulting in accumulation of $\mathrm{NO}_{2}$. This process may increase $\mathrm{N}_{2} \mathrm{O}$ emission through chemical denitrification. Emission of $\mathrm{N}_{2} \mathrm{O}$ from accumulated $\mathrm{NO}_{2}^{-}$may occur after application of urea fertilizer to all soil types and ammonium fertilizer to calcareous soils, and in urine patches on grazed grassland.

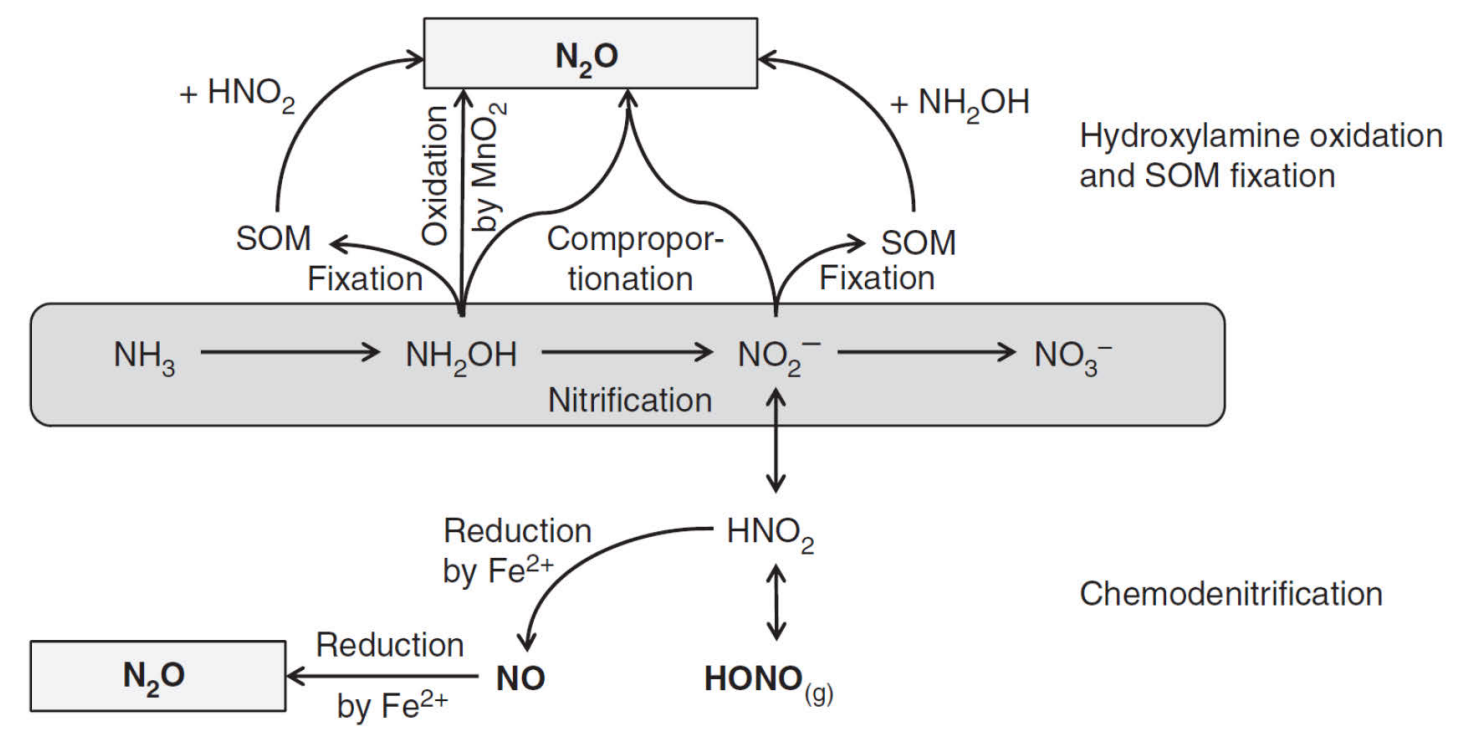

Figure 10 Pathways of chemical denitrification (Heil et al., 2016). 


\subsubsection{Nitrifier denitrification}

Nitrifier denitrification is the pathway of nitrification in which $\mathrm{NH}_{4}$ is oxidized by autotrophic nitrifiers to $\mathrm{NO}_{2}{ }^{-}$followed by the reduction of $\mathrm{NO}_{2}^{-}$to $\mathrm{NO}, \mathrm{N}_{2} \mathrm{O}$ and $\mathrm{N}_{2}$ (Figure $11 ;$ Wrage et al., 2001; 2018). Due to experimental difficulties and a lack of awareness of nitrifier denitrification, not much is known about this mechanism of $\mathrm{N}_{2} \mathrm{O}$ production. Experiments indicate that nitrifier denitrification occurs at relatively high ammonium concentrations, low $\mathrm{O}_{2}$ and low $\mathrm{C}$ contents.

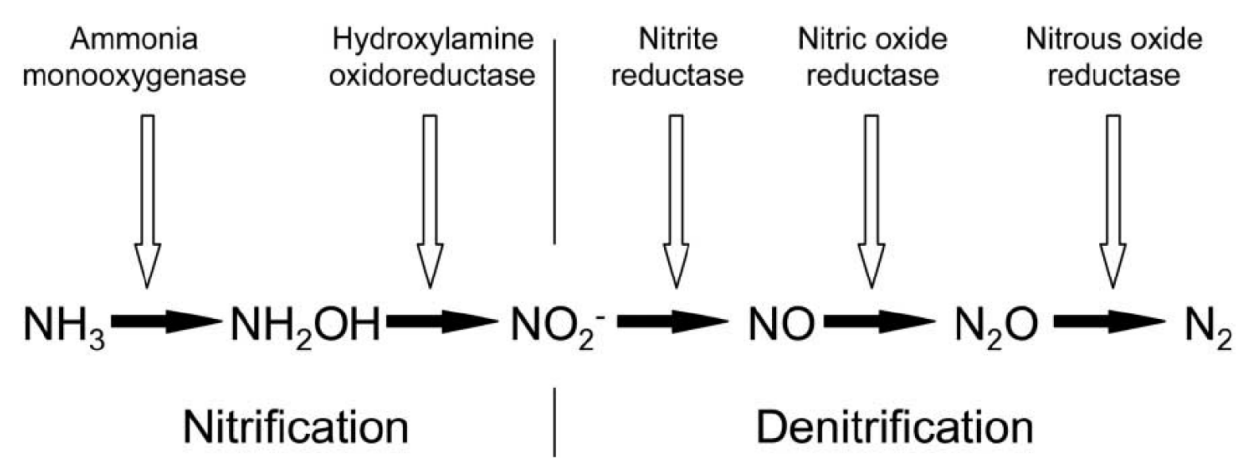

Figure 11 Pathway of nitrifier denitrification (Wrage et al., 2001).

\subsection{Controlling factors}

Soil type and conditions, weather conditions, and $\mathrm{N}$ management have a large effect on $\mathrm{N}_{2} \mathrm{O}$ production in soils (Butterbach-Bahl et al., 2013; Lesschen et al., 2011). Rapid changes in soil contents of mineral $\mathrm{N}$ (e.g. by application of $\mathrm{N}$ fertilizers and manure), available carbon (e.g. by application of crop residues and manure), oxygen (e.g. rainfall, groundwater fluctuations, and biological oxygen consumption in the soil) and temperature can result in strong fluctuations in $\mathrm{N}_{2} \mathrm{O}$ emission (Figure 12). Highest production is found in fertilized soils during relatively wet soil conditions and especially in soils rich in organic matter (e.g. grassland soils, peat soils or soils to which organic matter containing products are applied).

In general, the total $\mathrm{N}$ losses by denitrification $\left(\mathrm{N}_{2}+\mathrm{N}_{2} \mathrm{O}+\mathrm{NO}\right)$ increase with increasing temperature, available $\mathrm{C}$ content, $\mathrm{pH}$ and nitrate contents and decreasing oxygen content (Table 5). However, for $\mathrm{N}_{2} \mathrm{O}$ emission, it is also important to consider the proportion of $\mathrm{N}_{2} \mathrm{O}$ to total $\mathrm{N}$ denitrification loss. The $\mathrm{N}_{2} \mathrm{O} / \mathrm{N}_{2}$ ratio of denitrification products increases when nitrate concentration, oxygen concentration or available carbon increases and temperature or $\mathrm{pH}$ decreases (Table 5). This demonstrates the complexity of predicting $\mathrm{N}_{2} \mathrm{O}$ emission. It should be noted that even at suboptimal conditions for denitrification (low oxygen, low $\mathrm{pH}$ and low temperature), relatively high $\mathrm{N}_{2} \mathrm{O}$ emission may occur.

The nitrification rate increases with increasing ammonium content, oxygen content, or temperature and decreasing $\mathrm{pH}$. The highest $\mathrm{N}_{2} \mathrm{O}$ production is generally found during suboptimal conditions for nitrification, e.g., during wet conditions. These are also conditions in which $\mathrm{N}_{2} \mathrm{O}$ production during denitrification is highest. Therefore, it is difficult to determine whether the mechanism of $\mathrm{N}_{2} \mathrm{O}$ production is nitrification or denitrification in wet soils containing both ammonium and nitrate.

A more in depth description of the factors controlling $\mathrm{N}_{2} \mathrm{O}$ emission is given in the following sections. 
Table 5 Effects of factors on denitrification rate and $\mathrm{N}_{2} \mathrm{O} / \mathrm{N}_{2}$ ratio on the end products of denitrification (Based on Delwiche, 1981; Firestone, 1982; Firestone et al., 1989; Knowles, 1982).

\begin{tabular}{lcc} 
& denitrification & + \\
Increasing nitrate content & + & - \\
\hline Increasing oxygen content & + & + \\
\hline Increasing available organic carbon & + & - \\
\hline Increasing temperature & - & + \\
\hline Decreasing $\mathrm{pH}$ & + & + \\
\hline
\end{tabular}

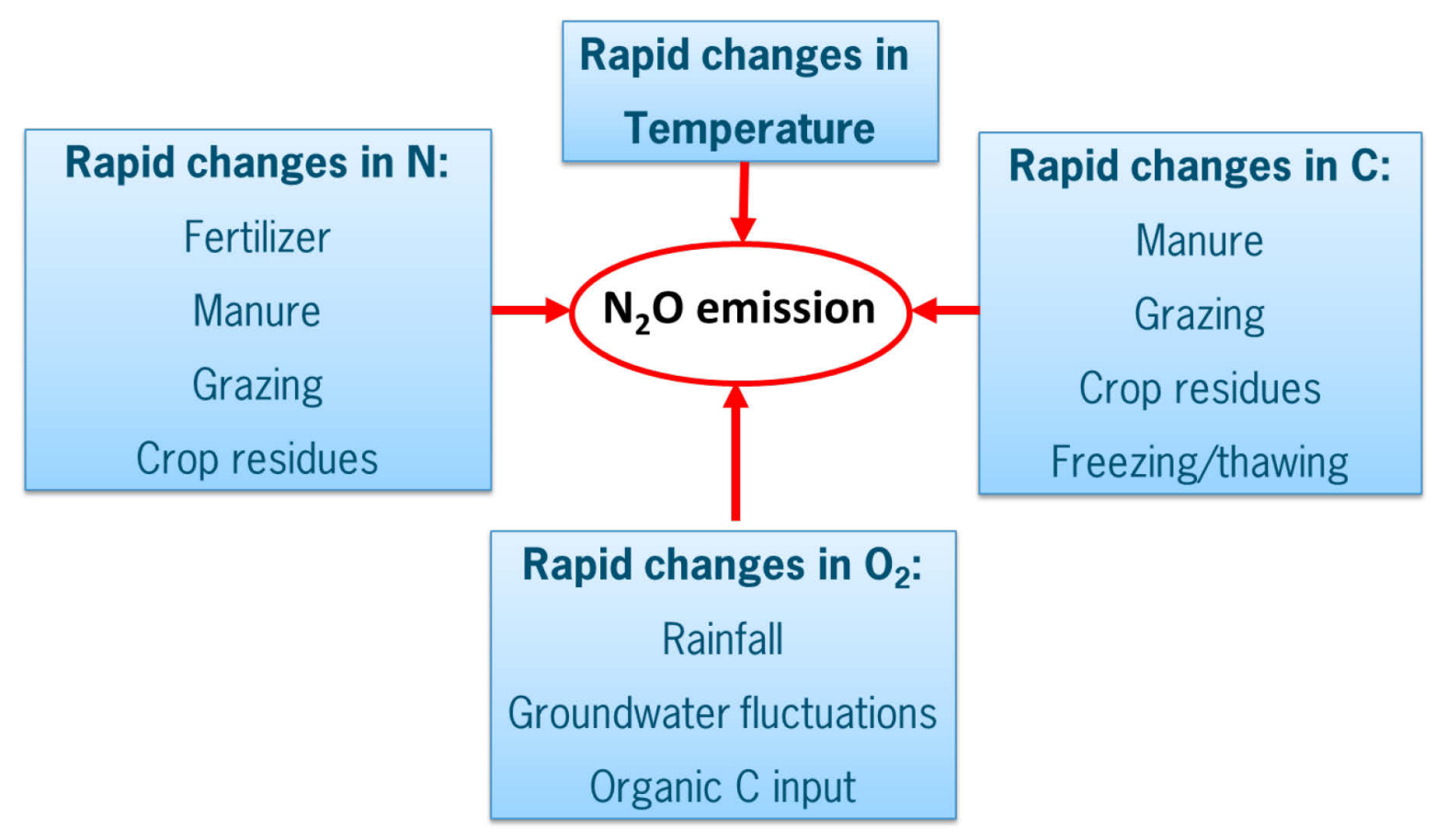

Figure 12 Factors controlling $\mathrm{N}_{2} \mathrm{O}$ emission from soils.

\subsubsection{Nitrogen type and concentration}

Mineral or organic $\mathrm{N}$ fertilizer type affects $\mathrm{N}_{2} \mathrm{O}$ in several ways, i.e.

- via the type of applied $\mathrm{N}$ (urea, $\mathrm{NO}_{3}{ }^{-}, \mathrm{NH}_{4}{ }^{+}$, and/or organic $\mathrm{N}$ ) and the effects on nitrification and denitrification;

- via the presence of available carbon (stimulates denitrification and oxygen consumption in the soil);

- via the addition of other compounds (nutrients, metals, lime, water) affecting biological, chemical and physical soil processes, including $\mathrm{pH}$ and salt concentration (EC), and

- via the application technique (soil compaction, placement/concentration of $\mathrm{N}$ and $\mathrm{C}$ in the soil).

Emissions of $\mathrm{N}_{2} \mathrm{O}$ from $\mathrm{N}$ fertilizer types are shown in the following Chapter. The rate of denitrification increases with increasing nitrate content. The portion of $\mathrm{N}_{2} \mathrm{O}$ that is released during denitrification (relative to $\mathrm{N}_{2}$ ) increases with increasing nitrate concentration (Table 5).

Emission factors used in the monitoring of $\mathrm{N}_{2} \mathrm{O}$ emission (\% $\mathrm{N}$ applied) assume that there is a linear relationship between $\mathrm{N}$ application rate and $\mathrm{N}_{2} \mathrm{O}$ emission. However, as demonstrated in the examples in Figures 13 and 14, this is not always the case. In these experiments, the emission factors increased with increasing $\mathrm{N}$ application rate. This non-linear response of $\mathrm{N}_{2} \mathrm{O}$ emission to $\mathrm{N}$ application rate is not accounted for in the IPCC guidelines or the protocol for the Netherlands. 


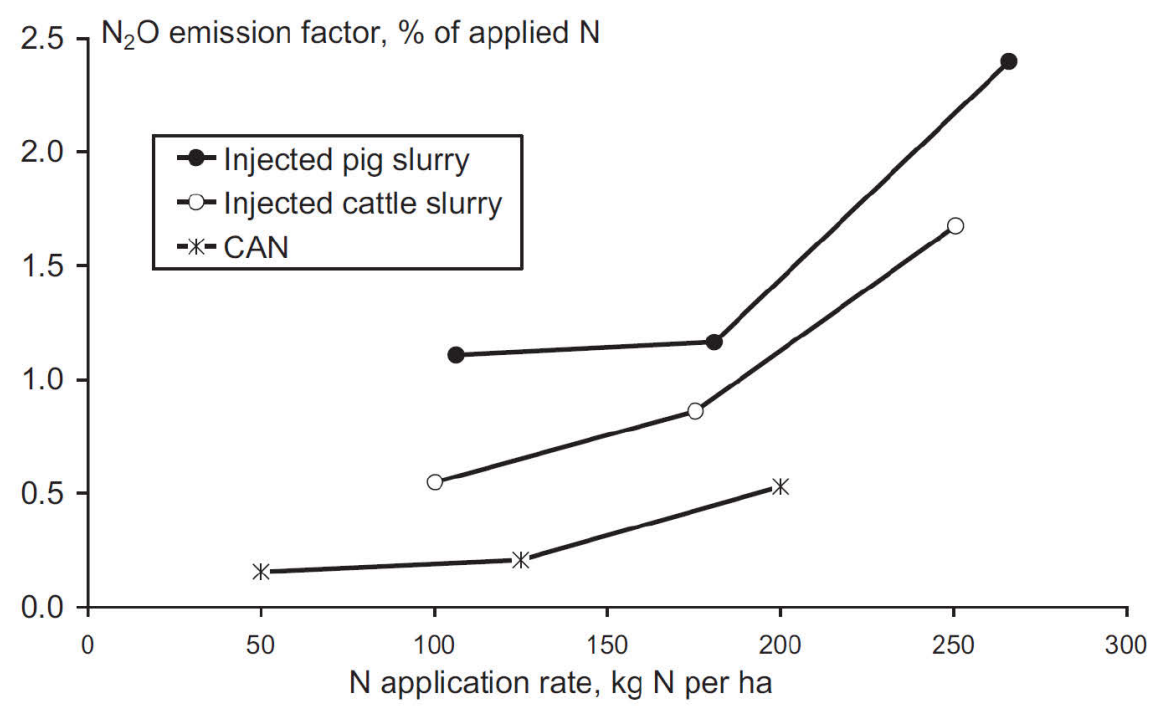

Figure 13 Relation between the $N$ application rate of injected pig and cattle slurries and calcium ammonium nitrate (CAN) application and the $\mathrm{N}_{2} \mathrm{O}$ emission factor for maize on a sandy soil (Velthof and Mosquera, 2011b).

Total $\mathrm{N}_{2} \mathrm{O}$ emission, $\mathrm{kg} \mathrm{N} \mathrm{ha}^{-1}$

A

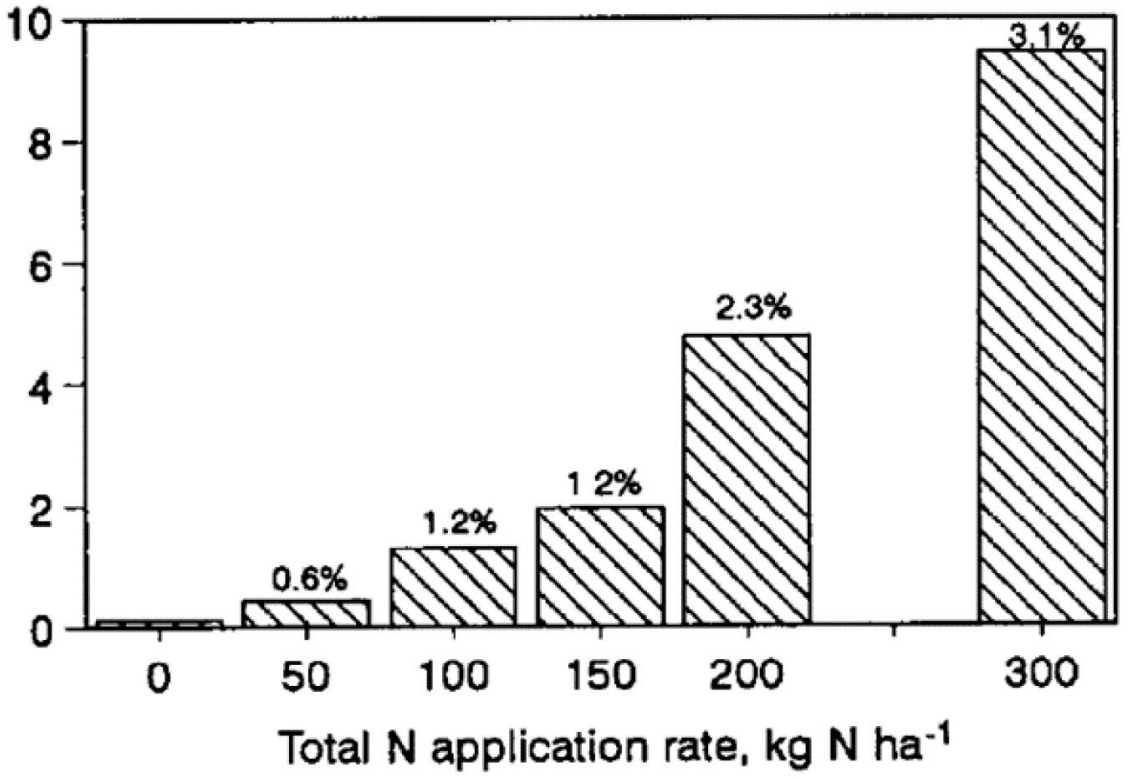

Figure 14 Relation between the $N$ application rate of calcium ammonium nitrate and the $\mathrm{N}_{2} \mathrm{O}$ emission factor for grassland on a sandy soil (Velthof et al., 1996). The percentages near the bars indicate the emission factor.

\subsubsection{Carbon/organic matter}

Easily degradable organic matter is an energy source for denitrification. Therefore, the presence of organic matter in soil and the application of organic matter via manure or crop residues affects denitrification and $\mathrm{N}_{2} \mathrm{O}$ emission.

Potential denitrification rates (i.e. denitrification measured in soil with an excess of nitrate during incubation under anaerobic conditions at $20^{\circ} \mathrm{C}$ ) are highest in soils and soil layers with the highest organic matter content, i.e., higher in peat soils than in mineral soils, higher on grassland than on arable land (Velthof, 2003), and higher in top soil layers than in deep soil layers (Table 6). 
Table 6 Potential denitrification rates in Dutch soils (Assinck et al., 2005).

\begin{tabular}{l|cccc|cc}
\hline \multicolumn{5}{c|}{} & \multicolumn{5}{c|}{ Grerage potential denitrification, $\mathrm{mg} \mathrm{N} \mathrm{kg}^{-1} \mathrm{~d}^{-1}$} \\
\cline { 1 - 3 } & Peat & Clay & Loam & Sand & \multicolumn{2}{c}{ Maize land } \\
\cline { 1 - 3 } Layer, cm & Loam & Sand \\
\hline $0-20$ & 267 & 151 & 65 & 26 & 20 & 11 \\
\hline $20-40$ & 317 & 125 & 30 & 4 & 9 & 4 \\
\hline $40-60$ & 116 & 5 & 1 & 0.1 & 1 & 0.1 \\
\hline $60-80$ & 61 & 0.9 & 0.3 & 0.5 & 0.3 & 0 \\
\hline $80-100$ & 39 & 0.6 & 0.2 & 0.2 & 0.1 & 0 \\
\hline
\end{tabular}

\subsubsection{Moisture content and aeration}

Figure 15 schematically shows that during nitrification and denitrification the highest $\mathrm{N}_{2} \mathrm{O}$ production occurs under intermediate soil moisture conditions (about $60 \%$ water-filled pore space).

The $\mathrm{N}_{2} \mathrm{O}$ emission is low during dry and extremely wet conditions (saturated soil).

Rainfall or irrigation can increase $\mathrm{N}_{2} \mathrm{O}$ emission for a short period (several hours), as shown in Figure 16. This risk is highest just after $\mathrm{N}$ fertilizer application. The higher the mineral $\mathrm{N}$ content in the soil, the larger the risk that rainfall will increase $\mathrm{N}_{2} \mathrm{O}$ emission.

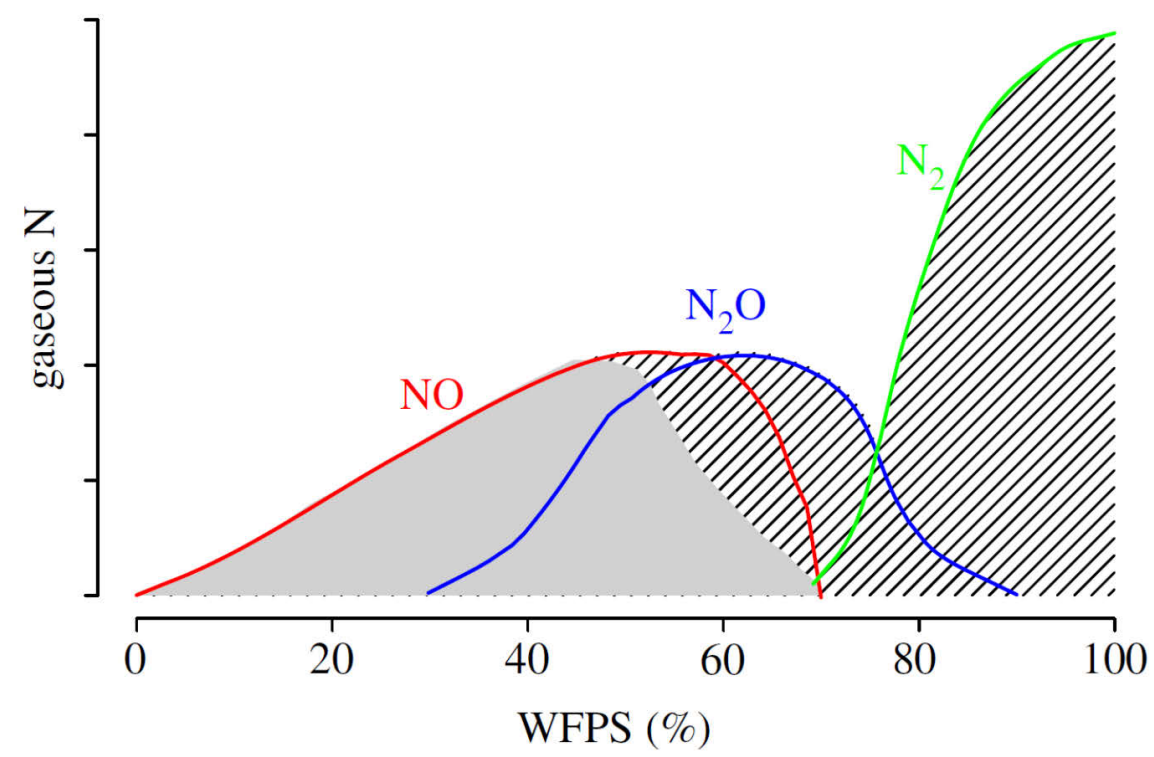

Figure 15 Proposed relative contributions of nitrification (solid grey shading) and denitrification (hatched shading) to gaseous $N$ emissions as a function of water-filled pore space (WFPS). (Pilegaard, 2013). 


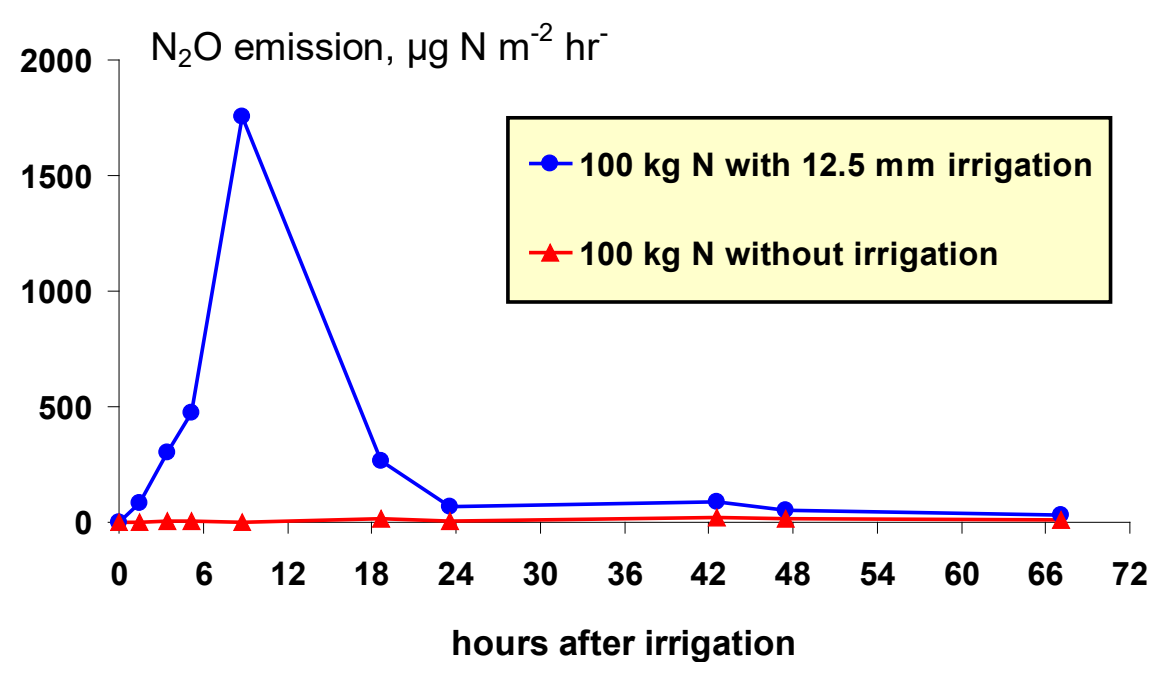

Figure 16 Emission of $\mathrm{N}_{2} \mathrm{O}$ from grassland after application of $100 \mathrm{~kg} \mathrm{~N}$ per ha as calcium ammonium nitrate with and without $12.5 \mathrm{~mm}$ irrigation water (Van der Bolt, unpublished results).

\subsubsection{Temperature}

Denitrification rate increases with increasing temperature. The portion of intermediate $\mathrm{N}_{2} \mathrm{O}$ relative to $\mathrm{N}_{2}$ that is released during denitrification decreases with increasing temperature (Table 5). Significant $\mathrm{N}_{2} \mathrm{O}$ emissions may occur at low temperature.

During cycles of freezing and thawing a significant amount of $\mathrm{N}_{2} \mathrm{O}$ may be released (Kaiser et al., 1998). The mechanism governing this is not yet clear, but it may be related to an increase in accessibility of organic matter (Christensen and Christensen, 1991).

\subsection{5 $\mathrm{pH}$}

The rate of chemical reduction of $\mathrm{N}_{2} \mathrm{O}$ to $\mathrm{N}_{2}$ in soil is slower at low soil pH (Granli \& Bøckman, 1994; Liu et al., 2014). Therefore, liming can decrease $\mathrm{N}_{2} \mathrm{O}$ emissions (Shaaban et al., 2018). According to Eurofins Agro (soil laboratory in the Netherlands), approximately one in three maize fields feature a $\mathrm{pH}$ value below 5, which may be considered low if the guideline of $\mathrm{pH} 5.5$ for sandy soils is observed. ${ }^{5}$ Liming may improve yield and $\mathrm{N}$ uptake, as well as reducing $\mathrm{N}_{2} \mathrm{O}$ emission.

\subsubsection{Soil type and structure}

Soil type and structure influence $\mathrm{N}_{2} \mathrm{O}$ emission via different mechanisms involving $\mathrm{O}_{2}$ concentration, available carbon, water and gas transport, and $\mathrm{pH}$. These factors influence the rates of mineralisation, nitrification and denitrification, and the $\mathrm{N}_{2} \mathrm{O} / \mathrm{N}_{2}$ ratio of the end products of nitrification and denitrification. Soil cultivation affects the aeration of the soil which in turn affects the rates of these $\mathrm{N}$ transformation processes and emission of $\mathrm{N}_{2} \mathrm{O}$. The effect of soil cultivation on $\mathrm{N}_{2} \mathrm{O}$ emission (decrease or increase) will depend on the local conditions and are difficult to predict.

The $\mathrm{N}_{2} \mathrm{O}$ emission from peat soils is much higher than that of mineral soils because the organic matter contents and groundwater levels (wet conditions) are much higher in peat soils than in sandy soils.

\subsubsection{Interactions between factors}

There are also many interactions between the factors that control $\mathrm{N}_{2} \mathrm{O}$ emission. These interactions make the overall effect on $\mathrm{N}_{2} \mathrm{O}$ emission difficult to predict. Models are mostly based on emission factors that are a highly simplified presentation of reality. Some process-based models predict $\mathrm{N}_{2} \mathrm{O}$ emission, but the accuracy is uncertain if the environmental conditions for which the model is applied differs from the conditions for which the model has been parametrized. The model DNDC (DeNitrification DeComposition) is the most widely used model for $\mathrm{N}_{2} \mathrm{O}$ (e.g. Gilhespy et al., 2014).

\footnotetext{
5 http://eurofins-agro.com/nl-nl/expertise/bemesting/artikelen/bekalken-het-voorjaar-zinvol-niet
} 


\section{$4 \quad$ Agricultural value of nitrogen fertilizers and manures}

\subsection{Nitrogen use efficiency of mineral fertilizer types}

The results of several decades of research on efficiency of mineral $\mathrm{N}$ fertilizers in the Netherlands were summarized in a review paper by Van Burg et al. (1982).

The main conclusions with regard to the use efficiency of mineral $\mathrm{N}$ fertilizers applied to arable land were:

- The average $\mathrm{N}$ efficiency of urea in experiments was $0.90-0.95$ compared to CAN. The $\mathrm{N}$ efficiency of urea was lowest on calcareous clay soils, most probably because of ammonia emission.

- The average $\mathrm{N}$ efficiency of urean (a solution of urea and ammonium nitrate) was similar to that of CAN.

- The variation in $\mathrm{N}$ efficiency of urea and urean was large. This was attributed to large variations in ammonia emissions from these fertilizers (high ammonia emission during dry weather conditions and low ammonia emission during wet weather conditions).

The main conclusions of Van Burg et al. (1982) with regard to the use efficiency of mineral $\mathrm{N}$ fertilizers applied to grassland were:

- The average $\mathrm{N}$ efficiency of ammonium sulphate compared to CAN was 0.90 on clay, 0.85 on peat, and 0.91 on sand.

- The differences in $\mathrm{N}$ efficiency between ammonium sulphate and CAN are dependent on weather conditions. Nitrate leaching from CAN reduces its efficiency under wet conditions whereas ammonium sulphate may cause burning of leaves during dry conditions.

- Repeated application of ammonium sulphate acidifies the soils which negatively affects the mineral composition of grass (lower magnesium and calcium contents) and the botanical composition of the sward (see Section 4.3).

- The average $\mathrm{N}$ efficiency of urea was much lower than that of CAN $(0.75-0.85)$ and was attributed to ammonia emission from urea.

- The relative $\mathrm{N}$ efficiency of urea was higher than that of CAN during very wet conditions which was probably due to low ammonia emission from urea and elevated nitrate leaching from CAN.

- The efficiency of urean was less than that of CAN which also was attributed to ammonia emission. There was a large variation in effectiveness of urean due to the high impact of weather conditions on ammonia emission.

Bussink \& Oenema (1996) examined the efficiency of urea and CAN applied to grassland in the Netherlands and parts of the UK (Northern Ireland and England). In the Netherlands, the apparent yield of grassland treated with urea was on average 92 and $86 \%$ of CAN on sand and clay soils, respectively. There were no differences observed between urea and CAN on peat soils. In England and N. Ireland, the apparent yield of grassland with urea was the same as CAN during the first grass cut, but $97 \%$ in N. Ireland and $91 \%$ in England for the second cut. It was concluded that rainfall strongly effected the agronomic $\mathrm{N}$ use efficiency of fertilizers and that differences between the three countries could be attributed to differences in rainfall. It was calculated that application of urea to grassland in the Netherlands was more economically profitable when rainfall exceeded $6 \mathrm{~mm}$ within three days following application at the first cut and $9.5 \mathrm{~mm}$ within three days following application at the second cut.

Den Boer et al. (2011) produced a review of mineral $\mathrm{N}$ fertilizers which was partly based on the paper by Van Burg et al. (1982). The authors concluded that:

- Fertilizers based on nitrate and ammonium have a higher efficiency than those based on ammonium and urea.

- The average efficiency of urea compared to CAN is $90 \%$ and of urea with an urease inhibitor, $95 \%$.

- Fertilizers in solid form (prills or granules) have a higher yield and $\mathrm{N}$ uptake than liquid fertilizers. 
- The efficiency of liquid urea based fertilizers, including urean, is lower than that of liquid ammonium nitrate.

- The efficiency of ammonium based fertilizers with an added nitrification inhibitor is higher than CAN at the first dressing in early spring. This is especially the case for wet conditions that promote nitrate leaching and denitrification of nitrate applied with CAN.

A series of field experiments were carried out in 2004 and 2005 in the UK during which the crop response to different mineral fertilizers was determined. The main conclusions of these field experiments were (Dampney et al., 2006):

- Granular urea was commonly a less efficient source of $\mathrm{N}$ for winter cereal crop uptake than ammonia nitrate. This was most likely due to ammonia volatilisation. Use of granular urea in practice would justify around $20 \%$ higher $\mathrm{N}$ application rates to achieve the same cereal crop yield and quality.

- Differences in early spring between urean and ammonia nitrate applied to silage crops were small. This was probably due to significant rainfall just after $\mathrm{N}$ application.

- Liquid urean was a less efficient source of fertilizer- $\mathrm{N}$ for winter cereals than granular urea. Use in practice would justify around $30 \%$ higher $\mathrm{N}$ application rates.

- Addition of urease inhibitor (nBTPT, trade name Agrotain) appeared to improve the efficiency of urea based fertilizers.

Bhogal et al. (2003) summarized the main results of experiments carried out in the UK before 2000 and obtained similar results to Dampney (2006), i.e., there is a variable and on average lower $\mathrm{N}$ efficiency for urea and urean compared to CAN.

Forestal et al. (2017) reported that there was a tendency that grassland yields in Ireland were slightly higher when urea was applied in spring compared with CAN (103.5\% of CAN yield) and that summer yields following urea application were slightly lower than CAN ( $98.4 \%$ of CAN yield). There was no significant difference in annual grassland yield when CAN, urea and urea + NBPT were used throughout the growing season. The $\mathrm{N}$ offtake was higher for CAN and urea + NBPT than for urea alone in three of the five experiments (Table 7). This was attributed to a higher ammonia emission from urea.

Table 7 The main effects of fertilizer type on $N$ offtake ( $k g N$ per ha per yr) averaged across $N$ rates and harvest dates (Forestal et al., 2017).

\begin{tabular}{lccccc} 
Fertilizer type & \multicolumn{3}{c}{ Location and year } \\
\cline { 2 - 6 } & Johnstown & Moorepark & Johnstown & Moorepark \\
& Castle 2013 & 2013 & Castle 2014 & 2013 & 2014 \\
CAN & $58.9 \mathrm{a}^{\mathrm{a}}$ & $76.9 \mathrm{a}$ & $62.7 \mathrm{a}$ & 78.9 & 76.4 \\
\hline Urea & $53.5 \mathrm{~b}$ & $74.2 \mathrm{~b}$ & $56.7 \mathrm{~b}$ & 53.9 \\
\hline Urea + NBPT & $57.0 \mathrm{a}$ & $77.3 \mathrm{a}$ & $62.2 \mathrm{a}$ & 79.6 & 1.82 \\
\hline Standard error of mean & 1.93 & 1.16 & 1.67 & 1.07 \\
\hline
\end{tabular}

a $\mathrm{N}$ offtake values with different letters within columns are significantly different according to $F$-protected L.S.D. test $(P \leq 0.05)$.

Van Geel et al. (2011) presents a desk study on $\mathrm{N}$ fertilization strategies for potatoes. The paper summarises the results of different studies on the effect of $\mathrm{N}$ fertilizer types:

- Liquid fertilizers showed no higher efficiency than solid fertilizers in general. Liquid fertilizer may have a slightly higher $\mathrm{N}$ efficiency under dry conditions where irrigation is not possible.

- Cultan (Controlled uptake long-term ammonium nutrition; urea and ammonium sulphate solution) application did not result in higher yields than CAN.

- Potato yields were on average higher with CAN application than with urean or urean with an added urease inhibitor.

Postma et al. (2009) carried out field experiments with potatoes showing that, on average, the yields obtained with new types of fertilizer (including ammonium fertilizer with nitrification 
inhibitor, liquid urea based fertilizer, and slow release fertilizer) and new fertilization strategies were similar to that of CAN (yield differences of $1-2 \%$ ).

\subsection{Nitrogen use efficiency of manures}

The $\mathrm{N}$ use efficiency of manure is on average lower than that of mineral fertilizers. This is mainly because a part of the $\mathrm{N}$ in manure is present as organic $\mathrm{N}$ and because of the ammonia emission from manure. Only part of the organic $\mathrm{N}$ will be mineralised during the growing season to mineral $\mathrm{N}$ available for plant uptake. In addition, organic $\mathrm{N}$ will be mineralised in the years following application. Therefore, the $\mathrm{N}$ use efficiency of manure will improve with time. Ammonia emission starts immediately after manure application and will continue for a few days. Losses of ammonia from manure range from $3 \%$ of the mineral $\mathrm{N}$ in slurry injected deep into soil to more than $70 \%$ for broadcast slurry (Table 8 ).

The relative $\mathrm{N}$ use efficiency of cattle slurry to CAN applied to grassland in the Netherlands with a low ammonia emission application technique is about 50 to $60 \%$ ( $1^{\text {st }}$ year) and $80 \%$ (long-term) (Schröder et al., 2008; CBGV, 2017). The values for arable land are somewhat lower because the $\mathrm{N}$ uptake period of arable crops is shorter than that of grassland. The $\mathrm{N}$ efficiency of pig slurry is somewhat higher than that of cattle slurry because the mineral $\mathrm{N}$ fraction of total $\mathrm{N}$ is higher in pig slurry than in cattle slurry. The review of Webb et al. (2013) examining relative $\mathrm{N}$ efficiency of manures in the EU shows low values for some countries (less than $50 \%$ ). This is because manures are broadcast in many countries and the $\mathrm{N}$ efficiency of broadcast manures is much smaller than that of injected or incorporated manure (Huijsmans et al., 2015).

Table 8 Emission factors for ammonia with manure application used for calculation of ammonia emission in the Netherlands, in \% of ammoniacal nitrogen (Van Bruggen et al., 2017).

\begin{tabular}{lr}
\hline Grassland & 19.0 \\
\hline sod injector (in trenches in the soil) & 22.5 \\
\hline slurry tanker (partly in trenches in the soil and partly on the soil) & 26.0 \\
\hline spreader (in strips on the soil) & 74.0 \\
\hline Above ground & 2.0 \\
\hline & 24.0 \\
\hline Arable land & 30.0 \\
\hline manure injection & 36.0 \\
\hline sod injector (in trenches in the soil) & 22.0 \\
\hline slurry tanker (partly in trenches in the soil and partly on the soil) & 46.0 \\
\hline spreader (in strips on the soil) & 69.0 \\
\hline incorporated in 1 operation & \\
\hline above ground manure and sewage sludge & \\
\hline
\end{tabular}

\subsection{Acidification}

Transformations of $\mathrm{N}$ are an important source and sink of hydrogen ions or protons (Table 9). Acidification (generation of protons) reduces the fertility of the soil (decreases the availability of nutrients such as phosphorus, calcium, magnesium and molybdenum), affects microbial transformations in the soil, and causes the release of toxic compounds including aluminium and manganese (e.g. Bolan et al., 2003). This may cause a depression of crop growth and yields. Low soil $\mathrm{pH}$ promotes the production of $\mathrm{N}_{2} \mathrm{O}$ during nitrification and denitrification (Section 3.2.5).

Ammonium based fertilisers acidify soils as a result of a combination of nitrification, ammonium uptake by plants, and/or ammonia volatilization (Table 9). Nitrate based fertilizers increase the $\mathrm{pH}$ of 
soils due to a combination of nitrate uptake by plants and/or denitrification. In addition to the type of $\mathrm{N}$ fertiliser, soil acidification is dependent on crop type, soil type, weather conditions (leaching) and other $\mathrm{N}$ sources (Bolan et al., 2003). The acidifying effect of fertilizers applied to agricultural soils can be estimated from their chemical composition in combination with a quantification of the nitrogen cycle in the agricultural system under consideration. In the Netherlands, the acidifying effect of fertilizers is estimated using an ionic balance equation referred to as the 'Pierre-Sluijsmans equation' (Harmsen et al., 1990). Table 10 shows the acidifying effects of several $\mathrm{N}$ fertilizers. Manures contain high ammonium concentrations which have an acidifying effect either through uptake or nitrification. Organic $\mathrm{N}$ in manure leads to alkalinisation if it is mineralized. The total effect of manure on acidification depends on rates of inputs and uptake of cations and anions by the crop, specifically $\mathrm{NH}_{4}$ and $\mathrm{NO}_{3}$, and the rate of denitrification affecting nitrate leaching.

Liming is used to decrease soil acidification and to optimize plant growth in carbonate free soils. The major sources of lime used in agriculture are limestone $\left(\mathrm{CaCO}_{3}\right)$ and dolomite $\left(\mathrm{CaMgCO}_{3}\right)$. However, other compounds may also reduce soil acidification (burned lime, rock phosphate, sugar beet pulp). Dissolution of lime in soils leads to dissolution of carbonates and release of $\mathrm{CO}_{2}$. Countries are obliged to report the $\mathrm{CO}_{2}$ emission of limestone and dolomite used in agriculture in annual inventories delivered to the UNFCCC. The method used in the Netherlands is described by Vonk et al. (2018). Lime use in agriculture produces relatively small amounts of $\mathrm{CO}_{2}$, much smaller than the $\mathrm{N}_{2} \mathrm{O}$ emission from agriculture, for example.

Table 9 Generation (acidification) and consumption (alkalinisation) of protons $\left(\mathrm{H}^{+}\right)$during the $\mathrm{N}$ transformation processes (Velthof et al., 2011).

\begin{tabular}{lll} 
Process & Reaction & \\
Biological N-fixation & $4 \mathrm{ROH}+2 \mathrm{~N}_{2}+3 \mathrm{CH}_{2} \mathrm{O} \rightarrow 4 \mathrm{RNH}_{2}+3 \mathrm{CO}_{2}+\mathrm{H}_{2} \mathrm{O}$ & $\mathrm{mol} / \mathrm{mol} \mathrm{N}$ \\
\hline Mineralization of organic $\mathrm{N}$ & $\mathrm{RNH}_{2}+\mathrm{H}_{2} \mathrm{O}+\mathrm{H}^{+} \rightarrow \mathrm{ROH}+\mathrm{NH}_{4}^{+}$ & -1 \\
\hline Urea hydrolysis & $\left(\mathrm{NH}_{2}\right)_{2} \mathrm{CO}+3 \mathrm{H}_{2} \mathrm{O} \rightarrow 2 \mathrm{NH}_{4}^{+}+2 \mathrm{OH}^{-}+\mathrm{CO}_{2}$ & -1 \\
\hline Nitrification & $\mathrm{NH}_{4}^{+}+2 \mathrm{O}_{2} \rightarrow \mathrm{NO}_{3}^{-}+2 \mathrm{H}^{+}+\mathrm{H}_{2} \mathrm{O}$ & +2 \\
\hline Ammonium assimilation & $\mathrm{ROH}+\mathrm{NH}_{4}^{+} \rightarrow \mathrm{RNH}_{2}+\mathrm{H}_{2} \mathrm{O}+\mathrm{H}^{+}$ & +1 \\
\hline Nitrate assimilation & $\mathrm{ROH}+\mathrm{NO}_{3}^{-}+\mathrm{H}^{+}+2 \mathrm{CH}_{2} \mathrm{O} \rightarrow \mathrm{RNH}_{2}+2 \mathrm{CO}_{2}+2 \mathrm{H}_{2} \mathrm{O}$ & -1 \\
\hline Ammonia volatilization & $\mathrm{NH}_{4}^{+} \rightarrow \mathrm{NH}_{3}+\mathrm{H}^{+}$ & +1 \\
\hline Denitrification & $5 \mathrm{CH}_{2} \mathrm{O}+4 \mathrm{NO}_{3}^{-}+4 \mathrm{H}^{+} \rightarrow 2 \mathrm{~N}_{2}+5 \mathrm{CO}_{2}+7 \mathrm{H}_{2} \mathrm{O}$ & -1 \\
\hline
\end{tabular}

$1 \mathrm{R}=$ in the reaction mean organic $\mathrm{C}$ compounds.

Table 10 Effect of fertilizer type on soil pH, expressed in base equivalent in $\mathrm{kg}$ CaO per $100 \mathrm{~kg}$ fertilizer (NMI, 2000). Negative values indicate acidification and positive values alkalinisation of the soil.

\begin{tabular}{|c|c|c|}
\hline \multirow[t]{2}{*}{ Fertilizer type } & \multicolumn{2}{|c|}{ kg CaO per 100 kg fertilizer } \\
\hline & Arable land & Grassland \\
\hline Ammonium sulphate & -63 & -59 \\
\hline Calcium ammonium nitrate & -15 & -10 \\
\hline Magnesamon & -2 & 3 \\
\hline Potassium nitrate & 11 & 14 \\
\hline Urea & -46 & -37 \\
\hline Urean & -30 & -24 \\
\hline
\end{tabular}

* depending on the composition of the fertilizer 


\subsection{Conclusions}

- Fertilizers based on nitrate and ammonium have, on average, a higher $\mathrm{N}$ efficiency than ammonium and urea fertilizers. The average efficiency of urea and urea with a urease inhibitor is $90 \%$ and $95 \%$ of CAN, respectively.

- Application of fertilizers in solid form (prills or granules) result in a higher yield and $\mathrm{N}$ uptake than application of liquid fertilizers.

- The higher $\mathrm{N}$ use of efficiency of CAN compared to urea and urean is due to higher ammonia emission from urea and urean. The differences are smallest during wet conditions (low risk of ammonia emission). The $\mathrm{N}$ efficiency of urea is higher than that of CAN in wet conditions in early spring. This is probably due to a low ammonia emission from urea and elevated nitrate leaching from CAN during these wet conditions.

- The $\mathrm{N}$ use efficiency of manure is on average lower than that of mineral fertilizers. This is mainly because a part of the $\mathrm{N}$ in manure is present as organic $\mathrm{N}$ and because of the ammonia emission from manure. Only part of the organic $\mathrm{N}$ will be mineralised during the growing season to mineral $\mathrm{N}$ available for plant uptake. In addition, organic $\mathrm{N}$ will be mineralised in the years following application. Therefore, the $\mathrm{N}$ use efficiency of manure will improve with time. Application of manure with a low ammonia emission application technique increases the $\mathrm{N}$ use efficiency relative to broadcasting of manure.

- Repeated application of ammonium fertilizer acidifies soil more strongly than ammonium nitrate fertilizer application. Acidification negatively affects the mineral composition of grass (lower magnesium and calcium contents) and the botanical composition of the sward. Liming is required to maintain the soil $\mathrm{pH}$ in this case. 


\section{$5 \quad$ Effects of mineral fertilizers and manures on nitrous oxide emission}

\subsection{Studies with different fertilizer types in the Netherlands}

\subsubsection{Field experiments}

Velthof et al. (1997) compared the effects of different fertilizers and manures following their application to grassland in three experiments in the Netherlands (Table 11). Emissions were very low following applications on grassland with clay soil $(<0.1 \%)$. However, the two experiments on sandy soil were carried out under extremely wet conditions as there was heavy rainfall in the days after application in both cases. It was clear that the $\mathrm{N}_{2} \mathrm{O}$ emission from the nitrate containing fertilizers, CAN and calcium nitrate, were much higher than that from ammonium sulphate, urea and cattle slurry. Measurements of denitrification showed that the high $\mathrm{N}_{2} \mathrm{O}$ emission from the nitrate based fertilizers was due to denitrification (Table 11). The amount of nitrate added with calcium nitrate was twice that of CAN, but the difference in $\mathrm{N}_{2} \mathrm{O}$ emission factor was less than a factor 2 between these fertilizers. More specifically, in one experiment there was no effect and in the other experiment a factor 1.4 difference was calculated.

Table 11 Emission of $\mathrm{N}_{2} \mathrm{O}$ and total $\mathrm{N}$ losses by denitrification from grassland (in \% of applied $\mathrm{N}$ ) after application of different types of fertilizers or manure (at $80 \mathrm{~kg} \mathrm{~N}$ per ha) in three experiments lasting about three weeks (Velthof et al., 1997).

\begin{tabular}{|c|c|c|c|c|c|}
\hline \multirow[t]{2}{*}{ Fertilizer } & \multirow{2}{*}{$\begin{array}{l}\text { Clay soil, } \\
13 \mathrm{~mm} \text { rain; } \\
6.0^{\circ} \mathrm{C} \\
\mathrm{N}_{2} \mathrm{O}\end{array}$} & \multicolumn{2}{|c|}{$\begin{array}{l}\text { Sandy soil } \\
42 \mathrm{~mm} \text { rain; } 8.2^{\circ} \mathrm{C}\end{array}$} & \multicolumn{2}{|c|}{$\begin{array}{c}\text { Sandy soil } \\
68 \mathrm{~mm} \text { rain; } 16.0^{\circ} \mathrm{C}\end{array}$} \\
\hline & & & & & \\
\hline Calcium ammonium nitrate & $<0.1$ & 5.2 & 14.1 & 8.3 & 8.3 \\
\hline Calcium nitrate & $<0.1$ & 5.2 & 12.4 & 12.0 & 10.5 \\
\hline $\begin{array}{l}\text { Ammonium sulphate }+ \text { nitrification } \\
\text { inhibitor DCD }\end{array}$ & - & $<0.1$ & 0.2 & 0.1 & 0.0 \\
\hline Urea & $<0.1$ & $<0.1$ & 1.1 & 0.7 & 1.9 \\
\hline Cattle slurry; surface-applied & - & $<0.1$ & 0.4 & $<0.1$ & 0.4 \\
\hline
\end{tabular}

The $\mathrm{N}_{2} \mathrm{O}$ emission from CAN was compared with cattle slurry (grassland) and pig slurry (maize fields) in field experiments carried out by Velthof and Mosquera (2011b). The main results (Table 12) are:

- The $\mathrm{N}_{2} \mathrm{O}$ emission was higher for CAN than for cattle slurry on grassland. This suggests that the presence of nitrate in CAN was an important factor controlling $\mathrm{N}_{2} \mathrm{O}$ emission from grassland.

- The $\mathrm{N}_{2} \mathrm{O}$ emission from CAN was lower than from pig slurry on maize fields. This suggests that the presence of nitrate in CAN was not a dominating factor controlling $\mathrm{N}_{2} \mathrm{O}$ emission on arable land. The much higher $\mathrm{N}_{2} \mathrm{O}$ emission from pig slurry on maize fields was most probably due to the addition of available carbon to the slurry. Carbon is an energy source for denitrifying bacteria; see Section 3.2.2. Van Groenigen et al. (2004) also found a higher $\mathrm{N}_{2} \mathrm{O}$ emission from cattle slurry than from CAN applied to maize fields in the Netherlands which was attributed to the effect of carbon addition to the soil with cattle slurry.

- Injection of slurry increased $\mathrm{N}_{2} \mathrm{O}$ emission which was most likely due to a combination of two factors: injection reduces ammonia emission so that more mineral $\mathrm{N}$ remains in the soil, and oxygen concentrations near soil where slurry is injected is lower than concentrations near surface applied slurry. 
Table 12 Average $\mathrm{N}_{2} \mathrm{O}$ emission factors, \% of $\mathrm{N}$ applied (Velthof and Mosquera, 2011b).

\begin{tabular}{|c|c|c|c|}
\hline \multirow[t]{2}{*}{ Object } & \multicolumn{3}{|c|}{$\mathrm{N}_{2} \mathrm{O}$ emission factor, $\%$ of $\mathrm{N}$} \\
\hline & $\begin{array}{l}\text { Grassland } \\
\text { clay soil }\end{array}$ & $\begin{array}{l}\text { Grassland } \\
\text { sandy soil }\end{array}$ & $\begin{array}{c}\text { Maize fields } \\
\text { sandy soil }\end{array}$ \\
\hline Cattle slurry; shallow injection & 0.3 & 0.5 & 0.9 \\
\hline Cattle slurry; surface applied & 0.1 & 0.1 & 0.4 \\
\hline Pig slurry; injected & $*$ & $*$ & 3.6 \\
\hline Pig slurry; surface applied & $*$ & $*$ & 0.9 \\
\hline
\end{tabular}

Figure 17 shows the pattern of $\mathrm{N}_{2} \mathrm{O}$ emission on grassland and maize fields. On maize fields there is one peak of $\mathrm{N}_{2} \mathrm{O}$ per year just after $\mathrm{N}$ application which can last several weeks. The magnitude and length of the peak is affected by rainfall. This can be seen when the three years in Figure 17 are compared. The same amount of $\mathrm{N}$ was applied during each year, but emissions were much higher in the relatively wet summer of 2007 than in the drier years of 2008 and 2009. On grassland, the peaks are much shorter, i.e., from several days to 2-3 weeks, and there are more peaks in single years. This is due to the multiple $\mathrm{N}$ dressings causing several peaks of $\mathrm{N} 2 \mathrm{O}$ within years, and the rapid $\mathrm{N}$ uptake by grass and/or $\mathrm{N}$ immobilization in grassland soil indicated by narrow peaks of $\mathrm{N} 2 \mathrm{O}$ after $\mathrm{N}$ application. The period during which mineral $\mathrm{N}$ content in the soil is elevated after $\mathrm{N}$ application, when the risk on N2O emission is highest, is much shorter on grassland than on maize fields. Clearly, only a few peaks of $\mathrm{N} 2 \mathrm{O}$ emission during single years occur on grassland and maize fields (and other arable crops). These are observed during wet periods in the first weeks after $\mathrm{N}$ application. Mitigation strategies should focus on these periods where the risk of $\mathrm{N}_{2} \mathrm{O}$ emission is highest. 

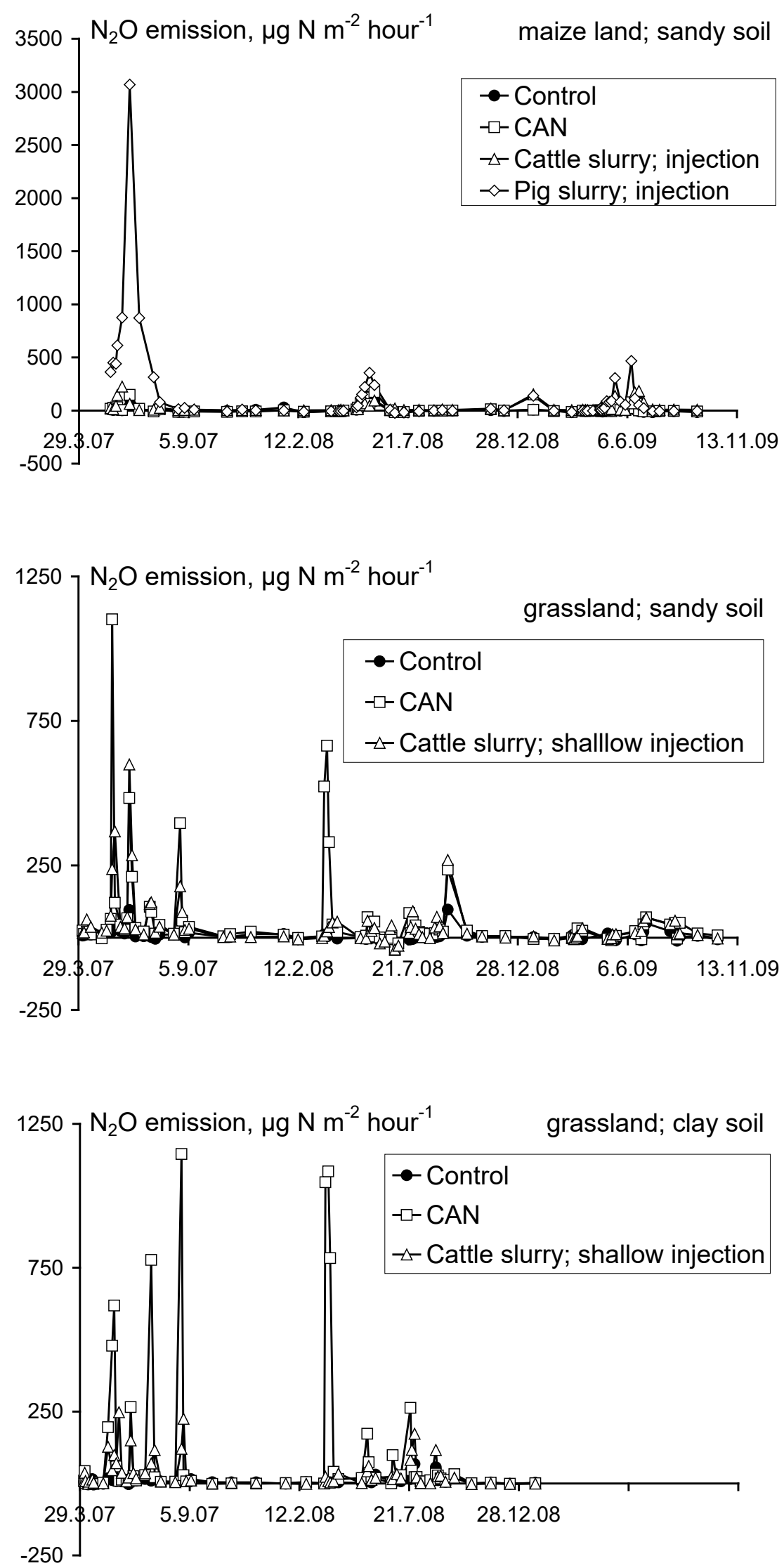

Figure 17 Fluxes of $\mathrm{N}_{2} \mathrm{O}$ from unfertilized control, CAN, and (shallow) injected slurry on maize fields on sand (upper figure), grassland on sand (middle figure) and clay soil (lower figure); Velthof and Mosquera, $2011 b$. 


\subsubsection{Laboratory experiments}

The results of an incubation experiment where identical conditions were applied in each treatment showed very large differences between manure types (Figure 18). Emission of $\mathrm{N}_{2} \mathrm{O}$ was highest after application of slurry from fattening pigs and sows. Animal manures are a mixture of mineral $\mathrm{N}$, salts, water, and easily mineralizable and resistant organic $\mathrm{N}$ and $\mathrm{C}$ compounds. There are large differences in composition between animal manures due to differences in animal species and nutrition. These differences in composition result in large differences in $\mathrm{N}_{2} \mathrm{O}$ emission. In general, the degradability of organic $\mathrm{C}$ in pig slurry is higher than that of cattle slurry and poultry manure. This is probably a major cause of the higher $\mathrm{N}_{2} \mathrm{O}$ emission from pig slurries.

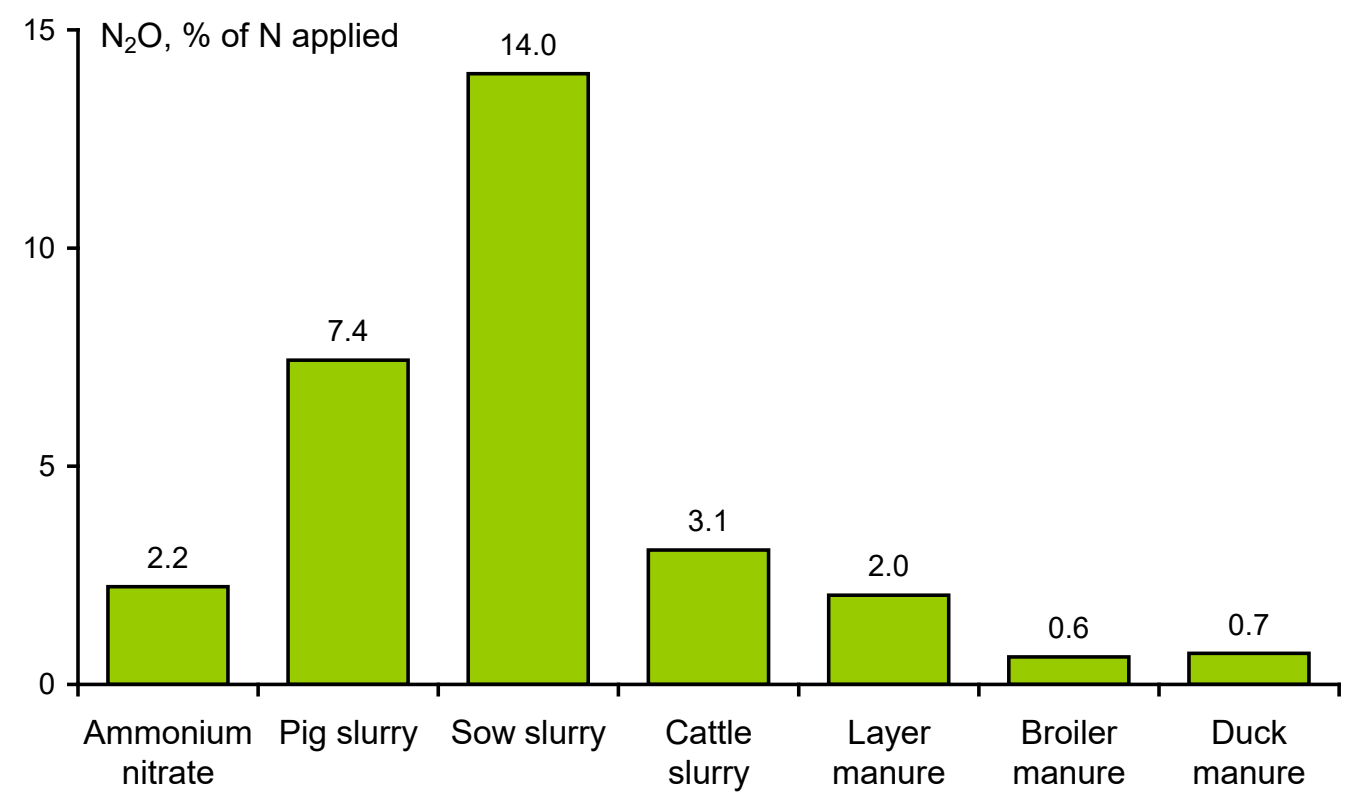

Figure 18 Emission of $\mathrm{N}_{2} \mathrm{O}$ from ammonium nitrate and several manure types in an incubation experiment by Velthof et al. (2003).

Velthof and Hummelink (2011) carried out several incubation experiments under controlled conditions. These types of study give a good insight into processes and controlling factors, but cannot be directly translated to the field because of differing conditions, e.g., crop presence. The experiments were carried out at $20^{\circ} \mathrm{C}$ and at field capacity. Field capacity is defined as the soil moisture content after excess water has percolated into deeper soil layers following rainfall.

CAN showed higher $\mathrm{N}_{2} \mathrm{O}$ emission than urea, urean and pig slurry for sand and peat, and lower $\mathrm{N}_{2} \mathrm{O}$ emission for clay on grassland soils (Figure 19). This reveals the complexity of predicting $\mathrm{N}_{2} \mathrm{O}$ emissions resulting from the many factors that play a role in controlling $\mathrm{N}_{2} \mathrm{O}$ emissions.

Incorporation of fertilizers and manures increased the emission of $\mathrm{N}_{2} \mathrm{O}$ in all cases except for urean (Figure 20). This is because oxygen concentration is lower in the soil than on the soil surface. Moreover, ammonia emission is higher from surface applied manures and mineral $\mathrm{N}$ content in soil is lower after surface application in comparison with incorporation methods. The $\mathrm{N}_{2} \mathrm{O}$ emission of CAN was lowest on arable soil indicating that denitrification was a less important source of $\mathrm{N}_{2} \mathrm{O}$ than nitrification under these experimental conditions and/or that available $\mathrm{C}$ was limiting denitrification in this experiment. The higher $\mathrm{N}_{2} \mathrm{O}$ emission from urea, urean and mineral concentrate may be related to inhibition of nitrification resulting from high ammonia concentration. Ammonia toxicity inhibits the oxidation of nitrite to nitrate during nitrification resulting in an accumulation of nitrite and potential $\mathrm{N}_{2} \mathrm{O}$ production (see also Section 3.1.2.2 Chemical denitrification in the previous Chapter). 


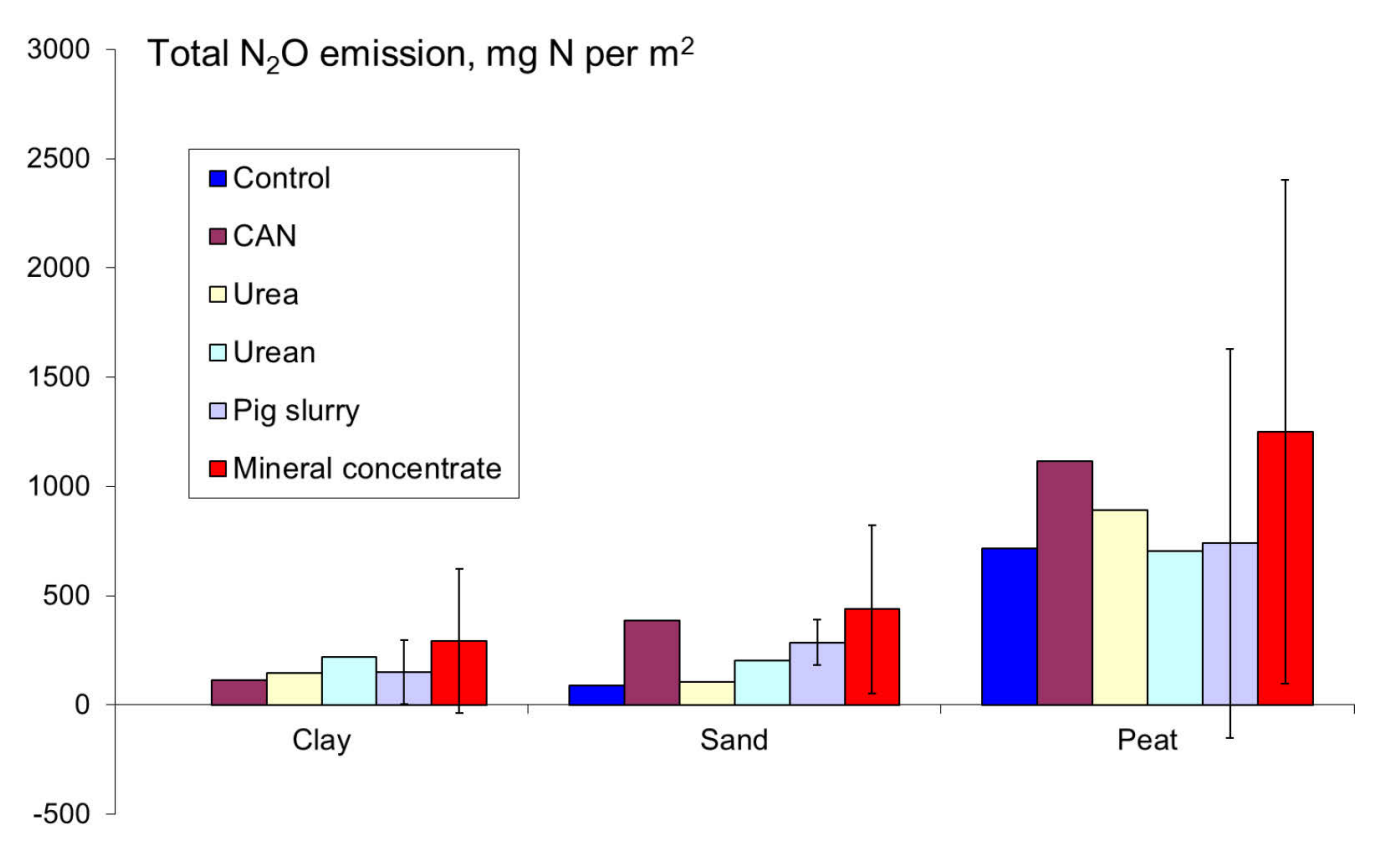

Figure 19 Total $\mathrm{N}_{2} \mathrm{O}$ emission from surface applied CAN, urea, urean, injected pig slurry, and injected mineral concentrate of the liquid fraction of pig slurry, after application to grass sward on clay, sand, and peat soil in a pot experiment under controlled conditions. The results from pig slurry and mineral concentrates are the average \pm standard deviation of four manure treatment installations (Velthof and Hummelink, 2011).

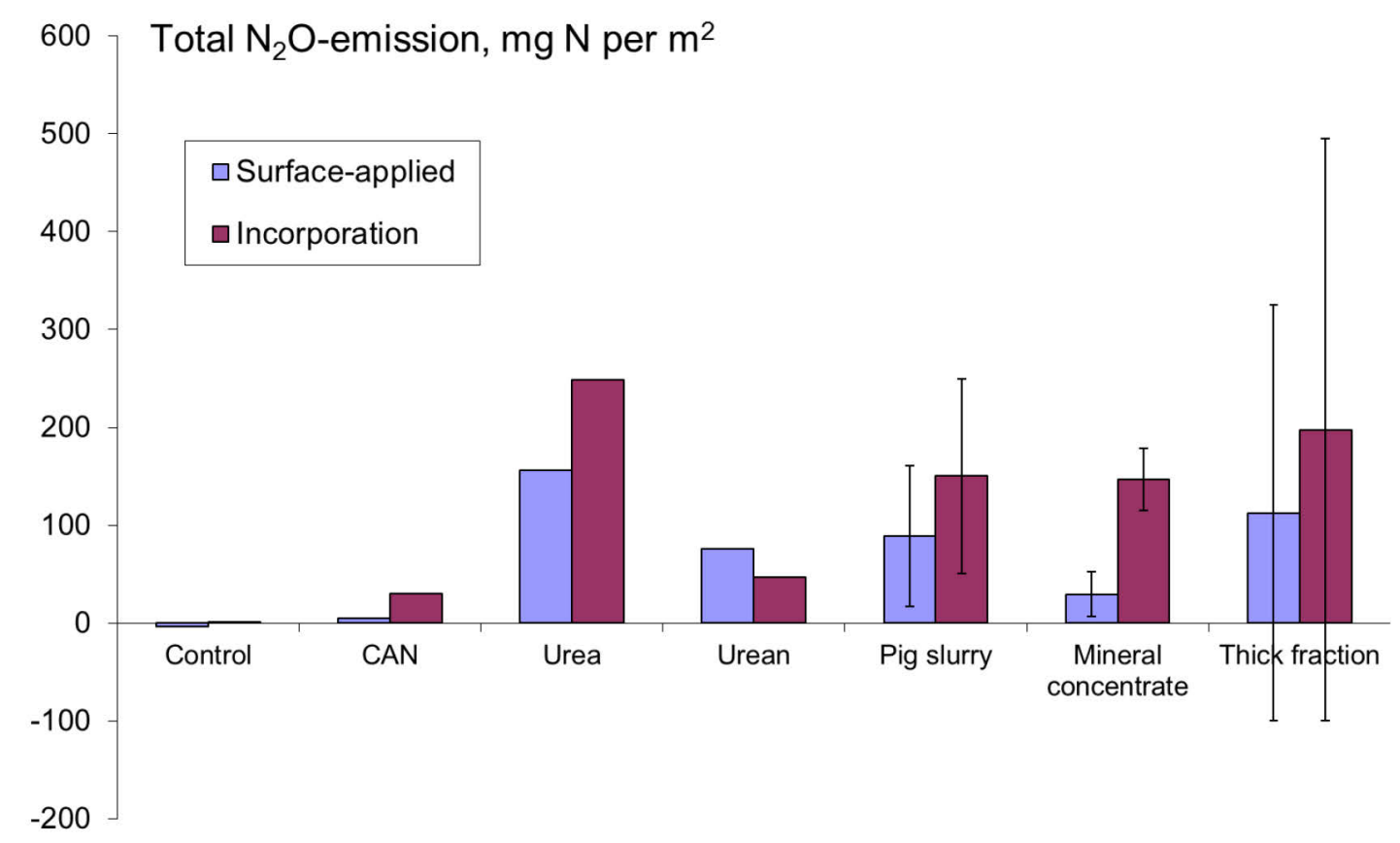

Figure 20 Total $\mathrm{N}_{2} \mathrm{O}$ emission from CAN, urea, urean, pig slurry, mineral concentrate of the liquid fraction of pig slurry, and the thick fraction of pig slurry after both surface application and incorporation to arable sandy soil in an incubation study under controlled conditions. The results from pig slurry, mineral concentrates, and thick fraction are the average \pm standard deviation of four manure treatment installations (Velthof and Hummelink, 2011). 


\subsection{Studies outside the Netherlands}

A literature study was carried by Velthof and Mosquera (2011a) to summarize the results of studies performed outside the Netherlands. The study focused on experiments in which emission factors of CAN and livestock manure were derived and included the effects of application technique. Urea was not included in this review study.

Table 13 presents a summary of the results of the literature study. The average emission factor for CAN on grassland was $0.7 \pm 0.2 \%$ and on arable land $0.7 \pm 0.3 \%$. Remarkably, the emission factor of ammonium nitrate was much higher than that of CAN (2.3\% on grassland and $2.1 \%$ on arable land). The exact reason for this is not clear. It may suggest that the liming effect of CAN has decreased $\mathrm{N}_{2} \mathrm{O}$ emission. It is known that $\mathrm{N}_{2} \mathrm{O}$ emissions are relatively high when conditions are acidic (e.g. Russenes et al., 2016). However, the limited number of studies in which CAN was tested restricts our ability to come to firm conclusions. Currently, no studies exist where ammonium nitrate and CAN are tested together. The average emission factor for manures on grassland was $0.8 \pm 0.4 \%$ and that of arable land $0.6 \pm 0.1 \%$.

Velthof and Mosquera (2011a) summarized the results of studies carried out outside the Netherlands in which $\mathrm{N}_{2} \mathrm{O}$ emission factors of different fertilizers and manures were derived in the same experiment (Table 14). This gives a better indication of the difference in $\mathrm{N}_{2} \mathrm{O}$ emission between fertilizers because conditions are controlled. Emission of $\mathrm{N}_{2} \mathrm{O}$ from CAN was clearly higher than from cattle manure in three studies on grassland, lower than ammonium fertilizer in two studies and similar to cattle manure in one experiment. The three studies in which higher emissions were found for nitrate fertilizers were all carried out in the UK (Egginton \& Smith, 1986; Clayton et al., 1997).

Table 13 Summary of $\mathrm{N}_{2} \mathrm{O}-\mathrm{N}$ emission factors (in \% of $\mathrm{N}$ ) derived from literature excluding studies from the Netherlands (Velthof and Mosquera, 2011a). ${ }^{6}$

\begin{tabular}{|c|c|c|c|c|c|c|}
\hline Fertilizer & \multicolumn{3}{|c|}{ Grassland } & \multicolumn{3}{|c|}{ Arable land } \\
\hline Manures & 0.8 & 0.4 & 19 & 0.6 & 0.1 & 24 \\
\hline Pig manure & 0.3 & 0.1 & 4 & 0.8 & 0.2 & 7 \\
\hline Mineral fertilizers & 1.9 & 0.3 & 81 & 1.9 & 0.4 & 59 \\
\hline Ammonium nitrate & 2.3 & 0.3 & 42 & 2.1 & 0.4 & 48 \\
\hline Calcium ammonium nitrate & 0.7 & 0.2 & 7 & 0.7 & 0.3 & 7 \\
\hline Calcium, sodium of potassium nitrate & 2.3 & 0.9 & 20 & 1.4 & 0.9 & 2 \\
\hline
\end{tabular}

Roche et al. (2016) found no significant differences in $\mathrm{N}_{2} \mathrm{O}$ emissions between CAN and urea in a field study under spring barley in Ireland. Adding a nitrification inhibitor reduced $\mathrm{N}_{2} \mathrm{O}$ emission from urea, but an urease inhibitor did not reduce $\mathrm{N}_{2} \mathrm{O}$ emissions relative to CAN.

A study by Harty et al. (2016) in Ireland evaluated the impact of switching fertilizer formulation from CAN to urea based products on grassland (urea, urea + urease inhibitor N-(n-butyl) thiophosphoric triamide (NBPT), and urea + nitrification inhibitor dicyandiamide; DCD). The results showed that $\mathrm{N}_{2} \mathrm{O}$ emissions were highest for CAN, also when the indirect $\mathrm{N}_{2} \mathrm{O}$ emission from ammonia was

\footnotetext{
6 References: Abbasi and Adams (2000); Ambus et al. (2001); Anger et al. (2003); Arah et al. (1991); Ball et al. (2000); Burford et al. (1981); Chadwick et al. (2000); Christensen (1983), Clayton et al. (1994); Clayton et al. (1997); Clemens et al. (1997); Colbourn and Harper (1987); Colbourn et al. (1984); Conrad et al. (1983); Dobbie and Smith (2003a); Dobbie et al. (1999); Eggington and Smith (1986); Ellis et al. (1998); Glatzel and Stahr (2001); Goossens et al. (2001); Hénault et al. (1998a); Jambert et al. (1997); Jørgensen et al. (1997); Kaiser et al. (1996); Kaiser et al. (1998b); Kamp et al. (1998); McTaggart et al. (1997); Misselbrook et al. (1998); Mogge et al. (1999); Petersen (1999); Rodhe et al. (2006); Ryden (1981); Seiler and Conrad (1981); Skiba et al. (1992); Skiba et al. (1998); Slemr et al. (1984); Smith et al. (1998a, b); Van Cleemput et al. (1994); Webster and Dowdell (1982); Weslien et al. (1998); Wulf et al. (2002); Yamulki and Jarvis (2002); Yamulki et al.(1995).
} 
accounted for (Figure 21). The authors concluded that switching from CAN to stabilised urea formulations was found to be an effective strategy to reduce $\mathrm{N}_{2} \mathrm{O}$ emissions, particularly in wet, temperate grassland. This is in agreement with Velthof et al. (1997), Clayton et al. (1997), Dobbie and Smith (2003), Jones et al. (2007) and Smith et al. (2012). From a review of UK studies, Smith et al. (2012) concluded that there was some evidence of lower $\mathrm{N}_{2} \mathrm{O}$ emissions from urea than from ammonium nitrate or CAN. This is due to high $\mathrm{N}_{2} \mathrm{O}$ emissions from grassland when nitrate based fertilizers are applied during wet conditions. Nitrous oxide emission is lower for CAN and higher for urea than for nitrate based fertilizers during drier conditions.

Table 14 Results of studies in which different fertilizers and manure were applied, excluding studies from the Netherlands (Velthof and Mosquera, 2011a).

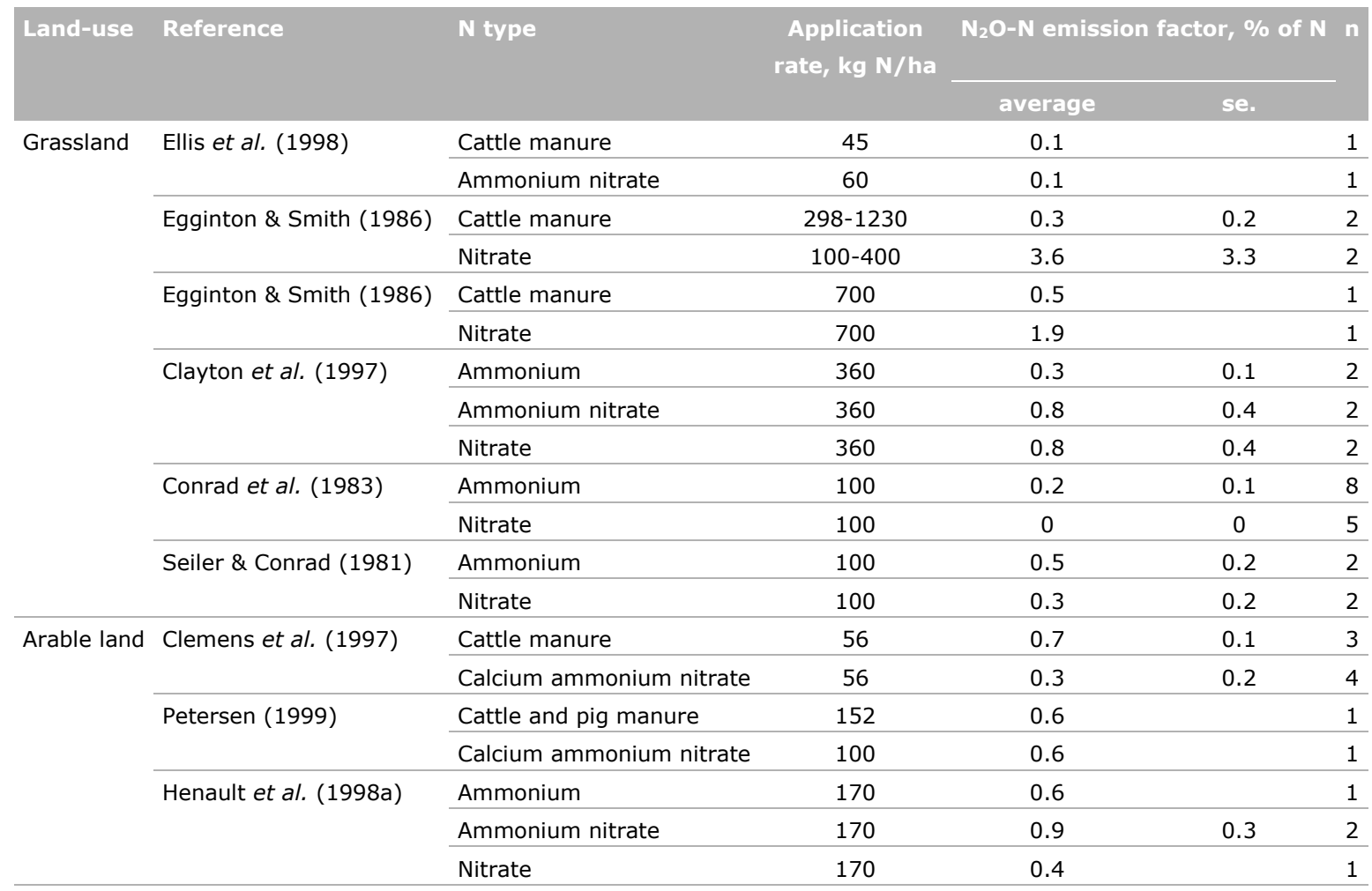

Measurements in the UK by Bell et al. (2015) showed a much higher $\mathrm{N}_{2} \mathrm{O}$ emission from arable cropping systems at a wet Scottish site than at drier English sites (Figure 22). Climate and soil mineral $\mathrm{N}$ influenced $\mathrm{N}_{2} \mathrm{O}$ emissions from arable land. There was no significant difference in $\mathrm{N}_{2} \mathrm{O}$ emission factor between urea and ammonium nitrate on arable land. Application of ammonium nitrate in more frequent smaller doses reduced emissions at all sites compared to one larger nitrogen application. Adding a nitrification inhibitor to ammonium nitrate significantly reduced $\mathrm{N}_{2} \mathrm{O}$ emission from these arable soils.

A study on winter wheat in northwest Germany by Lebener et al. (2014) concluded that nitrification was the predominant process for $\mathrm{N}_{2} \mathrm{O}$ production under mainly dry conditions. Under these conditions, urea and ammonium sulphate caused higher $\mathrm{N}_{2} \mathrm{O}$ emissions during the growth period compared to CAN. The emission factors based on one year for the three sites examined in this study were:

- Site 1: $0.51 \%$ urea, $0.32 \%$ ammonium sulphate and $0.23 \%$ CAN

- Site 2: $0.32 \%$ urea, $0.94 \%$ ammonium sulphate and $0.05 \%$ CAN

- Site 3: $0.34 \%$ urea, $0.38 \%$ ammonium sulphate and $0.37 \%$ CAN 


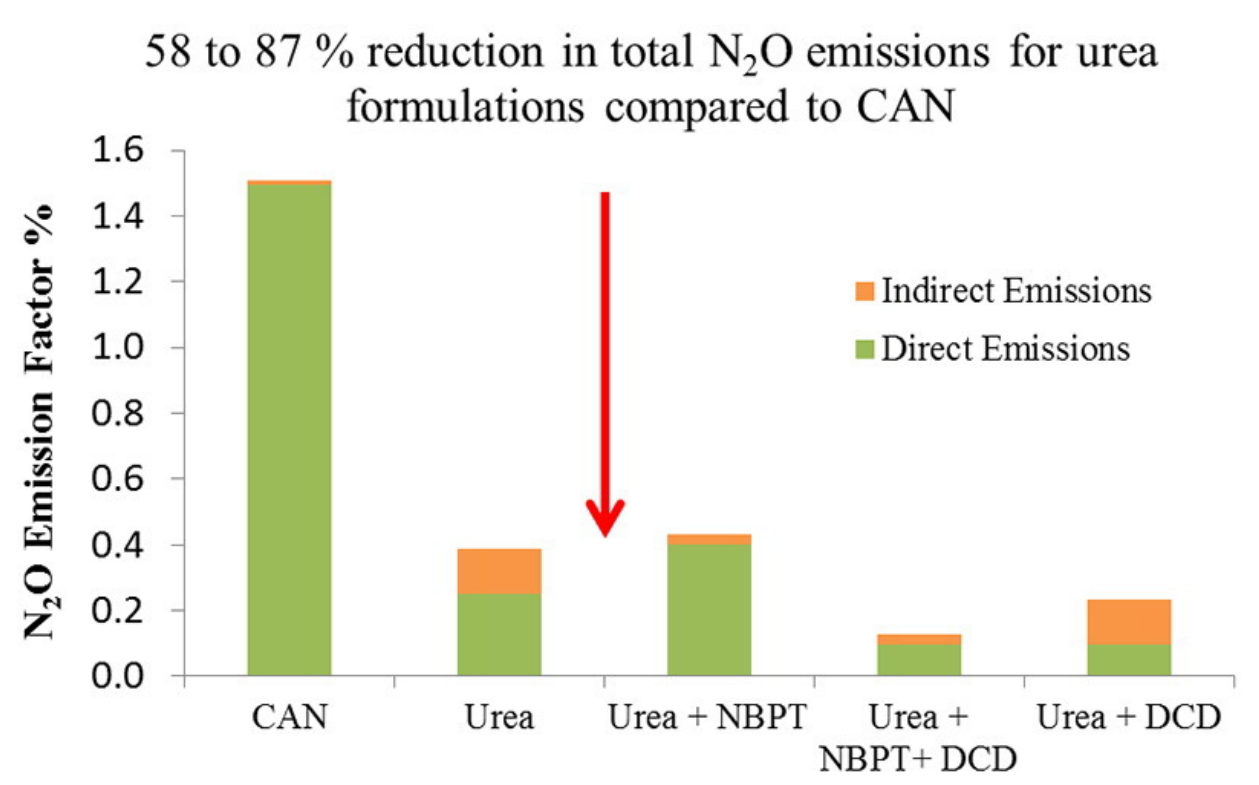

Figure 21 Emission factors of $\mathrm{N}_{2} \mathrm{O}$ from CAN, urea and urea with NBPT and/or DCD applied to grassland in Ireland (Harty et al., 2016).

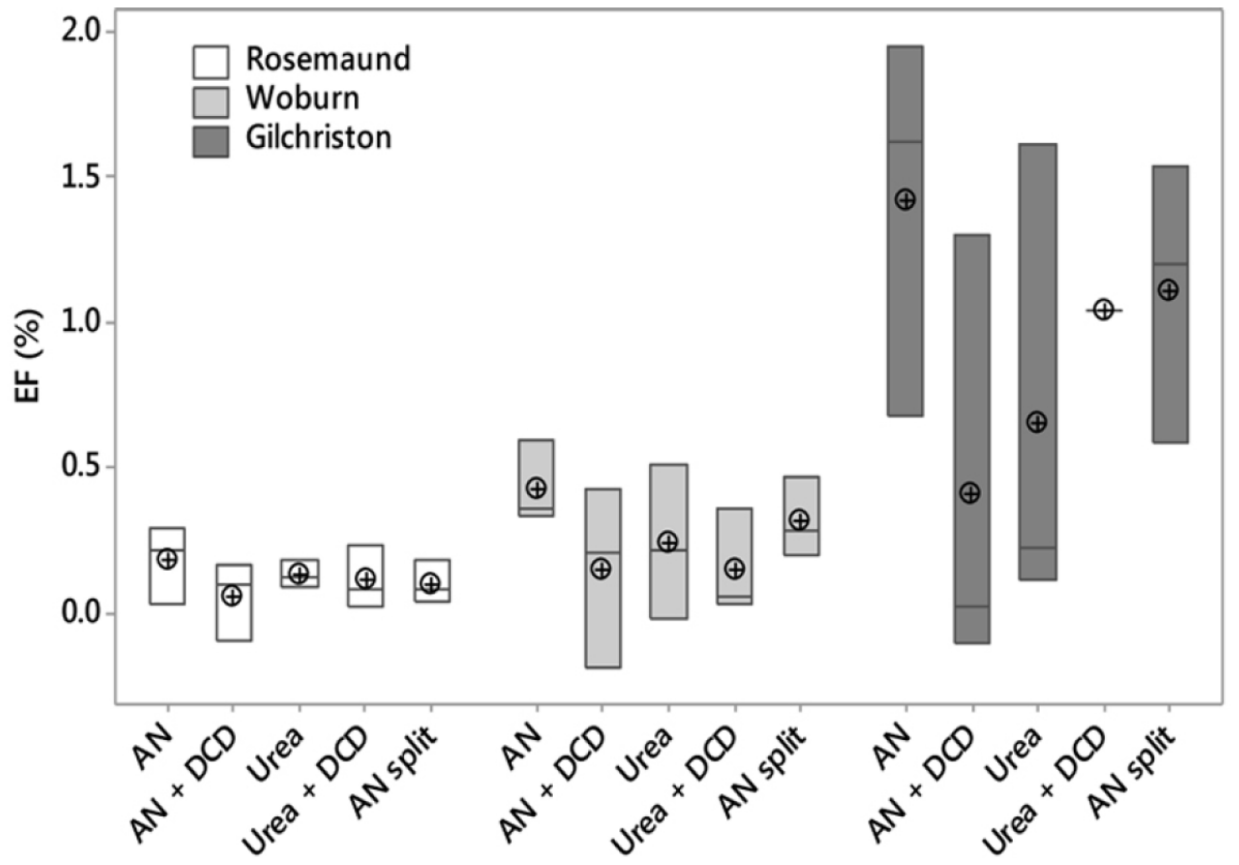

Figure 22 Emission factors of $\mathrm{N}_{2} \mathrm{O}$ from ammonium nitrate (AN) and urea for arable cropping systems at three sites in the UK (Gilchriston in Scotland and two sites in England). AN and urea were also applied with the nitrification inhibitor DCD. The $A N$ split indicates more frequent $N$ application in smaller dressings (Belle, 2015).

\subsection{Synthesis}

Statistical analyses on measurements of $\mathrm{N}_{2} \mathrm{O}$ emissions from the global database (Bouwman, 1996; Stehfest and Bouwman, 2006) showed no significant effect of fertilizer type on $\mathrm{N}_{2} \mathrm{O}$ emission. However, several studies in which different mineral fertilizers are compared in one experiment often show large differences between fertilizers (see previous paragraphs). Incubation studies show that differences in $\mathrm{N}_{2} \mathrm{O}$ emission between nitrate and ammonium based fertilizer are due to the soil 
moisture content (e.g. Pathak and Nedwell, 2001). The $\mathrm{N}_{2} \mathrm{O}$ emission from nitrate containing fertilizers is higher than from ammonium based fertilizers under wet conditions.

Studies on grassland soils point at higher $\mathrm{N}_{2} \mathrm{O}$ emissions from nitrate based fertilizers than from fertilizers that only contain ammonium, especially under wet conditions. The $\mathrm{N}_{2} \mathrm{O}$ emission from nitrate based fertilizer applied to grassland is also higher than from cattle slurries. It is clear that the denitrification capacity of grassland is high because of the large amount of easily degradable organic matter contents available at these sites. Adding nitrate to grassland during wet conditions or before rainfall events will increase the risk of high $\mathrm{N}_{2} \mathrm{O}$ emission.

Studies on arable soils point at similar or lower $\mathrm{N}_{2} \mathrm{O}$ emission from nitrate based fertilizers than urea and ammonium based fertilizers, especially under relatively dry conditions. The denitrification capacity of arable land is low because of the low easily degradable organic matter content at these sites. Urea may increase $\mathrm{N}_{2} \mathrm{O}$ emission during relatively dry conditions because of the ammonia toxicity of nitrifying bacteria which leads to nitrite accumulation. Application of livestock slurry increases the denitrification capacity of arable land. The emission of $\mathrm{N}_{2} \mathrm{O}$ from arable land is often higher for livestock slurry than for CAN. 


\section{Mitigation of nitrous oxide emission from fertilizers and manures}

\subsection{Nitrification inhibitors}

\subsubsection{Types of nitrification inhibitor}

Nitrification inhibitors inhibit the transformation of ammonium to nitrite by Nitrosomonas bacteria and thereby the production of $\mathrm{N}_{2} \mathrm{O}$ during nitrification (Figure 8). In addition, $\mathrm{N}_{2} \mathrm{O}$ production through denitrification of nitrate released during nitrification is also reduced when nitrification is inhibited.

Table 15 presents an overview of the nitrification inhibitors mentioned in literature. There are three important brands of nitrification inhibitors (Slangen and Kerkhoff, 1984; Chien et al., 2009; Trenkel, 2010; Kumar et al., 2015):

- 'ENTEC' inhibitors from BASF using 3,4-dimethyl pyrazole phosphate (DMPP) (Zerulla et al., 2001)(http://entecfertilizers.com.au/). Using the trade name 'Vizura', this inhibitor is sold as an additive for animal manure.

- 'N-serve' inhibitors using 2-chloro-6-(trichloromethyl) pyridine (Nitrapyrin) from DOW Chemical (http://research.ipni.net/page/RNAP-6379).

- 'Alzon' inhibitors using dicyandiamide (DCD) and/or $1 \mathrm{H}-1,2,4$ Triazol (DCD/TZ) from SKW Piesterwitz (http://www.skwp.de/). Using the trade name 'Piadin', these inhibitors are sold as an additive for animal manures (TZ, 3-MP). DCD is also added to controlled-release fertilizers (Chissosahi, Japan).

The following nitrification inhibitors can be traded in the EU according to the EU fertilizers Regulation 2003/2003:

- Dicyaandiamide (DCD) (Regulation EU nr. 1107/2008)

- Mixture of dicyaandiamide (DCD) and 1,2,4-triazool (TZ) (DCD/TZ) (Regulation EU nr. 223/2012)

- Mixture of 1,2,4-triazool (TZ) and 3-methylpyrazool (MP) (TZ/MP) (Regulation EU nr. 223/2012)

- 3,4-dimethyl pyrazole phosphate (DMPP) (Regulation EU nr. 1257/2014)

The main producers of nitrification inhibitors are BASF (Germany), SKW Piesterwitz (Germany), DOW Chemical (US), Koch (US) and Eurochem (DMPSA) (Switzerland). There are also several producers in Japan and India.

There are a large number of patented nitrification inhibitors. Subbarao (2013) gave an up to date overview of 85 substances where older references are quoted (Slangen \& Kerkhoff, 1984; Subbarao et al., 2006). 1403 patents can be found using the search term 'nitrification inhibitor' in the orbit patent database. The fact that 'nitrification inhibitor' is mentioned in a patent does not necessarily mean that the patent refers directly to a nitrification inhibitor. No attempt was made to assess whether these 1403 patents are all related to nitrification inhibitors as most patents are rather complex. The publication dates vary from 1964 to 2018 . The total number of patents in the years 1990, 2000 and 2010 were 76, 214 and 480, respectively. In total 945 patents are 'alive' and 458 patents are 'dead'. Of the 'dead' patents, 106 were 'revoked', 123 'expired' and 229 'lapsed'. The largest number of patents are found for (number of patents are indicated between brackets): Syngenta (185), Qingdao (60), BASF (36), SKW Piesteritz (29), Institute of Applied Ecology CAS $(19+23)$, Kurita (22), Dow chemical (19), and Koch (19).

New nitrification inhibitors are often well known substances in a slightly different form. For example, DMPSA (Pacholski et al., 2016) from Eurochem. DMPSA combines DMP with succinic acid with the result that DMP is only released if there is microbial degradation of succinic acid (Pacholski et al., 2016). Another example inhibitor is potassium thiosulfate which is similar to ammonium thiosulfate (ATS) but where potassium is used instead of ammonium (Cai et al., 2018). Relatively new 
approaches involve combinations of nitrification inhibitors with urease inhibitors in urea (Ni et al., 2018), or in combination with slow-release fertilizers.

Table 15 Overview of nitrification inhibitors (Trenkel, 2010; Kumar et al., 2015).

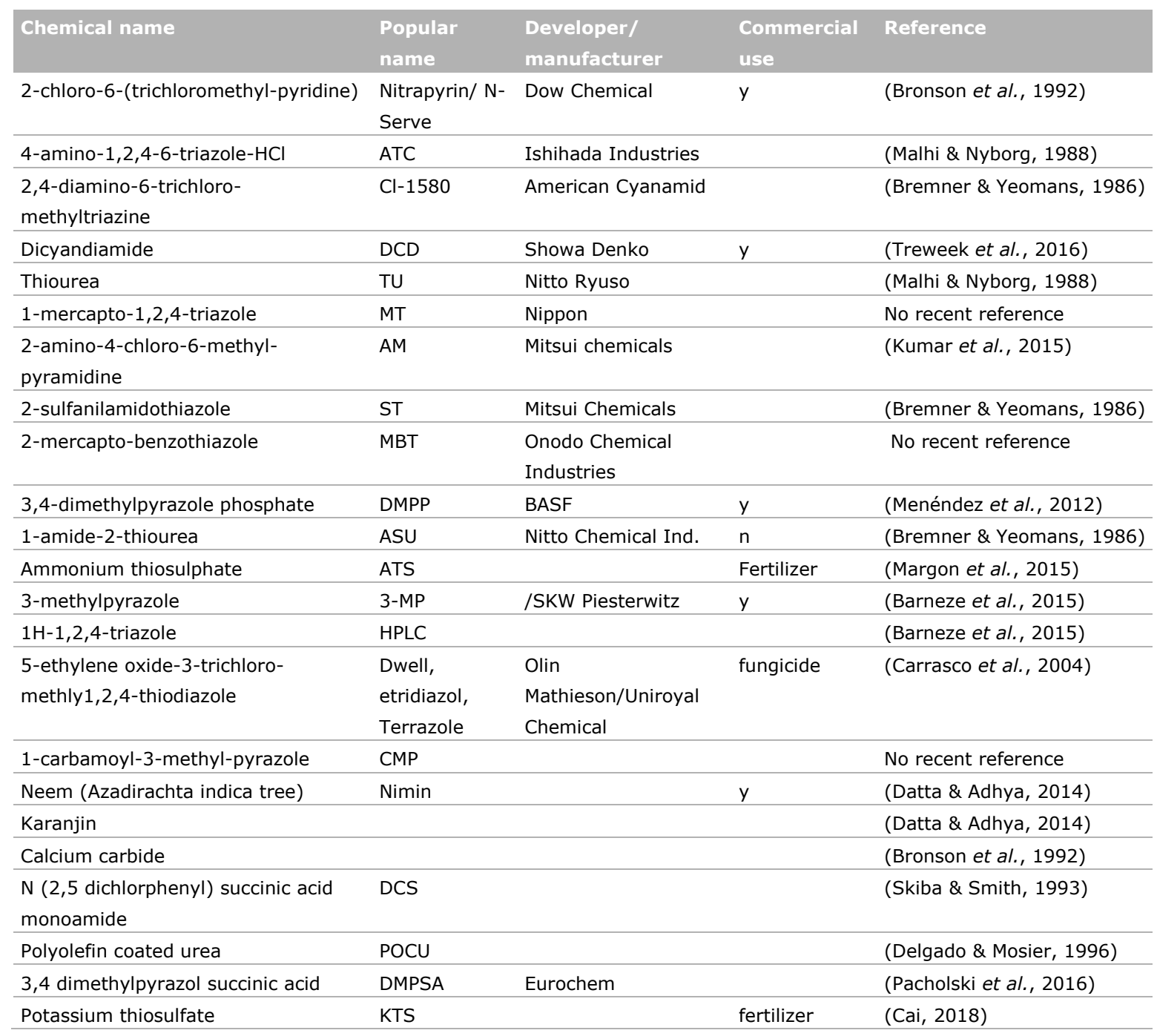

The effect of nitrification inhibitors is strongly influenced by soil and soil moisture contents. In some experiments nitrification inhibitors were completely ineffective (van der Weerden et al., 2016; Nauer et al., 2018). The reason for this is unknown. An antagonistic effect has been demonstrated between the nitrification inhibitors 3,4-dimethylpyrazole phosphate and the fungicide iprodione (Zhang, 2018). Efforts to improve knowledge of the interactions between nitrification inhibitors and chemicals for crop protection may help improve our understanding of the differing effectiveness of inhibitors. Synergism between nitrification inhibitors has been studied for ATS and DCD (Goos, 1992). This combination did not produce synergistic effects. Guanyl thiourea (GTU) and DCD in combination with urea have also been studied to assess combination effects. The inhibitory effect on nitrification was improved when urea was combined with both products (Duncan, 2017).

In addition to specific chemicals that are used as nitrification inhibitors, there are a number of substances which are used in fertilizers which also have an inhibiting effect on nitrification inhibitors. Examples of these are chloride in $\mathrm{KCl}$ or $\mathrm{NH}_{4} \mathrm{Cl}$ (Golden et al., 1981; Souri, 2010). Some nitrification inhibitors can be added as a coating around the fertilizer prill, e.g., DCD and methyl pyrimidine (Subbarao 2006). There are also a number of natural substances which act as nitrification inhibitors (Kumar et al., 2015). For example, in India an oil is extracted from the seeds of the neem plant and commercially applied (Azadirachta indica A. Juss.). The extract is used in the production of Neem oilcoated urea (NOCU) (Opoku et al., 2014). In addition, a number of studies show that black carbon or 
'Biochar' may have an inhibitory effect on $\mathrm{N}_{2} \mathrm{O}$ emission. However, a meta-study of 40 individual studies indicate that this effect is not certain (Verhoeven et al., 2017).

Some crops are able to produce nitrification inhibitors during a process called biological nitrification inhibition (BNI). This has been demonstrated in a tropical grass species, for rice (Sun et al., 2016), wheat (O'Sullivan et al., 2016), millet, peanut and sorghum (Subbarao et al., 2013; Li et al., 2018). It is possible to extract and use BNI substances from plants. During a two year field study, BNI demonstrated similar nitrification inhibiting effects as DCD (Zhang et al., 2015).

\subsubsection{Effect on $\mathrm{N}_{2} \mathrm{O}$ emission}

The effect of nitrification inhibitors on $\mathrm{N}_{2} \mathrm{O}$ emission has been reviewed during several meta-studies of literature. Akiyama et al. (2010) calculated the average effect of a number of substances on $\mathrm{N}_{2} \mathrm{O}$ emission (Table 16). These calculations show that, on average, DCD, Nitrapyrin and Ca-carbid can reduce $\mathrm{N}_{2} \mathrm{O}$ emission by approximately $50 \%$, and Thiosulphate and Neem by approximately $15-20 \%$.

Table 16 Effect of various nitrification inhibitors (Akiyama et al., 2010).

\begin{tabular}{llr} 
Nitrification inhibitor & Crop & $\begin{array}{c}\text { Decrease of } \mathrm{N}_{2} \mathrm{O} \text { emission (\%) }(\mathrm{number} \text { of } \\
\text { observations) }\end{array}$ \\
\hline DCD & Paddy rice & $36(9)$ \\
\hline Nitrapyrin & Grassland & $50(17)$ \\
\hline Ca-carbide & Grass-upland & $25(15)$ \\
\hline Thiosulphate & Diverse & $50(10)$ \\
\hline Neem & Diverse & $50(8)$ \\
\hline
\end{tabular}

Gilsanz et al. (2016) reviewed the effects of the most well-known inhibitors on $\mathrm{N}_{2} \mathrm{O}$ emissions (DCD and DMPP) in a meta-analysis (Table 17). Both nitrification inhibitors can reduce $\mathrm{N}_{2} \mathrm{O}$ emission by approximately 30 to $50 \%$ with the highest effects seen for grassland. The high effect for grassland occurs because $\mathrm{N}$ is absorbed rapidly. This means that the nitrification inhibitor needs to be effective over a relatively short time period only (up to two weeks). Conversely, it can take several weeks after application before arable crops take up $\mathrm{N}$ from the soil in significant amounts.

Following the publication of the meta-analysis by Gilsanz et al. (2016), a few additional studies have been published in which the effect of nitrification inhibitors on $\mathrm{N}_{2} \mathrm{O}$ emission has been determined (Table 18). Pacholski et al. (2016) and Guardia et al. (2018) demonstrated that the addition of the nitrification inhibitor DMPSA (3,4 dimethylpyrazol succinic acid) reduced $\mathrm{N}_{2} \mathrm{O}$ emission from CAN by $63 \%$. This result was obtained in a study in Spain with an irrigated maize crop showing that nitrification was the main source of $\mathrm{N}_{2} \mathrm{O}$ in this study (Guardia et al., 2018). Remarkably, emissions from applied nitrate were also significantly reduced in the DMPSA based treatment suggesting that this inhibitor also affects $\mathrm{N}_{2} \mathrm{O}$ production during denitrification. Torralbo et al. (2017) concluded that DMP based nitrification inhibitors stimulate the reduction of $\mathrm{N}_{2} \mathrm{O}$ to $\mathrm{N}_{2}$ by the enzyme nitrous oxide reductase during the denitrification process. Further research involving changes in microbial function is required to confirm the findings of Guardia et al. (2018) and to develop understanding of the possible influence of pyrazole $\left(\mathrm{C}_{3} \mathrm{H}_{3} \mathrm{~N}_{2} \mathrm{H}\right)$ based nitrification inhibitors on denitrifying communities and the final products of denitrification. It was concluded that the use of nitrate based fertilizers or DMPSA with ammonia based fertilizers can reduce $\mathrm{N}_{2} \mathrm{O}$ losses in irrigated agro-ecosystems.

Studies show that the effect of nitrogen inhibitors on crop varies strongly, with some studies showing large effects and others no effects at all (Duncan et al., 2017). This variation is probably due to variations in climate, soil type, crop type, and soil and crop management. The $\mathrm{N}$ use efficiency generally increases at increasing crop yield, and this may reduce the need for $\mathrm{N}$ fertilizer. This decreases emission of $\mathrm{N}_{2} \mathrm{O}$. 
Table 17 Effect of well-known nitrification inhibitors on $\mathrm{N}_{2} \mathrm{O}$ emission: DCD and DMPP (Gilsanz et al., 2016).

\begin{tabular}{llc} 
Nitrification inhibitor & Crop & Decrease Cof $N_{2}$ emission $(\%) *$ \\
DCD & Paddy rice & $34(14)$ \\
\hline & Arable & $36(8)$ \\
\hline DMPP & Grassland & $48(52)$ \\
\hline & Grassland-upland & $32(15)$ \\
\hline & Arable & $38(9)$ \\
\hline & Grassland & $46(8)$ \\
\hline
\end{tabular}

*number of observations given in brackets

Table 18 Recent studies in which effects of nitrification inhibitors have been tested.

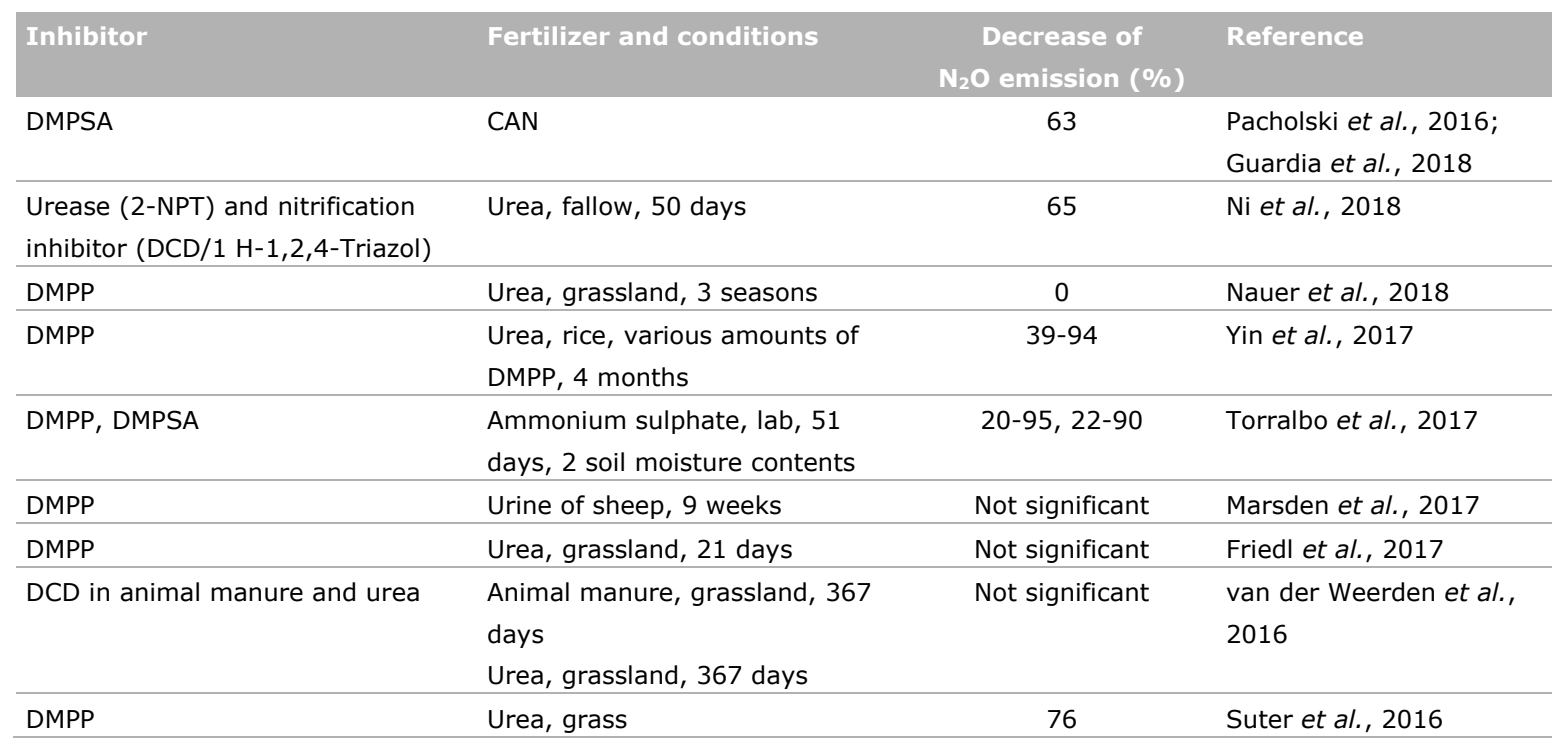

All individual studies in Table 19 are selected from Gilsanz et al. (2016) and compare fertilizers containing nitrate with other fertilizers. All studies except one show that nitrification inhibitors also reduced the $\mathrm{N}_{2} \mathrm{O}$ emission from ammonium nitrate (AN) and calcium ammonium nitrate (CAN). This is probably due to an inhibition of nitrification of the ammonium part of (C)AN. However, denitrification may also be affected by nitrification inhibitors as demonstrated by Guardia et al. (2018). The effect of rainfall on $\mathrm{N}_{2} \mathrm{O}$ emission has not been assessed in these studies. Therefore, it is not clear whether nitrification inhibitors also affect $\mathrm{N}_{2} \mathrm{O}$ emission from (C)AN applied to grassland under wet conditions. DCD was shown to be more effective in reducing $\mathrm{N}_{2} \mathrm{O}$ emission from urea than from ammonium nitrate in 4 out of 6 experiments conducted by Misselbrook et al. (2014) and in the study of McTaggart et al. (1997). In studies in which animal manure and ammonium nitrate were compared, DCD performed better for animal manure while DMPP worked better for CAN (Macadam et al., 2003). Comparisons between (C)AN and urea for arable land were only available in one study (Misselbrook et al., 2014). This study showed that, on average, nitrification inhibitors were more highly effective in reducing $\mathrm{N}_{2} \mathrm{O}$ emission from urea than from CAN.

In conclusion, the most well-known nitrification inhibitors, DCD and DMPP, are able to strongly reduce $\mathrm{N}_{2} \mathrm{O}$ emission from ammonium fertilizers. However, reductions vary widely from about 20 to $80 \%$. It has also been shown that nitrification inhibitors can reduce the $\mathrm{N}_{2} \mathrm{O}$ emission from (C)AN. This is probably due to the inhibition of nitrification of the ammonium part of (C)AN. However, denitrification may also be affected by nitrification inhibitors. 
Table 19 Effect of nitrification inhibitors on fertilizers containing nitrate and comparisons with other $N$ fertilizers. The fertilizers ammonium sulphate (AS), ammonium sulphate nitrate (ASN) ammonium nitrate $(A N)$ and calcium ammonium nitrate (CAN) are compared to cattle slurry (CS) and urea (U).

\begin{tabular}{|c|c|c|c|c|}
\hline Fertilizer & Inhibitor & Crop/soil & $\begin{array}{c}\text { Decrease in } \\
\left.\mathrm{N}_{2} \mathrm{O} \text { emission ( } \%\right)\end{array}$ & Reference \\
\hline AN & $\mathrm{DCD}$ & Grass & 42 & Macadam et al., 2003 \\
\hline CS & DMPP & & 58 & \\
\hline CAN & & & 61 & \\
\hline $\mathrm{U}$ & & & 57 & \\
\hline AS & & & 41 & \\
\hline$U$ & & & 55 & \\
\hline AN & & & 35 & \\
\hline ASN & DMPP & Grass, clay loam & 9 & Menéndez et al., 2006 \\
\hline AN & DCD & Grass, sandy loam & 33 & Misselbrook et al., 2014 \\
\hline U & & & 31 & \\
\hline AN & & Grass, clay & 44 & \\
\hline$U$ & & & 69 & \\
\hline AN & & Grass, clay loam & 39 & \\
\hline$U$ & & & 111 & \\
\hline AN & & Arable, sandy loam & 15 & \\
\hline$U$ & & & 48 & \\
\hline$U$ & DCD & Grass & 39 & (McTaggart et al., 1997) \\
\hline AN & & & -12 & \\
\hline
\end{tabular}

\subsection{Denitrification inhibitors}

A wide range of bacterial species can denitrify and several enzymes are involved in this process (See section 3.12). Therefore, inhibition of denitrification is much more difficult (less specific) than inhibition of nitrification. Moreover, if a chemical compound is not specific in its inhibition of enzymes in the denitrification process, it can inhibit the reduction of $\mathrm{N}_{2} \mathrm{O}$ to $\mathrm{N}_{2}$, which results in an increase of $\mathrm{N}_{2} \mathrm{O}$ emissions.

Although, several compounds may have inhibitory effects on denitrification, there are, unlike nitrification inhibitors, no commercial denitrification inhibitors available. Silicates have shown to inhibit denitrification (Song et al., 2017). Silicates are sometimes used as fertilizers in paddy rice fields because silicon is a (non-essential) plant nutrient. Compounds that may have some inhibitory denitrification effects include heavy metals, salts and organic compounds. However, it is not clear whether these compounds maybe used as denitrification inhibitors as their mode of action and specificity are not clear. Moreover, it is also not clear whether inhibition is complete and over what duration inhibition occurs. Toxic compounds (e.g. Toluene, azide) may have unwanted side effects on other biological processes in the soil and negatively affect soil biodiversity and/or crop production. The results summarised in the previous section show that DMP based nitrification inhibitors also decreased $\mathrm{N}_{2} \mathrm{O}$ emission from nitrate by stimulating the reduction of $\mathrm{N}_{2} \mathrm{O}$ to $\mathrm{N}_{2}$ by nitrous oxide reductase during the denitrification process. 


\subsection{Slow release fertilizers}

Slow and controlled release versions of $\mathrm{N}$ fertilizers such as S-coated urea (SCU) or polymer coated urea (PCU) may increase $\mathrm{N}$ efficiency (Subborao, 2006). A number of studies demonstrate that coating urea based fertilizers reduces $\mathrm{N}_{2} \mathrm{O}$ emission (e.g. Di Bella et al. (2017) for PCU-Agromaster and Maharjan and Venterea (2013) for PCU). However, other studies demonstrate no effect (e.g. Rose, 2017 for DMPP and PCU applied to rice and Akiyama et al. (2013) for PCU).

No references to publications testing the effect of coating of ammonium nitrate based fertilizers on $\mathrm{N}_{2} \mathrm{O}$ emission were found during a search of the literature.

\subsection{Nutrient management}

There are a number of nutrient management strategies available that aim to decrease $\mathrm{N}_{2} \mathrm{O}$ emission (Venterea et al., 2012; Oenema et al., 2014). The 4R strategy increases the nutrient use efficiency of fertilizers as well as reducing $\mathrm{N}_{2} \mathrm{O}$ emission. It encourages $\mathrm{N}$ application with the Right type of fertilizer, at the Right rate, at the Right time, and at the Right place on the basis of site, soil and crop type specific knowledge and information (http://www.ipni.net/4R).

\subsubsection{Right type}

Results from literature show that the $\mathrm{N}$ use efficiency of (calcium) ammonium nitrate is on average higher than that of regular urea and ammonium based fertilizers (Chapter 4). This is mainly due to higher ammonia losses from urea and ammonium based fertilizers compared to nitrate containing fertilizers. In addition, the application of ammonium nitrate fertilizer results in less soil acidification than ammonium and urea fertilizer application. This decreases the demand for lime and is beneficial for crop quality and the botanical composition of grassland (Chapter 4). Soil acidification may also increase $\mathrm{N}_{2} \mathrm{O}$ emission. This means that the risk of $\mathrm{N}_{2} \mathrm{O}$ emission due to acidification is greater for ammonium and urea based fertilizers than for CAN.

Emission of $\mathrm{N}_{2} \mathrm{O}$ from urea and ammonium fertilizers on arable soils is similar or higher to that of nitrate fertilizers. Emission from manure applied to arable crops on sandy soils is often higher than that of mineral $\mathrm{N}$ fertilizers. This is probably due to the application of organic matter with manure that increases denitrification capacity. Nitrate fertilizer should not be applied just after the application of manure because the fresh organic matter contained in manure can increase $\mathrm{N}_{2} \mathrm{O}$ emission from the applied nitrate.

Application of nitrate fertilizer should be avoided during wet conditions or just before expected heavy rainfall on soils with a high denitrification capacity (high amounts of easily available organic matter) such as grasslands and peat soils. Measures to decrease $\mathrm{N}_{2} \mathrm{O}$ emission during these (potentially) wet conditions are the postponement of nitrate fertilizer application or the application of an ammonium fertilizer or livestock slurry instead. Grassland can rapidly absorb N, especially in late spring, summer and early autumn resulting in a decrease of mineral $\mathrm{N}$ content during the initial days following $\mathrm{N}$ application. The risk of $\mathrm{N}_{2} \mathrm{O}$ emission after $\mathrm{N}$ application decreases if there is no or limited rainfall during this period. The application of ammonium based fertilizers with a nitrification inhibitor can further reduce $\mathrm{N}_{2} \mathrm{O}$ emission. Addition of a nitrification inhibitor may also decrease $\mathrm{N}_{2} \mathrm{O}$ emission from ammonium nitrate fertilizer, but it is doubtful that $\mathrm{N}_{2} \mathrm{O}$ emission can be strongly reduced during wet conditions with high denitrification activity.

In conclusion, Figure 23 shows a decision support tree that determines mineral $\mathrm{N}$ fertilizer types with reduced risk of $\mathrm{N}_{2} \mathrm{O}$ emission assuming that manure is applied as per common agricultural practice. (Calcium) ammonium nitrate is the mineral $\mathrm{N}$ fertilizer with, on average, the highest $\mathrm{N}$ use efficiency (Chapter 4), lowest risk of acidification (Chapter 4; reduces risk of $\mathrm{N}_{2} \mathrm{O}$ emission), and is a fertilizer that can be surface applied (reduces risk of $\mathrm{N}_{2} \mathrm{O}$ emission; Figure 20). Application of (calcium) ammonium nitrate under moderately and relatively dry conditions (where soil moisture content is at 
field capacity ${ }^{7}$ or less) results in a relatively low risk of $\mathrm{N}_{2} \mathrm{O}$ emission on both grassland and arable land. However, the application of nitrate containing mineral fertilizers such as (calcium) ammonium nitrate and urean to grasslands (all soil types) and arable land on clay and peat soils should be avoided during wet conditions. An ammonium based fertilizer (possibly with a nitrification inhibitor) or urea can be used to decrease the risk of $\mathrm{N}_{2} \mathrm{O}$ emission during wet conditions. The application of the nitrate based fertilizer should otherwise be postponed to drier periods.

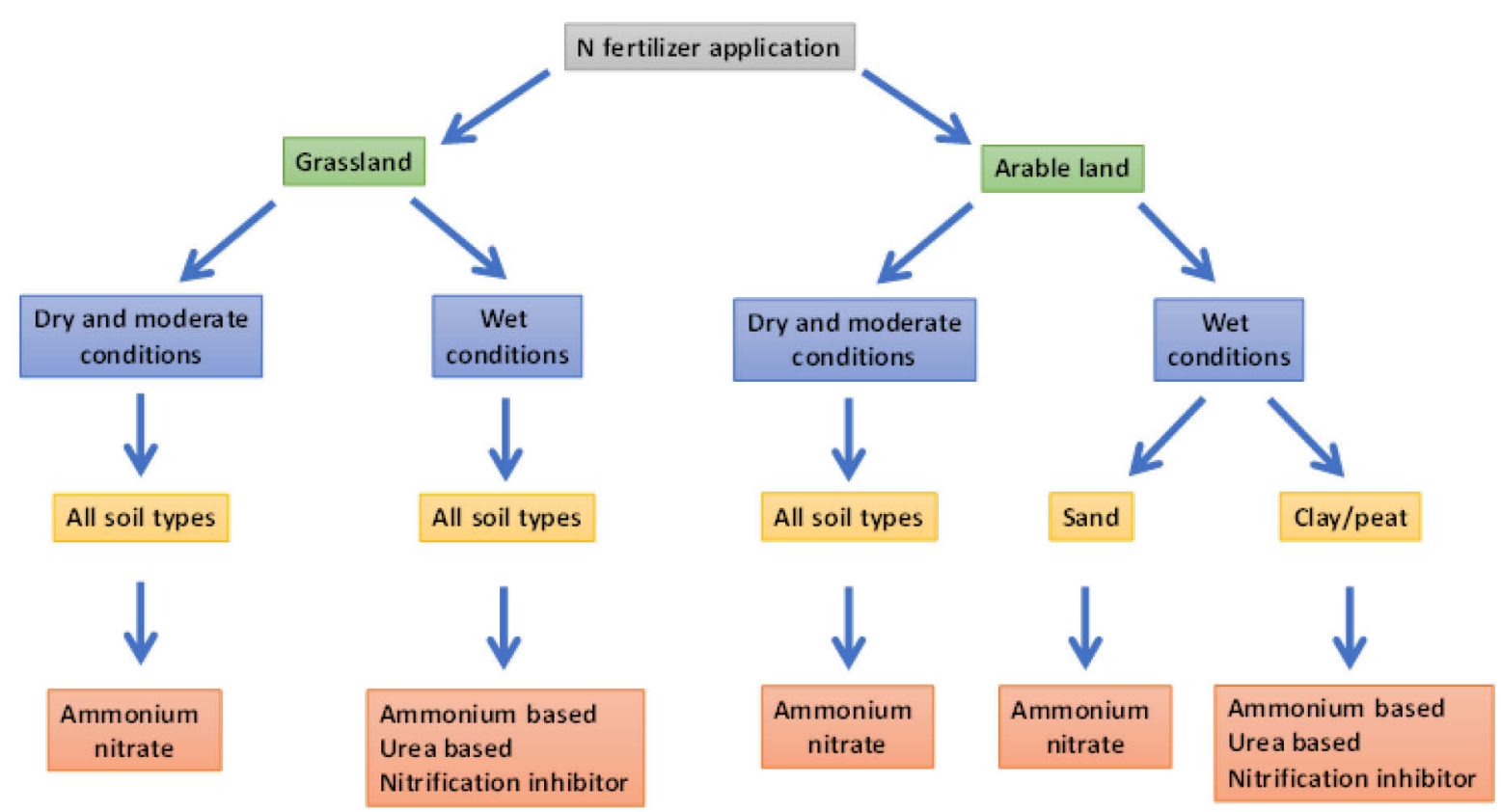

Figure 23 Decision support tree to determine mineral $N$ fertilizer types that decrease the risk of $\mathrm{N}_{2} \mathrm{O}$ emission (Velthof, unpublished).

\subsubsection{Right rate}

The application rate should be balanced with the $\mathrm{N}$ requirement of the crop as over-fertilization increases the risk of $\mathrm{N}_{2} \mathrm{O}$-emission. Van Groenigen et al. (2010) argued that agricultural management practices to reduce $\mathrm{N}_{2} \mathrm{O}$ emissions should, instead of aiming to minimize $\mathrm{N}$ application rates, focus on optimizing fertilizer- $\mathrm{N}$ use efficiency under median rates of $\mathrm{N}$ input. The amount of available $\mathrm{N}$ should be accounted for in the application of mineral $\mathrm{N}$ fertilizer if manure or other organic fertilizers are used.

Splitting $\mathrm{N}$ application up into several dressings limits the content of mineral $\mathrm{N}$ in the soil and minimises the period of elevated mineral $\mathrm{N}$ content. This decreases the risk of $\mathrm{N}_{2} \mathrm{O}$ emission. Splitting the recommended $\mathrm{N}$ rate into two smaller dressings may decrease $\mathrm{N}_{2} \mathrm{O}$ emission during wet periods on grasslands.

\subsubsection{Right time}

The risk of $\mathrm{N}_{2} \mathrm{O}$ emission is highest when the mineral $\mathrm{N}$ content of the soil is elevated. Therefore, shortening the period of elevated soil mineral $\mathrm{N}$ content after fertilizer or manure application decreases the risk of $\mathrm{N}_{2} \mathrm{O}$ emission. The $\mathrm{N}$ should be applied during or just before the crop growing period.

The risk of $\mathrm{N}_{2} \mathrm{O}$ emission increases when the moisture content of the soil increases for ammonium, urea, and nitrate based fertilizers. Application of a nitrate fertilizer to soils with a high denitrification

\footnotetext{
7 Soil moisture content after excess water has drained away in a freely drained soil (within 1 to 2 days after the soil has been saturated).
} 
capacity (grasslands and peat soils) should be avoided during wet conditions due to the high risk of $\mathrm{N}_{2} \mathrm{O}$ emission. Soils with a high denitrification capacity are those that contain easily available organic matter. An ammonium based fertilizer (possibly with a nitrification inhibitor) can be used to decrease the risk of $\mathrm{N}_{2} \mathrm{O}$ emission during wet conditions. The application of nitrate based fertilizer should otherwise be postponed to drier periods.

Application of manures, urea and urean and application of ammonium fertilizer to calcareous soils lead to a high risk of ammonia emission which decreases the $\mathrm{N}$ use efficiency of these fertilizers. These fertilizers should be applied during rainy conditions to decrease ammonia emission. High ammonia losses decrease the $\mathrm{N}$ use efficiency and, depending on the $\mathrm{N}$ application rate, increase the need for additional $\mathrm{N}$ fertilizers which increases the risk of nitrate leaching. Ammonia is also a source of indirect $\mathrm{N}_{2} \mathrm{O}$ emission suggesting that ammonia emission reduction will also reduce $\mathrm{N}_{2} \mathrm{O}$ emission.

\subsubsection{Right Place}

Surface application of fertilizers and manures decreases $\mathrm{N}_{2} \mathrm{O}$ emission relative to incorporation or injection. Surface application will increase the risk of ammonia emission but this risk is much smaller for CAN than for urea, urean, ammonium fertilizers and livestock manure. Ammonia is also a source of indirect $\mathrm{N}_{2} \mathrm{O}$ emission suggesting that ammonia emission reduction will also reduce $\mathrm{N}_{2} \mathrm{O}$ emission. 


\section{References}

Abbasi, M.K. and Adams, W.A., 2000. Gaseous N emissions during simultaneous nitrificationdenitrification associated with mineral $\mathrm{N}$ fertilization to a grassland soil under field conditions. Soil Biol. Biochem. 32: 1251-1259

Akiyama, H., Yan, X. \& Yagi, K., 2010. Evaluation of effectiveness of enhanced-efficiency fertilisers as mitigation options for N2O and NO emissions from agricultural soils: Meta-analysis. Global Change Biology, 16, 1837-1846.

Akiyama, H., Morimoto, S., Hayatsu, M., Hayakawa, A., Sudo, S. \& Yagi, K., 2013. Nitrification, ammonia-oxidizing communities, and $\mathrm{N} 2 \mathrm{O}$ and $\mathrm{CH} 4$ fluxes in an imperfectly drained agricultural field fertilized with coated urea with and without dicyandiamide. Biology and fertility of soils, 49, 213-223.

Ambus, P., Jensen, J.M., Prieme, A., Pilegaard, K. and Kjoller, A., 2001. Assessment of CH4 and N2O fluxes in a Danish beech (Fagus sylvatica) forest and an adjacent $\mathrm{N}$-fertilised barley (Hordeum vulgare) field: effects of sewage sludge amendments. Nutr. Cycl. Agroecosys., 60, 15-21.

Anger, M., Hoffman, C. and Kühbauch, W., 2003. Nitrous oxide emissions from artificial urine patches applied to different $\mathrm{N}$-fertilized swards and estimated annual N2O emissions for differently fertilized pastures in an upland location in Germany. Soil Use and Management 19, 104-111.

Arah, J.R.M., Smith, K.A., Crighton, I.J. and Li, H.S., 1991. Nitrous oxide production and denitrification in Scottish arable soils. Soil Sci. 42, 351-367.

Assink, F.B.T., Steenbergen, T. van, Brouwer, F., Velthof, G.L., 2005. De bodemgesteldheid van de referentiepercelen. Resultaten van veld- en laboratoriumonderzoek. Koeien en Kansen rapport 31/Alterra Rapport 1228.

Ball, B.C., Horgan, G.W. and Parker, J.P., 2000. Short-range spatial variation of nitrous oxide fluxes in relation to compaction and straw residues. European Journal of Soil Science 51, 607-616.

Barneze, A., Minet, E., Cerri, C. \& Misselbrook, T., 2015. The effect of nitrification inhibitors on nitrous oxide emissions from cattle urine depositions to grassland under summer conditions in the UK. Chemosphere, 119, 122-129.

Bell, M., N. Hinton, J. Cloy, C. Topp, R. Rees, L. Cardenas, T. Scott, C. Webster, R. Ashton, A. Whitmore, 2015. Nitrous oxide emissions from fertilised UK arable soils fluxes, emission factors and mitigation. Agriculture, Ecosystems and Environment 212, 134-147.

Bhogal, A., Dampney, P. and Goulding, K., 2003. Evaluation of Urea-Based Nitrogen Fertilisers. Report for Defra projects NT2601 and NT2602.

Bolan, N.S., Adriano, D.C. and Curtin, D., 2003. Soil acidification and liming interactions with nutrient and heavy metal transformation and bioavailability. Advances in Agronomy 78, 215-272.

Bouwman, A.F., 1996. Direct emission of nitrous oxide from agricultural soils. Nutrient Cycling in Agroecosystems 46 (1), 53-70.

Bremner, J. \& Yeomans, J., 1986. Effects of nitrification inhibitors on denitrification of nitrate in soil. Biology and fertility of soils, 2, 173-179.

Bronson, K., Mosier, A. \& Bishnoi, S., 1992. Nitrous oxide emissions in irrigated corn as affected by nitrification inhibitors. Soil Science Society of America Journal, 56, 161-165.

Burford, J.R., Dowdell, R.J. and Crees, R., 1981. Emission of nitrous oxide to the atmosphere from direct drilled and ploughed clay soils. J. Sci. Food Agric. 32, 219-223.

Bussink, D.W. \& Oenema, O., 1996. Differences in rainfall and temperature define the use of different types of nitrogen fertilizer on managed grassland in UK, NL and Eire. Netherlands Journal of Agricultural Science 44 1996, 317 - 338.

Butterbach-Bahl, K., Baggs, E.M., Dannenmann, M., Kiese, R., Zechmeister-Boltenstern, S., 2013 Nitrous oxide emissions from soils: how well do we understand the processes and their controls? Philosophical Transactions of the Royal Society B: Biological Sciences 368.

Cai, Z., Gao, S., Xu, M. \& Hanson, B.D., 2018. Evaluation of potassium thiosulfate as a nitrification inhibitor to reduce nitrous oxide emissions. Science of the Total Environment, 618, 243-249. 
Carrasco, D., Fernández-Valiente, E., Ariosa, Y. \& Quesada, A., 2004. Measurement of coupled nitrification-denitrification in paddy fields affected by Terrazole, a nitrification inhibitor. Biology and fertility of soils, 39, 186-192.

CBGV, 2017. Bemestingsadvies grasland en voedergewassen. http://edepot.wur.nl/413891

Chadwick, D.R., Pain, B.F. and Brookman, S.K.E., 2000. Nitrous oxide and methane emissions following application of animal manures to grassland. J. Environ. Qual. 29, 277-287.

Chalk, P.M. and Smith, C.J., 1983. Chemodenitrification. In: Freney, J.R., Simpson, J.R. (Eds.), Gaseous loss of nitrogen from plant-soil systems. Developments in Plant and Soils Sciences 9, 65-89.

Chien, S.H., Prochnow, L.I. \& Cantarella, H., 2009. Chapter 8 Recent Developments of Fertilizer Production and Use to Improve Nutrient Efficiency and Minimize Environmental Impacts. In: Advances in Agronomy. pp. 267-322.

Christensen, S., 1983 Nitrous oxide emission from a soil under permanent grass: seasonal and diurnal fluctuations as influenced by manuring and fertilization. Soil Biol. Biochem. 15, 531-536.

Christensen, S. and Christensen, B.T., 1991. Organic matter available for denitrification in different soil fractions: effect of freeze/ thaw cycles and straw disposal. Journal of Soil Science. 42: 637-647.

Clayton, H., Arah, J.R.M. and Smith, K.A., 1994. Measurement of nitrous oxide emissions from fertilised grassland using closed chambers. J. Geophys. Res. 99, 16599-16607.

Clayton, H., McTaggart, I.P., Parker, J., Swan, L. and Smith, K.A., 1997. Nitrous oxide emissions from fertilized grassland: a 2-year study of the effects of $\mathrm{N}$ fertilizer form and environmental conditions. Biol. Fertil. Soils 25, 252-260.

Clemens, J., Vandré, R., Kaupenjohann, M. and Goldbach, H., 1997. Ammonia and nitrous oxide emissions after land spreading of manure as influenced by application technique and dry matterreduction. II. Short term nitrous oxide emissions. Z. Pflanzenernähr. Bodenk. 160, 491-496.

Coenen, P.W.H.G., C.W.M. van der Maas, P.J. Zijlema, E.J.M.M. Arets, K. Baas, A.C.W.M. van den Berghe, E.P. van Huis, G. Geilenkirchen, M. Hoogsteen, J. Spijker, R. te Molder, R. Dröge, J.A. Montfoort, C.J. Peek, J. Vonk, S. Oude Voshaar, S. Dellaert, 2017 Greenhouse Gas Emissions in the Netherlands 1990-2015 National Inventory Report 2017. RIVM Report 2017-0033

http://www.pbl.nl/sites/default/files/cms/publicaties/PBL2017_Greenhouse-gas-emissions-in-theNetherlands-1990-2015-national-inventory-report-2017.pdf

Colbourn, P., Iqbal, M.M. and Harper, I.W., 1984. Denitrification losses from 15N labelled calcium fertilizer in a clay soil in the field. J. Soil Sci. 35, 539-547.

Conrad, R., Seiler, W. and Bunse, G., 1983. Factors influencing the loss of fertilizer nitrogen in the atmosphere as N2O. J. Geophys. Res. 88, 6709-6718.

Coyotzi, S., Doxey, A.C., Clark, I.D., Lapen, D.R., Van Cappellen, P. \& Neufeld, J.D., 2017. Agricultural soil denitrifiers possess extensive nitrite reductase gene diversity. Environmental Microbiology, 19, 1189-1208.

Dampney, P., C. Dyer, G. Goodlass and B. Chambers, 2006. WP1a Crop Responses. Component report for Defra Project NT2605 (CSA 6579)

Datta, A. \& Adhya, T.K., 2014. Effects of organic nitrification inhibitors on methane and nitrous oxide emission from tropical rice paddy. Atmospheric Environment, 92, 533-545.

Delgado, J. \& Mosier, A., 1996. Mitigation alternatives to decrease nitrous oxides emissions and ureanitrogen loss and their effect on methane flux. Journal of Environmental Quality, 25, 1105-1111.

Delwiche, C.C., 1981. The nitrogen cycle and nitrous oxide. In: Delwiche, C.C. (Ed.). Denitrification, Nitrification and Atmospheric Nitrous Oxide. John Wiley \& Sons, New York, pp. 1-15.

Den Boer, D.J., G. Holshof, D.W. Bussink and J.C. van Middelkoop, 2011. Type en toedieningsvorm van N-kunstmest; Effecten op gewas- en eiwitproductie en -kwaliteit. Rapport 1364.N.09

Di Bella, L.P., Armour, J., Moody, P., Royle, M., Ibanez, M. \& Le Bris, M., 2017. The assessment of enhanced efficiency Fertilisers (EEFS) in a glasshouse experiment to investigate nitrogen loss pathways in sugarcane. In: 39th Conference of the Australian Society of Sugar Cane Technologists, ASSCT 2017. pp. 263-273.

Dobbie, K.E. and Smith, K.A., 2003. Nitrous oxide emission factors for agricultural soil in Great Brain: the impact of soil water-filled pore space and other controlling variables. Glob. Change Biol. 9, 204-218.

Dobbie, K.E., McTaggart, I.P. and Smith, K.A., 1999. Nitrous oxide emissions from intensive agricultural systems: variations between crops and seasons, key driving variables, and mean emission factors. Journal of Geophysical Research 104, 26891-26899. 
Duncan, E.G., O'Sullivan, C.A., Roper, M.M., Peoples, M.B., Treble, K. \& Whisson, K., 2017. Crop and microbial responses to the nitrification inhibitor 3,4-dimethylpyrazole phosphate (DMPP) in Mediterranean wheat-cropping systems. Soil Research, 55, 553-566.

Eggington, G.M. and Smith, K.A., 1986. Nitrous oxide emission from a grassland soil fertilized with manure and calcium nitrate. J. Soil Sci. 37, 59-67.

Ellis, S., Yamulki, S., Dixon, E., Harrison, R. and Jarvis, S.C., 1998. Denitrification and N2O emissions from a UK pasture soil following the early spring application of cattle manure and mineral fertilizer. Plant Soil 202, 15-25.

Firestone, M.K., 1982. Biological denitrification. In: Stevenson, F.J. (Ed.), Nitrogen in agricultural soils. Agronomy 22, 289-326.

Firestone, M.K., Davidson, E.A., 1989. Microbiological basis of NO and N2O production and consumption in soil, In: Andreae, M.O., Schimel, D.S. (Eds.), Exchange of trace gases between terrestrial ecosystems and the atmosphere. John Wiley \& Sons, New York, pp. 7-21.

Forrestal, P.J., M.A. Harty, R. Carolan, C.J. Watson, G.J. Lanigan, D.P. Wall, D. Hennessy, K.G. Richards, 2017 Can the agronomic performance of urea equal calcium ammonium nitrate across nitrogen rates in temperate grassland? Soil Use and Management 33, 243-251.

Friedl, J., Scheer, C., Rowlings, D.W., Mumford, M.T. \& Grace, P.R., 2017. The nitrification inhibitor DMPP (3,4-dimethylpyrazole phosphate) reduces N2 emissions from intensively managed pastures in subtropical Australia. Soil Biology and Biochemistry, 108, 55-64.

Geel, van W., B. Kroonen-Backbier, D. van der Schans and J.T. Malda, 2011 Nieuwe bijmestsystemen en -strategieën voor aardappel op zand- en lössgrond. Deel 1a: Deskstudie. PPO-report 439, PPO Lelystad.

Gilhespy, S.L., S. Anthony, L. Cardenas, D. Chadwick, A. del Prado, C. Li, T. Misselbrook, R.M. Rees, W. Salas, A. Sanz-Cobena, P. Smith, E.L. Tilston, C.F.E. Topp, S. Vetter, J.B. Yeluripati, 2014. First 20 years of DNDC (DeNitrification DeComposition): Model evolution, Ecological Modelling 292, 51-62.

Gilsanz, C., Báez, D., Misselbrook, T.H., Dhanoa, M.S. \& Cárdenas, L.M., 2016. Development of emission factors and efficiency of two nitrification inhibitors, DCD and DMPP. Agriculture, Ecosystems \& Environment, 216, 1-8.

Glatzel, S. and Stahr, K., 2001. Methane and nitrous oxide exchange in differently fertilized grassland in southern Germany. Plant and Soil 231, 21-35.

Golden, D., Sivasubramaniam, S., Sandanam, S. \& Wijedasa, M., 1981. Inhibitory effects of commercial potassium chloride on the nitrification rates of added ammonium sulphate in an acid red yellow podzolic soil. Plant and Soil, 59, 147-151.

Goossens, A., De Visscher, A., Boeckx, P. and Van Cleemput, O., 2001. Two-year field study on the emission of $\mathrm{N} 2 \mathrm{O}$ from coarse and middle-textured Belgian soils with different land use. Nutr. Cycl. Agroecosyst. 60, 23-34.

Granli, T. and Bøckman, O.C., 1994. Nitrous oxide from agriculture. Norwegian Journal of Agricultural Sciences Supplement 12, 7-128.

Guardia, G., A. Vallejo, L.M. Cardenas, E.R. Dixon, S. García-Marco, 2018. Fate of 15N-labelled ammonium nitrate with or without the new nitrification inhibitor DMPSA in an irrigated maize crop. Soil Biology and Biochemistry 116, 193-202.

Harmsen, K., Loman, H. and Neeteson, J.J., 1990. A derivation of the Pierre-Sluijsmans equation used in the Netherlands to estimate the acidifying effect of fertilisers applied to agricultural soil. Fertilizer Research 26, 319-325.

Heil, J., H. Vereecken, N. Brüggemann, 2016. A review of chemical reactions of nitrification intermediates and their role in nitrogen cycling and nitrogen trace gas formation in soil. European Journal of Soil Science, 67, 23-39.

Hénault, C., Devis, X., Lucas, J.L. and Germon, J.C., 1998. Influence on different agricultural practices (type of crop, form of $\mathrm{N}$-fertilizer) on soil nitrous oxide emissions. Biol. Fertil. Soils 27, 299-306.

Huijsmans, J.F.M., Schroder, J., Mosquera, J., Vermeulen, G.D., Berge, H.F.M. Ten, Neeteson, J.J., 2015. Ammonia emissions from cattle slurries applied to grassland: Should application techniques be reconsidered? Soil Use and Management 32, 109 - 116.

IPCC, 2013. Climate Change 2013: The Physical Science Basis. Contribution of Working Group I to the Fifth Assessment Report of the Intergovernmental Panel on Climate Change [Stocker, T.F., D. Qin, G.-K. Plattner, M. Tignor, S.K. Allen, J. Boschung, A. Nauels, Y. Xia, V. Bex and P.M. Midgley (eds.)]. Cambridge University Press, Cambridge, United Kingdom and New York, NY, USA, 1535 pp. 
Jambert, C., Delmas, R., Serca, D., Thouron, L., Labroue, L. and Delprat, L., 1997. N2O and CH4 emissions from fertilized agricultural soils in southwest France. Nutrient Cycling in Agroecosystems 48, $105-114$.

Jones, S.K., Rees, R.M., Skiba, U.M., Ball, B.C., 2005. Greenhouse gas emissions from a managed grassland. Global and Planetary Change 47, 201-211.

Jones, S.K., Rees, R.M., Skiba, U.M., Ball, B.C., 2007. Influence of organic and mineral N fertiliser on N2O fluxes from a temperate grassland. Agriculture, Ecosystems \& Environment 121, 74-83.

Jørgensen, R.N., Jørgensen, B.J., Nielsen, N.E., Maag, M. and Lind, A.M., 1997. N2O emission from energy crop fields of Miscanthus Giganteous and winter rye. Atmospheric Environment 31(18), 2899-2904.

Kaiser, E.A., Kohrs, K., Kücke, E., Schnug, E., Munch, J.C. and Heinemeyer, O., 1996. Nitrous oxide from cultivated soils: influence of different $\mathrm{N}$-fertilizer types. In Transactions of the 9th Nitrogen Workshop, eds. B. Diekkrüger, O. Heinemeyer and R. Nieder, pp. 149-152. Braunschweig, September. Technische Universität Braunschweig.

Kaiser, E.A., Kohrs, K., Kucke, M., Schnug, E., Heinemeyer, O. and Munch, J.C., 1998. Nitrous oxide release from arable soil: importance of $\mathrm{N}$-fertilization, crops and temporal variation. Soil Biology and Biochemistry. 30: 1553-1563.

Kaiser, E.A., Kohrs, M., Kücke, M., Schnug, E., Munch, J.C., and Heinemeyer, O., 1998. Nitrous oxide release from arable soil: importance of different perennial forage crops. Biol. Fert. Soils 28, 36-43.

Kamp, T., Steindl, H., Hantschel, R.E., Beese, F. and Munch, J.C., 1998. Nitrous oxide emissions from a fallow and wheat field as affected by increased soil temperatures. Biol. Fertil. Soils 27, 307-314.

Knowles, R., 1982. Denitrification. Microbiological Reviews 46, 43-70.

Kumar, R., Parmar, B.S., Walia, S. \& Saha, S., 2015. Nitrification inhibitors: classes and its use in nitrification management. In: Nutrient Use Efficiency: from Basics to Advances. Springer, pp. 103122.

Lebender, U., Senbayram, M., Lammel, J., 2014 Effect of mineral nitrogen fertilizer forms on $\mathrm{N} 2 \mathrm{O}$ emissions from arable soils in winter wheat production. Journal of Plant Nutrition and Soil Science 177, 722-732.

Leick, B., Engels, C., 2001. Effects of various nitrogen fertilisers on nitrous oxide emissions from arable soils. In: Horst, W.J. (Ed.), Plant Nutrition: Food Security and Sustainability of AgroEcosystems Through Basic and Applied Research. Developments in Plant and Soil Sciences, vol. 92. Kluwer Academic Publishers, Dordrecht, The Netherlands, pp. 882-883.

Li, Y., Chapman, S.J., Nicol, G.W. \& Yao, H., 2018. Nitrification and nitrifiers in acidic soils. Soil Biology and Biochemistry, 116, 290-301.

Linzmeier, W., Gutser, R. \& Schmidhalter, U., 2001. Nitrous oxide emission from soil and from a nitrogen-15-labelled fertilizer with the new nitrification inhibitor 3, 4-dimethylpyrazole phosphate (DMPP). Biology and fertility of soils, 34, 103-108.

Liu, B., Frostegård, A. \& Bakken, L.R., 2014. Impaired reduction of N2O to N2 in acid soils is due to a posttranscriptional interference with the expression of nosZ. MBio, 5, e01383-01314.

Macadam, X.M.B., del Prado, A., Merino, P., Estavillo, J.M., Pinto, M. \& González-Murua, C., 2003. Dicyandiamide and 3, 4-dimethyl pyrazole phosphate decrease N2O emissions from grassland but dicyandiamide produces deleterious effects in clover. Journal of plant physiology, 160, 1517-1523.

Maharjan, B. \& Venterea, R.T., 2013. Nitrite intensity explains N management effects on N2O emissions in maize. Soil Biology and Biochemistry, 66, 229-238.

Malhi, S. \& Nyborg, M., 1988. Control of nitrification of fertilizer nitrogen: effect of inhibitors, banding and nesting. Plant and Soil, 107, 245-250.

Margon, A., Parente, G., Piantanida, M., Cantone, P. \& Leita, L., 2015. Novel investigation on ammonium thiosulphate (ATS) as an inhibitor of soil urease and nitrification. Agricultural Sciences, $6,1502$.

Marsden, K.A., Jones, D.L. \& Chadwick, D.R., 2017. DMPP is ineffective at mitigating N2O emissions from sheep urine patches in a UK grassland under summer conditions. Agriculture, Ecosystems and Environment, 246, 1-11.

Matsuoka, M., Kumar, A., Muddassar, M., Matsuyama, A., Yoshida, M. \& Zhang, K.Y.J., 2017. Discovery of Fungal Denitrification Inhibitors by Targeting Copper Nitrite Reductase from Fusarium oxysporum. Journal of Chemical Information and Modeling, 57, 203-213. 
McTaggart, I., Clayton, H., Parker, J., Swan, L. \& Smith, K., 1997. Nitrous oxide emissions from grassland and spring barley, following $\mathrm{N}$ fertiliser application with and without nitrification inhibitors. Biology and fertility of soils, 25, 261-268.

McTaggart, I.P., Clayton, H., Parker, J., Swan, L. and Smith, K.A., 1997. Nitrous oxide emissions from grassland and spring barley, following $\mathrm{N}$ fertilizer application with and without nitrification inhibitors. Biol. Fertil. Soils 25, 261-268.

Menéndez, S., Barrena, I., Setien, I., González-Murua, C. \& Estavillo, J.M., 2012. Efficiency of nitrification inhibitor DMPP to reduce nitrous oxide emissions under different temperature and moisture conditions. Soil Biology and Biochemistry, 53, 82-89.

Menéndez, S., Merino, P., Pinto, M., González-Murua, C. \& Estavillo, J., 2006. 3, 4-Dimethylpyrazol phosphate effect on nitrous oxide, nitric oxide, ammonia, and carbon dioxide emissions from grasslands. Journal of Environmental Quality, 35, 973-981.

Merino, P., Estavillo, J., Graciolli, L., Pinto, M., Lacuesta, M., Munoz-Rueda, A. \& Gonzalez-Murua, C., 2002. Mitigation of $\mathrm{N} 2 \mathrm{O}$ emissions from grassland by nitrification inhibitor and Actilith F2 applied with fertilizer and cattle slurry. Soil use and management, 18, 135-141.

Misselbrook, T., Cardenas, L., Camp, V., Thorman, R., Williams, J., Rollett, A. \& Chambers, B., 2014. An assessment of nitrification inhibitors to reduce nitrous oxide emissions from UK agriculture. Environmental Research Letters, 9, 115006.

Misselbrook, T.H., Chadwick, D.R., Pain, B.F. and Headon, D.M., 1998. Dietary manipulation as a means of decreasing $\mathrm{N}$ losses and methane emissions and improving herbage $\mathrm{N}$ uptake following application of pig manure to grassland. J. Agric. Sci. 130, 183-191.

Mogge, B., Kaiser, E.A. and Munch, J.C., 1999. Nitrous oxide emissions and denitrification N-losses from agricultural soils in the Bornhöved Lake region (Northern Germany): influence of organic fertilizers and land-use. Soil Biol. Biochem. 31, 1245-1252.

Nauer, P.A., Fest, B.J., Visser, L. \& Arndt, S.K., 2018. On-farm trial on the effectiveness of the nitrification inhibitor DMPP indicates no benefits under commercial Australian farming practices. Agriculture, Ecosystems and Environment, 253, 82-89.

$\mathrm{Ni}$, K., Kage, H. \& Pacholski, A., 2018. Effects of novel nitrification and urease inhibitors (DCD/TZ and 2-NPT) on N2O emissions from surface applied urea: An incubation study. Atmospheric Environment, 175, 75-82.

NMI, 2000. Handboek Mestoffen, Elsevier

O'Sullivan, C.A., Fillery, I.R., Roper, M.M. \& Richards, R.A., 2016. Identification of several wheat landraces with biological nitrification inhibition capacity. Plant and Soil, 404, 61-74.

Olivier, J.G.J. et al., 2017. Trends in global CO2 and total greenhouse gas emissions: 2017 report. PBL Netherlands Environmental Assessment Agency, The Hague. http://www.pbl.nl/sites/default/files/cms/publicaties/pbl-2017-trends-in-global-co2-and-totalgreenhouse-gas-emissons-2017-report_2674.pdf

Opoku, A., Chaves, B. \& De Neve, S., 2014. Neem seed oil: a potent nitrification inhibitor to control nitrate leaching after incorporation of crop residues. Biological Agriculture \& Horticulture, 30, 145-152.

Pacholski, A., Berger, N., Bustamante, I., Ruser, R., Guardia, G. \& Mannheim, T., 2016. Effects of the novel nitrification inhibitor DMPSA on yield, mineral $\mathrm{N}$ dynamics and $\mathrm{N} 2 \mathrm{O}$ emissions. In: Proceedings of the 2016 International Nitrogen Initiative Conference," Solutions to improve nitrogen use efficiency for the world. pp. 4-8.

Pathak, H., Nedwell, D.B., 2001. Nitrous oxide emission from soil with different fertilizers, water levels and nitrification inhibitors. Water, Air, \& Soil Pollution 129, 217-228.

Petersen, S.O., 1999. Nitrous oxide emissions from manure and inorganic fertilizers applied to spring barley. J. Environ. Qual. 28, 1610-1618.

Pilegaard, K., 2013. Processes regulating nitric oxide emissions from soils. Phil Trans R Soc B 368: 20130126.

Postma, R., P. Dekker, L. van Schöll, J. Paauw, K. Wijnholds, H. Verstegen, 2009. Toetsing van meststoffen en bemestingssystemen in de aardappelteelt; veldproeven 2006-2008. NMI Rapport 1161 , Nutriënten Management Instituut NMI, Wageningen.

Ravishankara, A.R., Daniel, J.S., Portmann, R.W., 2009. Nitrous oxide (N2O): the dominant ozonedepleting substance emitted in the 21st century. Science 326(5949): 123-5.

Reay, D.S., Davidson, E.A., Smith, K.A., Smith, P., Melillo, J.M., Dentener, F. \& Crutzen, P.J., 2012. Global agriculture and nitrous oxide emissions. Nature climate change, 2, 410. 
Roche, L., P.J. Forrestal, G.J. Lanigan, K.G. Richards, L.J. Shaw, D.P. Wall, 2016. Impact of fertiliser nitrogen formulation, and $\mathrm{N}$ stabilisers on nitrous oxide emissions in spring barley. Agriculture, Ecosystems \& Environment 233, p. 229-237.

Rohde, L., Pell, M. and Yamulki, S., 2006. Nitrous oxide, methane and ammonia emissions following manure spreading on grassland. Soil Use and Management 22, 229-237.

Rose, T.J., Morris, S.G., Quin, P., Kearney, L.J., Kimber, S. \& Van Zwieten, L., 2017. The nitrification inhibitor DMPP applied to subtropical rice has an inconsistent effect on nitrous oxide emissions. Soil Research, 55, 547-552.

Rose, T.J., R.H. Wood, M.T. Rose, L. Van Zwieten, 2018. A re-evaluation of the agronomic effectiveness of the nitrification inhibitors DCD and DMPP and the urease inhibitor NBPT. Agriculture, Ecosystems and Environment 252, 69-73.

Russenes, A.L., A. Korsaeth, L.R. Bakken, P. Dörsch, 2016. Spatial variation in soil pH controls offseason N2O emission in an agricultural soil. Soil Biology \& Biochemistry 99, $36-46$.

Ryden, J.C., 1981. N2O exchange between a grassland soil and the atmosphere. Nature 292, 235-237.

Schils, R.L.M., van Groenigen, J.W., Velthof, G.L. and P.J. Kuikman., P.J., 2008. Nitrous oxide emissions from multiple combined applications of fertiliser and cattle manure to grassland. Plant and Soil 310, 89-101.

Schils, R.L.M., Van Groenigen, J.W., Velthof, G.L. and Kuikman, P.J., 2010. Fertilising practices to reduce nitrous oxide emissions from managed grasslands. Grassland Science in Europe, Vol. 15, pp 81-83.

Schröder, J.J., J.C. van Middelkoop, W. van Dijk and G.L. Velthof, 2008. Quick scan Stikstofwerking van dierlijke mest; actualisering van kennis en de mogelijke gevolgen van aangepaste forfaits. Wageningen, Wettelijke Onderzoekstaken Natuur \& Milieu, WOt-rapport 85. 55 p.

Seiler, W. and Conrad, R., 1981. Field measurements of natural and fertilizer-induced N2O release rates from soils. J. Air Pollut. Control Assoc. 31, 767-772.

Shaaban, M., Wu, Y., Khalid, M.S., Peng, Q.-a., Xu, X., Wu, L., Younas, A., Bashir, S., Mo, Y., Lin, S., Zafar-ul-Hye, M., Abid, M. \& Hu, R., 2018. Reduction in soil N2O emissions by pH manipulation and enhanced nosZ gene transcription under different water regimes. Environmental Pollution, 235, 625-631.

Skiba, U. \& Smith, K., 1993. Nitrification and denitrification as sources of nitric oxide and nitrous oxide in a sandy loam soil. Soil Biology and Biochemistry, 25, 1527-1536.

Skiba, U.M., Hargreaves, K.J., Fowler, D. and Smith, K.A., 1992. Fluxes of nitric and nitrous oxides from agricultural soils in a cool temperate climate. Atmos. Environ. 26A, 2477-2488.

Skiba, U.M., Sheppard, L.J., MacDonald, J. and Fowler, D., 1998. Some key environmental variables controlling nitrous oxide emissions from agricultural and semi-natural soils in Scotland. Atmospheric Environment 32, 3311-3320.

Slangen, J. \& Kerkhoff, P., 1984. Nitrification inhibitors in agriculture and horticulture: a literature review. Fertilizer Research, 5, 1-76.

Slemr, F., Conrad, R. and Seiler, W., 1984. Nitrous oxide emissions from fertilized and unfertilized soils in a subtropical region (Andalusia, Spain). J. Atmos. Chem. 1, 159-169.

Smith, K.A., McTaggart, I.P., Dobbie, K.E. and Conen, F., 1998b. Emissions of N2O from Scottish agricultural soils, as a function of fertilizer N. Nutrient Cycling in Agroecosystems 52, 123-130.

Smith, K.A., Thomson, P.E., Clayton, H., McTaggart, I.P. and Conen, F., 1998a. Effects of temperature, water content and nitrogen fertilization on emissions of nitrous oxide by soils. Atmospheric Environment 32(19), 3301-3309.

Smith, K.A., K.E. Dobbie, R. Thorman, C.J. Watson, D.R. Chadwick, S. Yamulki, B.C. Ball, 2012. The effect of $\mathrm{N}$ fertilizer forms on nitrous oxide emissions from UK arable land and grassland. Nutrient Cycling in Agroecosystems 93, 127-149,

Song, A., Fan, F., Yin, C., Wen, S., Zhang, Y., Fan, X. \& Liang, Y., 2017. The effects of silicon fertilizer on denitrification potential and associated genes abundance in paddy soil. Biology and fertility of soils, 53, 627-638.

Souri, M.K., 2010. Effectiveness of Chloride Compared to 3,4-Dimethylpyrazole Phosphate on Nitrification Inhibition in Soil. Communications in Soil Science and Plant Analysis, 41, 1769-1778.

Stehfest, E., Bouwman, L., 2006. N2O and NO emission from agricultural fields and soils under natural vegetation: summarizing available measurement data and modeling of global annual emissions. Nutrient Cycling in Agroecosystems 74. 
Subbarao, G.V., Ito, O., Sahrawat, K.L., Berry, W.L., Nakahara, K., Ishikawa, T., Watanabe, T., Suenaga, K., Rondon, M. \& Rao, I.M., 2006. Scope and Strategies for Regulation of Nitrification in Agricultural Systems-Challenges and Opportunities. Critical Reviews in Plant Sciences, 25, 303-335.

Subbarao, G.V., Kishii, M., Nakahara, K., Ishikawa, T., Ban, T., Tsujimoto, H., George, T.S., Berry, W.L., Hash, C.T. \& Ito, O., 2009. Biological nitrification inhibition (BNI); Is there potential for genetic interventions in the Triticeae? Breeding Science, 59, 529-545.

Subbarao, G.V., Nakahara, K., Ishikawa, T., Ono, H., Yoshida, M., Yoshihashi, T., Zhu, Y., Zakir, H.A.K.M., Deshpande, S.P., Hash, C.T. \& Sahrawat, K.L., 2013. Biological nitrification inhibition (BNI) activity in sorghum and its characterization. Plant and Soil, 366, 243-259.

Subbarao, G.V., O. Ito, K.L. Sahrawat, W.L. Berry, K. Nakahara, T. Ishikawa, T. Watanabe, K. Suenaga, M. Rondon \& I.M. Rao, 2006. Scope and Strategies for Regulation of Nitrification in Agricultural Systems-Challenges and Opportunities, Critical Reviews in Plant Sciences, 25:4, 303-335.

Sun, L., Lu, Y., Yu, F., Kronzucker, H.J. \& Shi, W.C., 2016. Biological nitrification inhibition by rice root exudates and its relationship with nitrogen-use efficiency. New Phytologist, 212, 646-656.

Suter, H.C., Sultana, H., Davies, R., Walker, C. \& Chen, D., 2016. Influence of enhanced efficiency fertilisation techniques on nitrous oxide emissions and productivity response from urea in a temperate Australian ryegrass pasture. Soil Research, 54, 523-532.

Syakila, A. \& Kroeze, C., 2011. The global nitrous oxide budget revisited. Greenhouse Gas Measurement and Management, 1, 17-26.

Torralbo, F., Menéndez, S., Barrena, I., Estavillo, J.M., Marino, D. \& González-Murua, C., 2017. Dimethyl pyrazol-based nitrification inhibitors effect on nitrifying and denitrifying bacteria to mitigate N2O emission. Scientific Reports, 7.

Trenkel, M.E., 2010. Slow- and controlled-release and stabilized fertilizers. An option for enhancing nutrient use efficiency in agriculture, International fertilizer Industry Association Paris.

Treweek, G., Di, H.J., Cameron, K.C. \& Podolyan, A., 2016. Effectiveness of the nitrification inhibitor dicyandiamide and biochar to reduce nitrous oxide emissions. New Zealand Journal of Agricultural Research, 59, 165-173.

Van Burg, P.F.J., Dilz, K. \& Prins, W.H., 1982. Landbouwkundige waarde van verschillende stikstofmeststoffen. Stikstof 100, 518-540.

Bruggen, C. van, A. Bannink, C.M. Groenestein, J.F.M. Huijsmans, H.H. Luesink, S.M. van der Sluis, G.L. Velthof \& J. Vonk, 2017a. Emissies naar lucht uit de landbouw in 2014. Berekeningen met het Nationaal Emissiemodel voor Ammoniak (NEMA) (Emissions to air from agriculture in 2014. Calculations with the National Emissions Model for Ammonia (NEMA)). WOt-technical report 90. WOt Natuur \& Milieu, Wageningen UR (Wot Nature \& Environment, Wageningen UR).

Van Cleemput, O., Vermoesen, A., De Groot, C.J. and van Ryckeghem, K., 1994. Nitrous oxide emission out of grassland. Environ. Monit. Assess. 31, 145-152.

van der Weerden, T.J., Luo, J., Di, H.J., Podolyan, A., Phillips, R.L., Saggar, S., de Klein, C.A.M., Cox, N., Ettema, P. \& Rys, G., 2016. Nitrous oxide emissions from urea fertiliser and effluent with and without inhibitors applied to pasture. Agriculture, Ecosystems and Environment, 219, 58-70.

Van Groenigen, J.W., Kasper, G.J., Velthof, G.L., van den Pol van Dasselaar, A. and Kuikman, P.J., 2004. Nitrous oxide emissions from silage maize fields under different mineral nitrogen fertilizer and manure applications Plant and Soil 263, 101-111

Van Groenigen, J.W., Kuikman, P.J., de Groot, W.K.M. and Velthof, G.L., 2005. Nitrous oxide emission from urine-treated soil as influenced by urine composition and soil physical conditions. Soil Biology and Biochemistry 37, 463-473.

Velthof, G.L., Brader, A.B. and Oenema, O., 1996. Seasonal variations in nitrous oxide losses from managed grasslands in the Netherlands. Plant and Soil 181: 263-274.

Velthof, G.L., Oenema, O., Postma, R. and van Beusichem, M.L., 1997. Effects of type and amount of applied nitrogen fertilizer on nitrous oxide fluxes from intensively managed grassland. Nutrient Cycling in Agroecosystems 46: 257-267.

Velthof, G.L., 2003. Relaties tussen mineralisatie, denitrificatie en indicatoren voor bodemkwaliteit in landbouwgronden. Alterra, Wageningen, Alterra rapport 769, 38 p.

Velthof, G.L., Dolfing, J., Kasper, G.J., van Groenigen, J.W., de Groot, W.J.M., van den Pol-van Dasselaar, A. and Kuikman, P.J., 2003. Beperking van lachgasemissie uit bemeste landbouwgronden. Eindrapport Reductieplan Overige Broeikasgassen Landbouw Cluster 1 Alterra rapport 560.2, $58 \mathrm{pp}$. 
Velthof, G.L., Barot, S., Bloem, J., Butterbach-Bahl, K., Vries, W. de, Kros, J., Lavelle, P., Olesen, J.E., Oenema, O., 2011. Nitrogen as a threat to European soil quality - Chapter 21. In: The European Nitrogen Assessment. Sources, effects and policy perspectives / Sutton, M.A., Howard, C.M., Erisman, J.W., Billen, G., Bleeker, A., Grennfelt, P., Grinsven, H. van, Grizzetti, B., Cambridge : Cambridge University Press, (Nitrogen in Europe) - p. 495 - 510.

Velthof, G.L., Hoving, I.E., Dolfing, J., Smit, A., Kuikman, P.J. and Oenema, O., 2010. Method and timing of grassland renovation affects herbage yield, nitrate leaching, and nitrous oxide emission in intensively managed grasslands. Nutrient Cycling in Agroecosystems 86: 401-412.

Velthof, G.L. and E. Hummelink, 2011. Ammoniak- en lachgasemissie na toediening van mineralenconcentraten. Resultaten van laboratoriumproeven in het kader van de Pilot Mineralenconcentraten. Wageningen, Alterra, Alterra-rapport 2180. 46 blz (In Dutch)

Velthof, G.L. \& J. Mosquera, 2011a. Calculation of nitrous oxide emission from agriculture in the Netherlands. Update of emission factors and leaching fraction. Alterra report 2151. Alterra Wageningen UR, Wageningen, the Netherlands.

Velthof, G.L., Mosquera, J., 2011b. The impact of slurry application technique on nitrous oxide emission from agricultural soils. Agriculture, Ecosystems and Environment 140, 298 - 308.

Verhoeven, E., Pereira, E., Decock, C., Suddick, E., Angst, T. \& Six, J., 2017. Toward a Better Assessment of Biochar-Nitrous Oxide Mitigation Potential at the Field Scale. Journal of Environmental Quality, 46, 237-246.

Vonk, J., S.M. van der Sluis, A. Bannink, C. van Bruggen, C.M. Groenestein, J.F.M. Huijsmans, J.W.H. van der Kolk, L.A. Lagerwerf, H.H. Luesink, S.V. Oude Voshaar \& G.L. Velthof, 2018. Methodology for estimating emissions from agriculture in the Netherlands - update 2018. Calculations of $\mathrm{CH} 4, \mathrm{NH} 3, \mathrm{~N} 2 \mathrm{O}, \mathrm{NOx}, \mathrm{PM} 10, \mathrm{PM} 2.5$ and $\mathrm{CO} 2$ with the National Emission Model for Agriculture (NEMA). Wageningen, The Statutory Research Tasks Unit for Nature and the Environment. WOt-technical report 115. $176 \mathrm{p}$.

Webb, J., Sorensen, P., Velthof, G.L., Amon, B., Pinto, M., Rodhe, L., Salomon, E., Hutchings, N., Burczyk, J., Reid, J.E., 2013. An assessment of the variation of manure nitrogen efficiency throughout Europe and an appraisal of means to increase manure- $\mathrm{N}$ efficiency. Advances in Agronomy 119, 371 - 442.

Webster, C.P. and Dowdell, R.J., 1982. Nitrous oxide emission from permanent grass swards. J. Sci. Food Agric. 33, 227-230.

Weslien, P., Klemedtsson, L., Svensson, L., Galle, B., Kasimir-Klemedtsson, A. and Gustafsson, A., 1998. Nitrogen losses following application of pig manure to arable land. Soil Use and Management 14, 200-208.

Whitmore, A., Dailey, A., Glendining, M., Coleman, K., Powlson, D. \& Goulding, K. A Critical Review of Recent Policy-Relevant Research in Nitrogen Cycling. Final report for project IF0175, 68.

Wolf, J., Beusen, A.H.W., Goenedijk, P., Kroon, T., Rötter, R., van Zeijts, H., 2003. The integrated modeling system STONE for calculating nutrient emissions from agricultures in the Netherlands. Environ Model Software 18:597-617.

Wrage, N., Velthof, G.L., van Beusichem, M.L., Oenema, O., 2001. Role of nitrifier denitrification in the production of nitrous oxide. Soil Biology and Biochemistry 33, 1723-1732.

Wrage-Mönnig, N., M.A. Horn, Reinhard Well, C. Müller, G. Velthof, O. Oenema, 2018. The role of nitrifier denitrification in the production of nitrous oxide revisited, Soil Biology and Biochemistry 123, A3-A16.

Wuebbles, D.J., 2009. Nitrous Oxide: No Laughing Matter. Science 326 (5949), 56-57.

Wulf, S., Maeting, M. and Clemens, J., 2002. Application technique and manure co-fermentation effects on ammonia, nitrous oxide, and methane emissions after spreading: II. Greenhouse gas emissions. J. Environ. Qual. 31, 1795-1801.

Yamulki, S. and Jarvis, S.C., 2002. Short-term effects of tillage and compaction on nitrous oxide, nitric oxide, nitrogen dioxide, methane and carbon dioxide fluxes from grassland. Biol. Fertil. Soils 36, 224-231.

Yamulki, S., Goulding, K.W.T., Webster, C.P. and Harrison, R.M., 1995. Studies on NO and N2O fluxes from a wheat field. Atmospheric Environment 29, 1627-1635.

Yin, S., Zhang, X., Jiang, Z., Zhu, P., Li, C. \& Liu, C., 2017. Inhibitory effects of 3,4-dimethylpyrazole phosphate on $\mathrm{CH} 4$ and $\mathrm{N} 2 \mathrm{O}$ emissions in paddy fields of subtropical China. International Journal of Environmental Research and Public Health, 14. 
Zerulla, W., Barth, T., Dressel, J., Erhardt, K., von Locquenghien, K.H., Pasda, G., Rädle, M. \& Wissemeier, A., 2001. 3, 4-Dimethylpyrazole phosphate (DMPP)-a new nitrification inhibitor for agriculture and horticulture. Biology and fertility of soils, 34, 79-84.

Zhang, M., Fan, C.H., Li, Q.L., Li, B., Zhu, Y.Y. \& Xiong, Z.Q., 2015. A 2-yr field assessment of the effects of chemical and biological nitrification inhibitors on nitrous oxide emissions and nitrogen use efficiency in an intensively managed vegetable cropping system. Agriculture, Ecosystems \& Environment, 201, 43-50. 
Wageningen Environmental Research P.O. Box 47

6700 AA Wageningen

The Netherlands

T +31 (0)317480700

www.wur.nl/environmental-research

Wageningen Environmental Research Report 2921

ISSN 1566-7197
The mission of Wageningen University \& Research is "To explore the potential of nature to improve the quality of life". Under the banner Wageningen University \& Research, Wageningen University and the specialised research institutes of the Wageningen Research Foundation have joined forces in contributing to finding solutions to important questions in the domain of healthy food and living environment. With its roughly 30 branches, 5,000 employees and 10,000 students, Wageningen University \& Research is one of the leading organisations in its domain. The unique Wageningen approach lies in its integrated approach to issues and the collaboration between different disciplines.

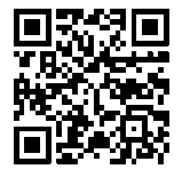





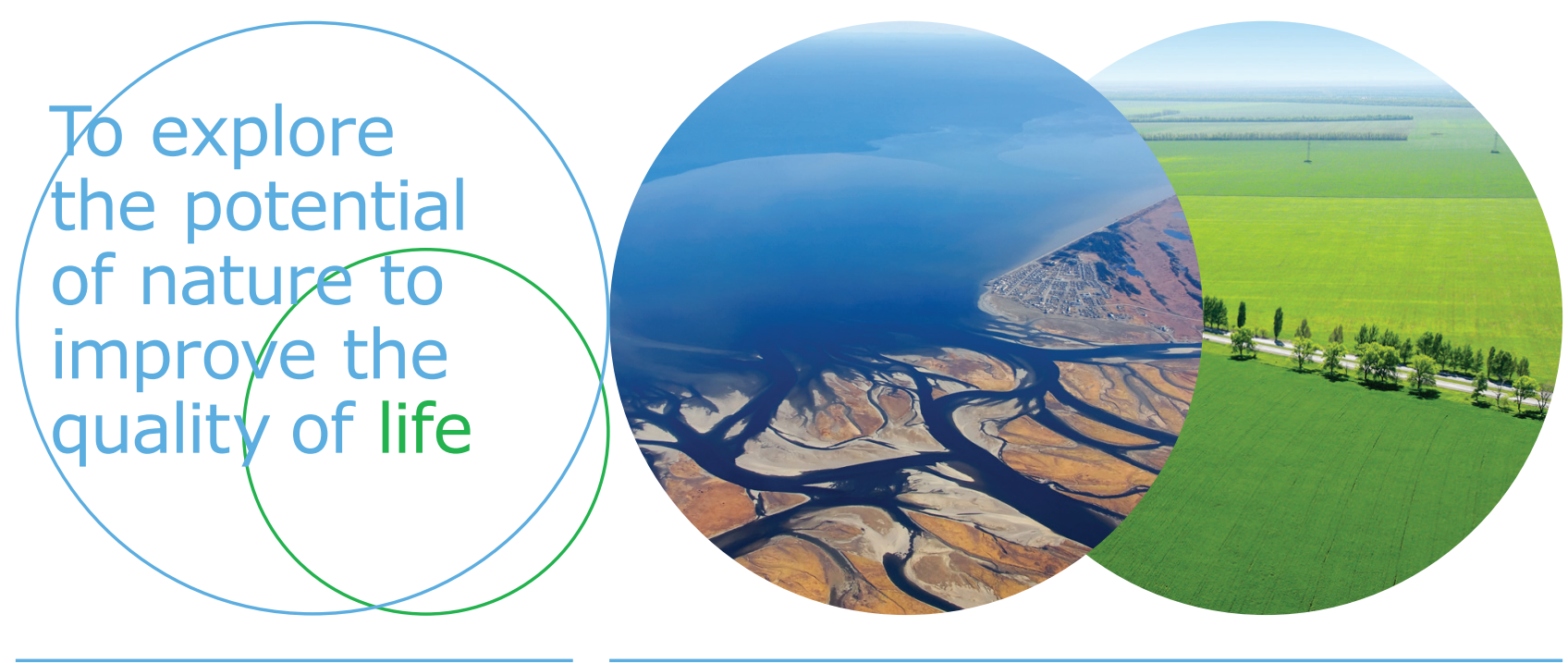

Wageningen Environmental Research P.O. Box 47

$6700 \mathrm{AB}$ Wageningen

The Netherlands

$T+31(0) 317480700$

www.wur.eu/environmental-research

Report 2921

ISSN 1566-7197
The mission of Wageningen University \& Research is "To explore the potential of nature to improve the quality of life". Under the banner Wageningen University \& Research, Wageningen University and the specialised research institutes of the Wageningen Research Foundation have joined forces in contributing to inding solutions to important questions in the domain of healthy food and living environment. With its roughly 30 branches, 5,000 employees and 10,000 students, Wageningen University \& Research is one of the leading organisations in its domain. The unique Wageningen approach lies in its integrated approach to issues and the collaboration between different disciplines. 